DE

M E D I C I N A

T R O P I C A L

$\mathrm{DE}$

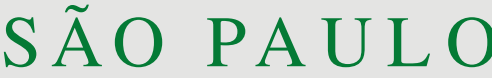

JOURNAL OF THE SÃO PAULO INSTITUTE OF TROPICAL MEDICINE

'Universidade Estadual de Campinas (UNICAMP), Faculdade de Odontologia de Piracicaba, Departamento de Diagnóstico Oral, Laboratório de Microbiologia e Imunologia, Piracicaba, São Paulo, Brazil

${ }^{2}$ Universidade de Alfenas (UNIFENAS), Faculdade de Ciências Médicas \& Centro de Pesquisa em Ciência Animal, Laboratório de Farmacogenética e Biologia Molecular, Alfenas, Minas Gerais, Brazil

Correspondence to: Marcelo Fabiano Gomes Boriollo

Universidade Estadual de Campinas (UNICAMP), Faculdade de Odontologia de Piracicaba, Departamento de Diagnóstico Oral, Laboratório de Microbiologia e Imunologia, Av. Limeira, 901, CEP 13414903, Piracicaba, SP, Brazil

Tel, Fax: +55 19 2106-5250, +55 19 2106$5251,+55192106-5355$

E-mail: marcelofgb@yahoo.com.br

Received: 21 April 2017

Accepted: 18 December 2017

\section{Isoenzymatic genotyping of Staphylococcus aureus from dairy cattle and human clinical environments reveal evolutionary divergences}

\author{
Marcelo Fabiano Gomes Boriollo ${ }^{1,2}$, Rodrigo Carlos Bassi ${ }^{1,2}$, José Francisco \\ Höfling $^{1}$
}

\section{ABSTRACT}

Background: The genetic variability of $610 \mathrm{~S}$. aureus isolates from the hands of professional dentists (A), dental clinic environment air (B), bovine milk from cows with and without mastitis (C), an insufflator for milking equipment (D) and milking environment air (E) was studied by isoenzyme genotyping and genetic and cluster analysis.Results: Monoclonal and polyclonal patterns of $S$. aureus were detected in every bacterial population; however, isolates belonging to the same strain were not found among the populations, suggesting the genetic heterogeneity and the intrapopulation spread of strains. Genetic relationship analysis revealed the co-existence of highly related strains at low frequency among populations. Conclusion: The data suggest that some strains can adapt and colonize new epidemiologically unrelated habitats. Consequently, the occurrence of an epidemiological genotypic identity can assume a dynamic character (spread to new habitats), however infrequently. A tendency of microevolutionary and genetic divergences among populations of $S$. aureus from human sources $(\mathrm{AB})$ and bovine milk (DE), and especially the mammary quarter $(\mathrm{C})$, is also suggested. This research can contribute to the knowledge on the distribution and dissemination of strains and the implementation of control measures and eradication of $S$. aureus in important dental clinic environments, as well as animal environments and dairy production.

KEYWORDS: Staphylococcus aureus. Genetic diversity. Environment and anatomical site. Propagation dynamics. MLEE.

\section{INTRODUCTION}

The dissemination of $S$. aureus is considered a major public health problem because resistant strains can cause serious infections, especially in children and hospitalized patients ${ }^{1,2}$. Dentists treat a wide variety of patients, a fact that exposes these health professionals to people colonized or infected with resistant microorganisms $\mathrm{s}^{3,4}$. The skin, the environment and instruments can be contaminated with saliva, blood or debris during routine dental treatment ${ }^{4,5}$. Several researchers have noted an increase in the amount of microorganisms present during clinical procedures in dental clinic environments, suggesting contamination from aerosols, especially when high-speed devices or ultrasonic scalers are used ${ }^{6,7}$. Among the species identified in microbiological studies, viridans group streptococci (VGS) and Staphylococcus spp. are the most prevalent microorganisms found on the surfaces of dental equipments ${ }^{6-8}$, including methicillin-resistant Staphylococcus aureus (MRSA), which has been detected on dental operatory surfaces, air-water syringes and recliner chairs ${ }^{9}$. 
In animal science, mastitis is considered as one of the most important infectious diseases to occur in dairy cattle herds, causing significant economic loss in every part of the world. S. aureus is an important pathogen associated with bovine mastitis ${ }^{10}$, which spreads mainly within and among cattle animals during milking; udder being the main source of infection. Therefore, control measures are primarily designed to improve hygiene and milking routines, such as milking order and the immersion of teats. Other measures include dairy cattle therapy and proper disposal of infected animals. However, such control measures are not always effective in preventing new infections of $S$. aureus ${ }^{11}$, indicating the complexity of the problem and the possibility of other sources of infection. The probability of udder infections increases if the host has direct contact with reservoirs of pathogens or indirect contact via fomites ${ }^{12}$. Several studies investigating potential reservoirs and fomites of $S$. aureus on dairy properties have been performed ${ }^{13-20}$.

Phenotypic and genotypic methods have allowed researchers to classify isolates of microorganisms in systematic, taxonomic, evolutionary, phylogenetic and epidemiological studies ${ }^{21-23}$. Among these methods, multilocus enzyme electrophoresis (MLEE) has been used for several decades as a standard method to study eukaryotic population genetics ${ }^{24}$ and systematics ${ }^{25}$ as well as largescale studies to estimate the genetic diversity and structure of natural populations of a variety of bacterial species ${ }^{26-29}$ and fungal species including yeasts ${ }^{30-33}$. Results of different studies, with some exceptions ${ }^{34}$, suggest that relatively few clones of $S$. aureus are responsible for the majority of intramammary cattle infections with broad geographical distribution $^{23,35-37}$. Interestingly, the most prevalent clones of bovine mastitis are rarely isolated from humans, suggesting the host specificity of $S$. aureus clones ${ }^{16,35}$. However, Mørk et $a l .^{37}$ observed that common genotypes caused mastitis in cows, goats and dairy sheep, suggesting specificity of anatomical sites rather than host specificity. The distribution of $S$. aureus clones associated with human infections ${ }^{38-41}$ and with bovine mastitis ${ }^{42,43}$ has been characterized and investigated using molecular techniques such as multilocus sequence typing (MLST). Important clonal complexes (CCs) associated with infections by $S$. aureus in human beings ( $\mathrm{CC} 1, \mathrm{CC} 5$ and $\mathrm{CC} 30)$ were also found in isolates from dairy cattle in geographically distinct herds ${ }^{23}$. These observations have suggested the possibility of the transmission of strains between humans and cattle/dairy products, as previously reported ${ }^{42,43}$. Further investigation demonstrated that those $\mathrm{CCs}$ (CC1, CC5 and CC30) were often isolated from asymptomatic carriers or patients with invasive disease ${ }^{38,40,41}$; moreover, it has been suggested that the genetic background of these CCs allows greater capacity to spread among humans ${ }^{40}$. In addition, some of these CCs (CC5 and CC30), corresponding to some of the main epidemic strains of MRSA, are responsible for hospital-acquired MRSA (HA-MRSA) and/or communityacquired MRSA (CA-MRSA) ${ }^{44}$.

The current study evaluated the genetic structure of natural populations of $S$. aureus of environmental, human and bovine origin. The genetic variability within and among populations of $S$. aureus from epidemiologically (i.e., professional dentists, dental clinic environment, bovine milk, insufflator and milking environment) and geographically (i.e., Alfenas and Passos cities, MG, Brazil) related and unrelated strains, the frequency of occurrence of strains and operational taxonomic groups (taxon and cluster) and possible epidemiological correlations were investigated by using isoenzymatic markers (MLEE), as well as genetic and grouping analysis.

\section{MATERIALS AND METHODS}

\section{Microbiological sampling}

This research was conducted in the Laboratory of Pharmacogenetics and Molecular Biology, Faculty of Medical Sciences and Center for Research in Animal Science, University of Alfenas, Alfenas city, MG, Brazil. A total of 610 bacterial isolates of oxacillin-resistant (ORSA) and oxacillin-sensitive S. aureus (OSSA), belonging to the bacteria collection of the laboratory, were kindly provided and used for the present study. These samples were previously isolated (culture medium - Mannitol salt phenol red agar) from the $(i)$ hands of professional dentists (Population A: $n=132$ ORSA and OSSA; Dental clinics, School of Dentistry, University of Alfenas, Alfenas city, MG, Brazil), (ii) dental clinic environment air (Population B: $n=272^{\circ}{ }^{\text {ORSA }}$ and OSSA; Dental clinics, School of Dentistry, University of Alfenas, Alfenas city, MG, Brazil), (iii) bovine milk from cows with and without mastitis (Population C: $n=31$ ossA, being 16 sampling coming from cows with mastitis; Dairy Farm, Passos city, MG, Brazil), (iv) an insufflator for milking equipment (Population D: $n=24$ ossA; Dairy Farm, Passos city, MG, Brazil) and (v) milking environment air (Population E: $n=151$ ossa; Dairy Farm, Passos city, MG, Brazil), and characterized by microbiological methods of identification (Gram staining, growth on chromogenic medium CHROMagar Staphylococcus aureus ${ }^{\circledR}$, biochemical tests such as catalase test, coagulase test [Coagu-Plasma, Laborclin Produtos para Laboratórios Ltda.], clumping factor A test [Staphy Test, Probac do Brasil Produtos Bacteriológicos Ltda., Marnes La Coquette, France], mannitol fermentation test, DNAse test and Voges-Proskauer 
test) ${ }^{6,45}$ and antimicrobial susceptibility testing (by disk diffusion method $)^{46,47}$ and confirmatory screening for resistance to oxacillin ${ }^{48}$.

\section{Enzyme extraction}

Bacterial cultures were grown in flasks containing $200 \mathrm{~mL}$ of BHI (Brain Heart Infusion) at $35^{\circ} \mathrm{C}$ for $24 \mathrm{~h}$ under constant shaking at $150 \mathrm{rpm}$ (Shaker Incubator mod. NT 712, Nova Técnica Instrumentos e Equipamentos de Laboratório Ltda.). After growth, cells were centrifuged at $5,000 \times g$ for $3 \mathrm{~min}$ and washed twice in sterile $40 \mathrm{mM}$ PBS (pH 7.5), submitting each wash to the same centrifugal force. Pellets $(\sim 250 \mu \mathrm{L})$ were transferred to 2-mL microtubes (Biospec Products, Inc.) containing cold PBS (approximately $8^{\circ} \mathrm{C}$ ) and glass beads $(0.45-0.55 \mathrm{~mm})$ (1:1:1). These mixtures were kept on ice $\left(4{ }^{\circ} \mathrm{C}\right)$ for $5 \mathrm{~min}$ and agitated 4 times in a BeadBeater machine (Biospec Products, Inc., Bartlesville, OK, USA) at 4,200 rpm for $30 \mathrm{~s}$, at one-minute intervals. Cell fragments were centrifuged at $5,000 \times g$ at $4{ }^{\circ} \mathrm{C}$ for $5 \mathrm{~min}$ (Eppendorf 5403, rotor $16 \mathrm{~F} 24-11)$. The resulting upper aqueous phase was applied to Whatman $\mathrm{n} 3$ filter papers (wicks), $12 \times 5 \mathrm{~mm}$ in size, and maintained at $-70{ }^{\circ} \mathrm{C}$ until time of use $\mathrm{e}^{21,27,31-33}$.

\section{Electrophoresis and specific enzyme staining}

The enzymes were separated in 13\% (wt/vol) starch gels (dimensions $200 \times 120 \times 10 \mathrm{~mm}$; Penetrose $30^{\circledR}$; Refinações de Milho Brasil Ltda.) in Tris-citrate buffer $\mathrm{pH} 8.0$ (electrode buffer diluted 1:29). The wicks were then immediately soaked in $5 \mu \mathrm{L}[0.02 \%(\mathrm{wt} / \mathrm{vol})]$ of bromophenol-blue solution and then perpendicularly applied to a longitudinally cut gel $(20 \mathrm{~mm})$. Electrophoresis was performed in a horizontal and continuous system at 130 volts at $4{ }^{\circ} \mathrm{C}$ overnight (bromophenol-blue migration equivalent to $80 \mathrm{~mm}$ ) using Tris-citrate electrode buffer $(\mathrm{pH} 8.0)$. To assure reproducible results (i.e., the percentage of strains that give the same result on repeated testing), S. aureus ATCC $^{\circledR} 29213$ enzymes were included in each gel. After electrophoresis, gels were put on an acrylic base and sliced into 1.5-mm sections with the aid of rulers and \#15 nylon strings. The sections were carefully placed inside white porcelain containers and stained for 10 enzymes ${ }^{21,31-33}$. The enzymatic activities that were analyzed included: alcohol dehydrogenase (EC 1.1.1.1), sorbitol dehydrogenase (EC 1.1.1.14), mannitol-1-phosphate dehydrogenase (EC 1.1.1.17), malate dehydrogenase (EC 1.1.1.37), glucose dehydrogenase (EC 1.1.1.47), D-galactose dehydrogenase (EC 1.1.1.48), glucose-6-phosphate dehydrogenase (EC 1.1.1.49), catalase (EC 1.11.1.6), and $\alpha$ - and $\beta$-esterase (EC 3.1.1.1.) (Table 1).

\section{Genetic interpretation of the MLEE patterns}

Pattern interpretation was performed following the general rules commonly accepted in the deduction of allelic composition for haploid organisms. The bands on the gels were numbered in order of decreasing mobility, and their corresponding alleles were numbered by using the same nomenclature. A lack of demonstrable activity for an enzyme was scored as one null allele at the corresponding gene locus. Each unique combination of alleles over the enzyme loci examined resulted in an electrophoretic type (ET) - subtype or strain. The percentage of polymorphic loci, the average number of alleles per locus and the average number of alleles per polymorphic locus were also determined ${ }^{21,31-33}$.

\section{Discriminatory power}

The discriminatory power of the MLEE method based on genetic interpretation of the electrophoretic patterns was established by the numerical index of discrimination $(D)$, according to the probability that two unrelated isolates sampled from the test population will be classified into different types (i.e., strains or ETs) (1,33 $^{31}$. This probability can be calculated by Simpson's index of diversity, which was developed for the description of species diversity within an ecological habitat ${ }^{49}$. This index can be derived from an elementary probability theory ${ }^{50}$ and is given by the following equation: $D=1-\frac{1}{N(N-1)} \sum n_{j}\left(n_{j}-1\right)$, where $N$ is the total number of isolates in the sample population, $S$ is the total number of types (strains) described, and $n_{j}$ is the number of isolates belonging to the $j^{\text {th }}$ type. This equation was derived as follows. The probability that two isolates sampled consecutively will belong to that type is: $\frac{n_{j}\left(n_{j}-1\right)}{N(N-1)}$. These probabilities can be summed for all the described types to determine the probability that any two consecutively sampled isolates will be the same type. This sum can be subtracted from 1 to obtain the equation above. This equation can be applied both to a direct comparison of the discriminating power of typing methods and to analysis of the discriminating power of combined typing schemes. An index of greater than 0.90 would be desirable if the typing results are to be interpreted with confidence $e^{51,52}$.

\section{Grouping and genetic diversity analysis}

The statistical methods of $\mathrm{Ne}^{53}$ were used to estimate the genetic distance among the isolates and/or strains (ETs) 
Table 1 - Systems and solutions utilized for the MLEE analyses of the $S$. aureus metabolic enzymes

\begin{tabular}{|c|c|c|c|c|c|c|c|}
\hline \multicolumn{3}{|c|}{ Enzyme } & \multicolumn{5}{|c|}{ Compound for staining } \\
\hline $\begin{array}{c}\text { EC } \\
\text { number }\end{array}$ & Name & Symbol & Substrate & Buffer & Salt & Coenzyme & Dye and Catalyser \\
\hline 1.1.1.1. & $\begin{array}{c}\text { alcohol } \\
\text { dehydrogenase }\end{array}$ & $\mathrm{ADH}$ & $\begin{array}{l}\text { Ethanol }(3 \mathrm{~mL}) \\
\text { Isopropanol } \\
(2 \mathrm{~mL})\end{array}$ & $\begin{array}{c}200 \mathrm{mM} \\
\text { Tris-HCl pH } 8.0 \\
{\text { (q.s.p. } 50 \mathrm{~mL})^{\mathrm{a}}}^{\text {a }}\end{array}$ & & $\begin{array}{l}\text { NAD } 1 \% \\
(2 \mathrm{~mL})\end{array}$ & $\begin{array}{l}\text { PMS 1\% (500 } \mu \mathrm{L}) \\
\text { MTT } 1.25 \%(1 \mathrm{~mL})\end{array}$ \\
\hline 1.1.1.17 & $\begin{array}{c}\text { mannitol-1- } \\
\text { phosphate } \\
\text { dehydrogenase }\end{array}$ & M1P & $\begin{array}{c}\text { Mannitol } \\
\text { 1-phosphate } \\
(5 \mathrm{mg})\end{array}$ & 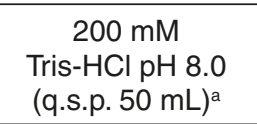 & & $\begin{array}{l}\text { NAD } 1 \% \\
(2 \mathrm{~mL})\end{array}$ & $\begin{array}{l}\text { PMS 1\% (500 } \mu \mathrm{L}) \\
\text { MTT 1.25\% (1 mL) }\end{array}$ \\
\hline 1.1.1.37. & $\begin{array}{c}\text { malate } \\
\text { dehydrogenase }\end{array}$ & $\mathrm{MDH}$ & $\begin{array}{l}\text { 2M Malic acid } \\
\qquad(6 \mathrm{~mL})^{\mathrm{b}}\end{array}$ & $\begin{array}{c}200 \mathrm{mM} \\
\text { Tris-HCl pH } 8.0 \\
\text { (q.s.p. } 50 \mathrm{~mL})^{\mathrm{a}}\end{array}$ & & $\begin{array}{l}\text { NAD } 1 \% \\
(2 \mathrm{~mL})\end{array}$ & $\begin{array}{l}\text { PMS 1\% (500 } \mu \mathrm{L}) \\
\text { MTT 1.25\% (1 mL) }\end{array}$ \\
\hline 1.1.1.47 & $\begin{array}{c}\text { glucose } \\
\text { dehydrogenase }\end{array}$ & $\mathrm{GDH}$ & $\begin{array}{l}\text { D-glucose } \\
(500 \mathrm{mg})\end{array}$ & $\begin{array}{c}200 \mathrm{mM} \\
\text { Tris- } \mathrm{HCl} \mathrm{pH} 8.0 \\
\text { (q.s.p. } 50 \mathrm{~mL})^{\mathrm{a}}\end{array}$ & & $\begin{array}{l}\text { NAD } 1 \% \\
(2 \mathrm{~mL})\end{array}$ & $\begin{array}{l}\text { PMS 1\% (500 } \mu \mathrm{L}) \\
\text { MTT } 1.25 \%(1 \mathrm{~mL})\end{array}$ \\
\hline 1.1.1.48 & $\begin{array}{c}\text { D-galactose } \\
\text { dehydrogenase }\end{array}$ & GLDH & $\begin{array}{l}\text { Galactose } \\
(450 \mathrm{~mL})\end{array}$ & 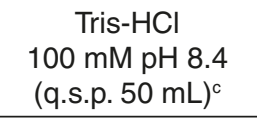 & & $\begin{array}{l}\text { NAD } 1 \% \\
(1 \mathrm{~mL})\end{array}$ & $\begin{array}{l}\text { PMS 1\% (500 } \mu \mathrm{L}) \\
\text { MTT } 1.25 \%(1 \mathrm{~mL})\end{array}$ \\
\hline 1.1.1.49 & $\begin{array}{c}\text { glucose-6- } \\
\text { phosphate } \\
\text { dehydrogenase }\end{array}$ & G6PDH & $\begin{array}{c}\text { Glicose-6- } \\
\text { phosphate } \\
\text { disodium salt } \\
(100 \mathrm{mg})\end{array}$ & $\begin{array}{c}200 \mathrm{mM} \\
\text { Tris- } \mathrm{HCl} \mathrm{pH} 8.0 \\
\text { (q.s.p. } 50 \mathrm{~mL})^{\mathrm{a}}\end{array}$ & $\begin{array}{l}100 \mathrm{mM} \\
\mathrm{MgCl}^{2} \\
(1 \mathrm{~mL})^{\mathrm{d}}\end{array}$ & $\begin{array}{l}\text { NADP } 1 \% \\
(1 \mathrm{~mL})\end{array}$ & $\begin{array}{l}\text { PMS 1\% (500 } \mu \mathrm{L}) \\
\text { MTT } 1.25 \%(1 \mathrm{~mL})\end{array}$ \\
\hline 1.11.1.6 & catalase & $\mathrm{CAT}^{\mathrm{e}}$ & & & & & \\
\hline 3.1.1.1. & $\begin{array}{c}\alpha \text { - and } \\
\beta \text {-esterase }\end{array}$ & EST & $\begin{array}{c}\alpha-\text { and } \beta- \\
\text { Naphthyl acetate } \\
(1 \% \text { solution in } \\
\text { acetone })(1.5 \mathrm{ml})\end{array}$ & $\begin{array}{l}\text { 50mM Sodium } \\
\text { phosphate pH } 6.0 \\
(\text { q.s.p. } 50 \mathrm{~mL})^{\dagger}\end{array}$ & & & $\begin{array}{l}\text { Fast Blue RR salt } \\
\qquad(25 \mathrm{mg})\end{array}$ \\
\hline
\end{tabular}

Electrode buffer:Tris-citrate $\mathrm{pH} 8.0$ [83.2 $\mathrm{g}_{\text {of }} \mathrm{C}_{4} \mathrm{H}_{11} \mathrm{NO}_{3}$ (Tris), $33.09 \mathrm{~g}$ of $\mathrm{C}_{6} \mathrm{H}_{8} \mathrm{O}_{7} \cdot \mathrm{H}_{2} \mathrm{O}$ (Citric acid), $1 \mathrm{~L}$ of $\mathrm{H}_{2} \mathrm{O}$ ]; Gel buffer: Electrode buffer diluted 1:29. ${ }^{\text {a }} 24.2 \mathrm{~g}$ of $\mathrm{C}_{4} \mathrm{H}_{11} \mathrm{NO}_{3}$ (Tris), $1 \mathrm{~L}$ of $\mathrm{H}_{2} \mathrm{O}\left(\mathrm{pH}\right.$ adjusted with $\mathrm{HCl}$ ); ${ }^{\text {b }} 26.8 \mathrm{~g}$ of $\mathrm{C}_{4} \mathrm{H}_{6} \mathrm{O}_{5}$ (DL-malic acid) and $16 \mathrm{~g}$ of $\mathrm{NaOH}$ in $0.1 \mathrm{~L}$ of $\mathrm{H}_{2} \mathrm{O}$ (caution: potentially explosive reaction); ${ }^{\mathrm{c}} 12.1 \mathrm{~g}$ of $\mathrm{C}_{4} \mathrm{H}_{11} \mathrm{NO}_{3}$ (Tris), $1 \mathrm{~L}$ of $\mathrm{H}_{2} \mathrm{O}$ ( $\mathrm{pH}$ adjusted with $\mathrm{HCl}$ ); ${ }^{\text {d }} 2.03 \mathrm{~g}$ of $\mathrm{MgCl}_{2} \cdot 6 \mathrm{HCl}$ (Magnesium chloride) in $0.1 \mathrm{~L}$ of $\mathrm{H}_{2} \mathrm{O}$; e Incubate gel slice for 30 min at $0{ }^{\circ} \mathrm{C}$ in $50 \mathrm{~mL}$ of $0.1 \mathrm{M}$ sodium phosphate $\mathrm{pH} 7.0$ buffer, then pour off solution, and immerse it in $50 \mathrm{~mL}$ of $1.5 \%$ potassium iodide solution (KI) for 2 min. Therefore, rinse gel slice with water, and immerse it in $50 \mathrm{~mL}$ of $0.03 \%$ hydrogen peroxide $\left(\mathrm{H}_{2} \mathrm{O}_{2}\right)$ solution. Mix gently and remove stain solution when white zones appear on dark-blue background; ${ }^{\dagger}$ Sodium phosphate buffer pH 7.0: mix equal parts of $27.6 \mathrm{~g}$ of $\mathrm{NaH}_{2} \mathrm{PO}_{4} \cdot \mathrm{H}_{2} \mathrm{O}$ (monobasic) in $1 \mathrm{~L}$ of water and $53.6 \mathrm{~g}$ of $\mathrm{Na}_{2} \mathrm{HPO}_{4} \cdot 7 \mathrm{H}_{2} \mathrm{O}$ in $1 \mathrm{~L}$ of water, then dilute the mixture 1:25 with water.

of each population of oxacillin-resistant and/or oxacillin-

sensitive $S$. aureus: $d_{i j}=-\operatorname{In}(I)$ or $d_{i j}=-\operatorname{In}\left[\frac{\sum_{k}\left|x_{k i} x_{k j}\right|}{\sqrt{\sum_{k} x_{k i}^{2} x_{k j}^{2}}}\right]$, where $I$ is the normalized identity of genes among two populations (ranging from 0 to infinity), a measure of genetic distance based on the identity of genes (frequency of alleles for all loci, including monomorphic loci) among populations. This genetic distance measures the accumulated allelic differences per locus, which can also be estimated from the amino acid sequences of proteins and even for a distantly related species. As a consequence, if enough data are available, the genetic distances among any pair of organisms can be measured in terms of $d_{i j}$. In addition, this measure can be applied to any kingdom of organism regardless of the level of ploidy or mating scheme. Its interpretation in terms of enzyme loci infers that, on average, zero to an infinite number of allelic substitutions are detected (by electrophoresis) in every 100 loci from a common ancestral strain ${ }^{31-33,53,54}$.

Dendrograms were generated using the SAHN grouping method (Sequential, Agglomerative, Hierarchic, Nonoverlapping Clustering Methods) and the UPGMA algorithm (Unweighted Pair-Group Method Using an Arithmetic Average), based on their respective matrix $d_{i j}{ }^{55}$. Once MLEE provides all levels of relatedness, which must be resolved by DNA fingerprinting (i.e., identifying the same strain in independent isolates, identifying microevolutionary changes in a strain, identifying clusters of moderately related isolates and identifying completely unrelated isolates), a threshold (average value: $\bar{d}_{i j}$ ) was established in the dendrograms to identify clusters of identical isolates and highly related isolates $\left(0 \leq d_{i j}<\bar{d}_{i j}\right)$ and $\operatorname{taxa}\left(d_{i j} \geq \overline{d_{i j}}\right)^{31,33,54,55}$. 
The Pearson product-moment correlation coefficient (rangingfrom-1 to+1), $r_{j k}=\frac{\sum_{i=1}^{n}\left(X_{i j}-\overline{X_{j}}\right)\left(X_{i k}-\overline{X_{k}}\right)}{\sqrt{\sum_{i=1}^{n}\left(X_{i j}-\overline{X_{j}}\right)^{2} \sum_{i=1}^{n}\left(X_{i k}-\overline{X_{k}}\right)^{2}}}$, [where $X_{i j}$ stands for the character state value of character $i$ in OTU (Operational Taxonomy Unit) $j, X_{j}$ is the mean of all state values for OTU $j$, and $n$ is the number of characters sampled], was used as a measure of the agreement between the genetic distance values implied by the UPGMA dendrograms and the ones from the original genetic distance matrices $d_{i j}$. These agreements were interpreted as follows: $0.9 \leq r_{j k}$, very good fit; $0.8 \leq r_{j k}<0.9$, good fit; $0.7 \leq r_{j k}<0.8$, poor fit; $r_{j k}<0.7$, very poor fit. All of these analyses were obtained using the NTSYS-pc 2.1 program $^{55}$.

An additional index was used as a measure of genetic diversity of bacterial isolates, as proposed by $\mathrm{Nei}^{56}$, which employs the genic frequencies (allele frequencies). This index allows hierarchical partition of diversity in its components "between" and "within" the experimental units. The unit may be the species or a large population constituted by several subpopulations or demes. Several hierarchical levels can be determined from the following formula: $H_{T}=1-\sum \bar{P}^{2}$, where $H_{T}$ and $\bar{P} i$ correspond to the total diversity of species, considering a single locus and the average frequency of allele $i$ at a given locus in the species as a whole (averaged over populations). The total diversity $\left(H_{T}\right)$ is constituted by $H_{T}=H_{S}+D_{S T}$, where $H_{S}$ and $D_{S T}$ correspond to the component of diversity "within" populations and the component "between" populations, respectively, within the species (population) considered. In turn, the diversity genetic proportion given to the component "between" populations is estimated by the following equation: $G_{S T}=\frac{D_{S T}}{H_{T}}$. However, when considering multiple loci, the total diversity $\left(H_{T}\right)$ of species (population) is calculated using the arithmetic average of the values estimated for each locus separately ${ }^{56}$.

\section{RESULTS}

\section{Genetic interpretation of the MLEE patterns}

The isoenzymatic patterns of each population of oxacillin-resistant and/or oxacillin-sensitive $S$. aureus, including the type strain ATCC $^{\circledR} 25923$, were reproducible in different gels after three repetitions of each electrophoretic run (i.e., the reproducibility was excellent for the replicate samples: $\geq 95 \%$ ). According to the haploid nature of $S$. aureus, these patterns demonstrated the following characteristics (Supplemental Table 1):
Population A (hands of professional dentists ${ }^{n}=132$ ):

- Number of polymorphic loci: 34 (94.4\%).

- Average number of alleles per locus: 1.861 .

- Average number of alleles per polymorphic locus: 1.750 .

- Electrophoretic types (ET): 127 strain (95.4\% of total isolates).

- Discriminatory power: 0.99895 , that is, $99.895 \%$ probability that two unrelated $S$. aureus isolates sampled from the test population will be classified in different strains.

- Clonality patterns: Monoclonal and polyclonal.

Population B (dental clinic environment air ${ }^{n=272}$ ):

- Number of polymorphic loci: 43 (90.7\%).

- Average number of alleles per locus: 3.00 .

- Average number of alleles per polymorphic locus: 2.02.

- Electrophoretic types (ET): 235 strain (86.4\% of total isolates).

- Discriminatory power: 0.99688 , that is, $99.688 \%$ probability that two unrelated $S$. aureus isolates sampled from the test population will be classified in different strains.

- Clonality patterns: Monoclonal and polyclonal.

Population C (bovine milk from cows with and without mastitis ${ }^{n=31}$ ):

- Number of polymorphic loci: 36 (100\%).

- Average number of alleles per locus: 1.527.

- Average number of alleles per polymorphic locus: 1.527.

- Electrophoretic types (ET): 22 strain (70.9\% of total isolates).

- Discriminatory power: 0.96559 , that is, $96.559 \%$ probability that two unrelated $S$. aureus isolates sampled from the test population will be classified in different strains.

- Clonality patterns: Monoclonal and polyclonal.

Population D (an insufflator for milking equipment ${ }^{n=24}$ ):

- Number of polymorphic loci: 23 (100\%).

- Average number of alleles per locus: 1.130.

- Average number of alleles per polymorphic locus: 1.130.

- Electrophoretic types (ET): 23 strain (95.8\% of total isolates).

- Discriminatory power: 0.99637 , that is, $99.637 \%$ probability that two unrelated $S$. aureus isolates sampled from the test population will be classified in different strains.

- Clonality patterns: Monoclonal and polyclonal.

Population E (milking environment air ${ }^{n=151}$ ):

- Number of polymorphic loci: 47 (92.2\%). 
- Average number of alleles per locus: 2.274.

- Average number of alleles per polymorphic locus: 1.882

- Electrophoretic types (ET): 144 strain (95.3\% of total isolates).

- Discriminatory power: 0.99947 , that is, $99.947 \%$ probability that two unrelated $S$. aureus isolates sampled from the test population will be classified in different strains.

- Clonality patterns: Monoclonal and polyclonal.

Total Population $(n=610)$ :

- Number of polymorphic loci: 51 (92.7\%).

- Average number of alleles per locus: 3.652.

- Average number of alleles per polymorphic locus: 2.200.

- Electrophoretic types (ET): 553 strain (90.3\% of total isolates).

- Discriminatory power: 0.999 , that is, $99.9 \%$ probability that two unrelated $S$. aureus isolates sampled from the test population will be classified in different strains.

- Clonality patterns: Monoclonal and polyclonal.

\section{Grouping and genetic diversity analysis}

The genetic diversity of 610 isolates of $S$. aureus from 5 different populations (Populations $\mathrm{A}^{n=132}, \mathrm{~B}^{n=272}, \mathrm{C}^{n=31}$, $\mathrm{D}^{n=24}$ and $\mathrm{E}^{n=151}$ ) and different geographic areas (Alfenas and Passos cities, Minas Gerais state, Brazil) was analyzed using Nei's distance ${ }^{53}$ and an UPGMA dendrogram (Supplemental Figure 1). The genetic diversity of the total bacterial population ranged from 0 to 0.3810 ; that is, on average, the population of isolates contained from 0 to 38.1 allelic substitutions for each 100 loci, starting from a common ancestor. Taking into consideration the average genetic distance $\left(\bar{d}_{i j}=0.0551 \pm 0.0624\right)$ obtained from the total population of bacteria, these analyses also permitted the verification of the coexistence (threshold: $0.0551>d_{i j} \geq 0$ - identical or highly related isolates/strains) or non-coexistence (thresholds: $0.1175>d_{i j} \geq 0.0551-$ moderately related isolates/strains; $d_{i j} \geq 0.1175$ - isolates/ strains unrelated or genetically related to distance) of strains among the bacterial populations and the inference of possible propagation among them or microevolutionary alterations and better adaptations.

Eighty highly polymorphic taxa (of I out LXXX) were identified from the $d_{i j}$ value over 0.1175 (taxa genetically related to distance). Then, moderately related isolates/strains or clusters $\left(0.1175 \geq d_{i j}>0.0551\right)$ were identified within each of these large taxa. A total of 91 clusters $\left(d_{i j}=0.0551\right)$ distributed in these taxa was also identified. Each cluster comprised two or more bacterial isolates interpreted as identical or highly related isolates (strains) $\left(0.0551>d_{i j} \geq 0\right)$. The interpretation of the UPGMA dendrogram and, consequently, the qualitative distribution (i.e., epidemiological characteristic of each bacterial population) and quantitative distribution of these isolates/strains and clusters of each taxon, are shown in the Supplemental Table 2.

The genetic diversity proposed by $\mathrm{Nei}^{56}$, which enables the hierarchical partition of diversity into its components "between" and "within" the experimental units, was also determined for bacterial isolates from each of the 5 populations (A, B, C, D and E). The heterozygosity for each enzyme locus was determined in these populations. The total diversity $\left(H_{T}\right)$ was calculated from the arithmetic averages of the values estimated for the loci existing between paired populations. The values $\left(H_{T}\right)$ ranged between 0.8642 and 0.9565 in ten pairings [i.e., A versus $\mathrm{B}\left(H_{T}=0.9319\right)$, A versus $\mathrm{C}\left(H_{T}=0.8950\right)$, A versus $\mathrm{D}\left(H_{T}=0.8642\right)$, A versus $\mathrm{E}\left(H_{T}=0.9499\right)$, B versus $\mathrm{C}\left(H_{T}=0.9527\right)$, B versus $\mathrm{D}\left(H_{T}=0.9485\right)$, B versus $\mathrm{E}\left(H_{T}=0.9547\right)$, C versus $\mathrm{D}\left(H_{T}=0.9077\right), \mathrm{C}$ versus $\mathrm{E}\left(H_{T}=0.9565\right)$ and $\mathrm{D}$ versus $\left.\mathrm{E}\left(H_{T}=0.9424\right)\right]$. The components of diversity "within" $\left(H_{S}\right)$ and "between" $\left(D_{S T}\right)$ bacterial populations and the genetic diversity that is assigned to the component "between" populations $\left(G_{S T}\right)$ were then determined. These results revealed indices of total genetic variability of $0.1 \%, 2.5 \%, 1.8 \%, 2.5 \%, 0.6 \%, 0.3 \%, 0.1 \%, 4.1 \%$, $1.1 \%$ and $0.0 \%$ attributable to differences "between" populations $\mathrm{A}$ versus $\mathrm{B}, \mathrm{A}$ versus $\mathrm{C}, \mathrm{A}$ versus $\mathrm{D}, \mathrm{A}$ versus $\mathrm{E}$, $\mathrm{B}$ versus $\mathrm{C}, \mathrm{B}$ versus $\mathrm{D}, \mathrm{B}$ versus $\mathrm{E}, \mathrm{C}$ versus $\mathrm{D}, \mathrm{C}$ versus $\mathrm{E}$ and $\mathrm{D}$ versus $\mathrm{E}$, respectively, whereas the total genetic variability present "within" these populations was $99.9 \%$, $97.5 \%, 98.2 \%, 97.5 \%, 99.4 \%, 99.7 \%, 99.9 \%, 95.9 \%$, $98.9 \%$ and $100 \%$, respectively. Such variability can also be observed in the UPGMA dendrogram generated from the matrix of genetic variability ${ }^{56}$ attributable to differences "between" populations (Figure 1).

\section{DISCUSSION}

\section{Inter and intrapopulation clonality of S. aureus}

In this study, the isoenzymatic electrophoresis profiles of $S$. aureus isolates from five distinct populations (A, $\mathrm{B}, \mathrm{C}, \mathrm{D}$ and $\mathrm{E}$ ) were reproducible in three replicates of electrophoretic tests $(\geq 95 \%)$. The high discriminatory power of MLEE (0.965-0.999) proves it to be a powerful and reliable tool for typing $S$. aureus in epidemiological studies (Supplemental Table 1). The reported results for the reproducibility and discriminatory power of MLEE accord with those previously reported in studies of medical relevance ${ }^{21,26,27,30}$; however, the discriminatory power 
Population C

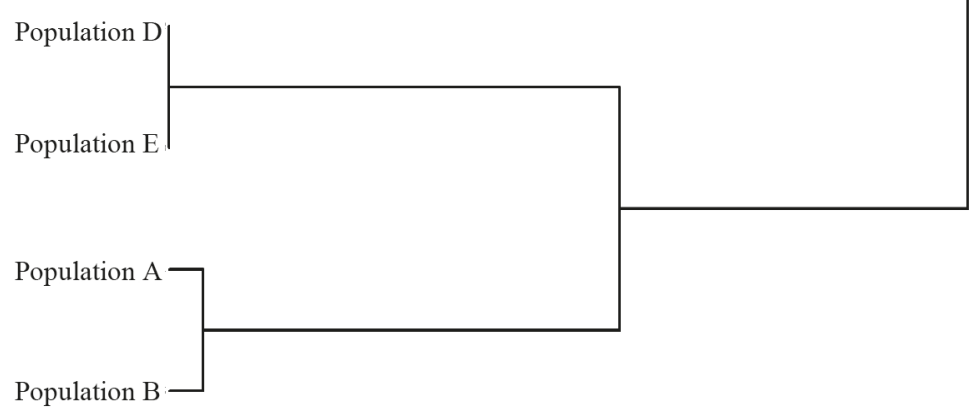

Genetic variability attributable to differences (\%) "between" bacterial populations.

\begin{tabular}{l|lllll}
\multicolumn{1}{c}{$\mathrm{A}$} & $\mathrm{B}$ & $\mathrm{C}$ & $\mathrm{D}$ & $\mathrm{E}$ \\
\cline { 2 - 6 } $\mathrm{A}$ & - & & & & \\
$\mathrm{B}$ & 0.090 & - & & & \\
$\mathrm{C}$ & 2.512 & 0.628 & - & & \\
$\mathrm{D}$ & 1.792 & 0.266 & 4.056 & - & \\
$\mathrm{E}$ & 2.482 & 0.134 & 1.080 & 0.000 & -
\end{tabular}

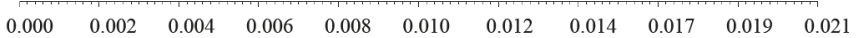

Figure 1 - Total genetic variability attributable to differences "between" bacterial populations of $S$. aureus from the hands of professional dentists (A), from dental clinic environment air (B), from bovine milk from cows with and without mastitis (C), from an insufflator for milking equipment (D) and from milking environment air (E). UPGMA dendrogram generated from the genetic diversity matrix ${ }^{56}$

described in this research was greater than those reported by other groups of researchers ${ }^{36,57}$.

S. aureus is a heterogeneous bacterium (polymorphic) ${ }^{58}$ with a clonal population structure ${ }^{40}$. Consequently, it is believed that $S$. aureus does not undergo extensive recombination, diversifies in large part by nucleotide mutations and displays a high degree of linkage disequilibrium (non-random associations among genic loci). In this study, qualitative and quantitative variations of polymorphic loci, average number of alleles per locus and average number of polymorphic alleles of $S$. aureus were observed across all 5 populations sampled. These variations have been observed in several studies of genetic diversity of $S$. aureus populations from human and bovine sources $^{35,36,57-59}$. In addition, the identification of $S$. aureus strains in each population revealed polyclonal and monoclonal patterns within the populations. However, no monoclonal pattern was observed between the populations (A, B, C, D and E). These data suggest a high genetic diversity of $S$. aureus in every bacterial population studied (i.e., intrapopulation genetic heterogeneity) and among them, even without any correlation of interpopulation monoclonality. Specific and limited patterns of spread and transmission of $S$. aureus were also suggested to occur in every bacterial population. The evidence of interpopulation monoclonality and interpopulation polyclonality of $S$. aureus has been reported previously. Strains of $S$. aureus toxin 1 producers (Toxic Shock Syndrome - TSS) from ovine sources were genotypically characterized ( $t$ st gene) and considered distinct from those clones associated with cases of TSS in humans (approximately 90\%), suggesting that allele differences exist (structural tst gene) among strains recovered from different host species ${ }^{60}$.
The host specificity among $S$. aureus clones was also demonstrated ${ }^{61,62}$. An extensive study from 2.077 $S$. aureus isolates from humans, cows and sheep revealed considerable genetic diversity among strains and found that most of the 252 identified clones were preferentially associated with a single species of host, whereas only 6 of 33 clonal strains were shared among cattle and humans. These results suggested that the ability of the bacterium to colonize humans or cows evolved several times during the differentiation of $S$. aureus populations and provided strong evidence for host specificity among clones ${ }^{62}$. The concept of host specialization among $S$. aureus strains is also reinforced by the fact that certain bacterial clones are predominantly associated with certain hosts, in other words, humans or animals (dairy cow), although some clones can be shared among both hosts. This fact indicates that the successful transfer of bacteria between humans and animals (dairy cow) is limited ${ }^{35}$.

Other evidence of genetic heterogeneity and host specificity comes from an analysis of $S$. aureus strains isolated from bovine teat skin, human skin, milking equipment and bovine milk. The analysis employed the PFGE method of genomic DNA digested by SmaI. Twenty-four main types and 17 subtypes among the isolates of 43 herds were identified, and there was still discrimination between isolates of bovine teats and milk. Although small in number, identical pulsotypes were found on human skin and on bovine teat skin, whereas the milking equipment harbored distinct pulsotypes; that is, there were both skin and milk strains. These results suggest that S. aureus strains from skin and milk can be transmitted via milking machines; however, there is no relationship with potential sources of intramammary infections caused by S. aureus in dairy cows ${ }^{18}$. 


\section{Genetic relationship of S. aureus clusters/taxa}

The analysis of the genetic relationship among the $S$. aureus strains was determined satisfactorily using Nei's genetic distance ${ }^{53}$ and an UPGMA dendrogram ${ }^{55}$, as demonstrated by correlation coefficient based on Pearson product-moment $\left(r_{j k}=0.84949\right)$ [i.e., good agreement between $d_{i j}$ (matrix of genetic distance) and elements $C_{j k}$ (matrix of correlation derived from the UPGMA dendrogram)] (Supplemental Figure 1 and Supplemental Table 2). A high degree of genetic polymorphism $\left(0.000 \leq d_{i j}<0.381\right)$ was found in the total population of bacterial isolates (i.e., on average, from zero to 38.1 allele substitutions were detected for each 100 existing loci from a common ancestral strain). Such isolates were distributed within 80 taxa (from I to LXXX), which were determined from a genetic distance of $0.1175<d_{i j} \leq 0.3810$ (i.e., taxa genetically related to distance - strains/isolates not related). The taxon I presented a larger number of isolates, strains and bacterial clusters, followed by taxa IV, L, XXI, X, XXII, LXIV and LVII, LVI, V and II, XXIV, VI, XIII, III, XXIII and XXXVII, XXXVIII and LXVI, LXXIX, XVI, XLII and XVII, XII, XXXV and LXII, LIII, XLI and XXVI, LX, LII and LXVII, LIX, LXV, LXIX, XXIX, XLVI, LXIII and LXXIII, VIII, LI, IX, XI, XXX, XXXII and XXXIII, and others which had only one isolate/ET and no cluster. These results also suggest a high degree of genetic polymorphism because most isolates/strains of $S$. aureus $(n=365 ; 59.8 \%)$ can adapt to several population ecological niches (i.e., in two or even five distinct population origins: populations A, B, C, D and E), although allocated within few taxa ( $n=16$ : taxa I, IV, V, VI, VIII, X, XI, XIII, XXII, XXIII, XXX, XXXIII, L, LVI, LIX and LXIV). However, a lower frequency of highly polymorphic isolates/bacterial strains $(n=245 ; 40.2 \%)$ can be specific to certain population groups best adapted to their ecological niches, genetically divergent and distributed in many taxa $(n=64)$.

The genetic relationship among clusters and between clusters and isolated/strain non-clustered, although allocated within a single taxon, was considered moderately related $\left(0.0551<d_{i j} \leq 0.1175\right)$. In turn, each cluster has two or more isolates/strains that are identical or highly related $\left(0.000 \leq d_{i j} \leq 0.0551\right)$. Highly related strains come from a common ancestor, that is, descendants have undergone microevolution and adaptations as a consequence of recombination (not extensive), nucleotide mutations and non-random associations among genetic loci (linkage disequilibrium $)^{40,58}$. Therefore, these data suggest the possibility of intrapopulation microevolutionary processes for $S$. aureus (i.e., on average, from zero to 5.5 allele substitutions in 100 existing loci were detected from a common ancestral strain), as demonstrated in most of the clusters ( $n=75^{82.4 \%}$ clusters harboring isolates/ strains exclusively of populations A, B, C, D or E) and, consequently, the propagation of these microorganisms. However, epidemiological genotypic identity was suggested, that is, epidemiologically related populations maintain S. aureus strains (identical and/or highly related, moderately related, and completely unrelated) that genetically diverge from those epidemiologically unrelated populations. Interestingly, although occurring at a low frequency ( $n=16{ }^{17.6 \%}$ clusters), such microevolutionary changes or the co-existence of highly related strains (nonidentical) were observed among bacterial populations of different origins [i.e., co-existence of highly related strains in populations A and B (clusters II and XI), in populations $\mathrm{B}$ and $\mathrm{D}$ (clusters XXX, XLVI and XLVIII), in populations $\mathrm{B}$ and $\mathrm{E}$ (clusters XVII, XVIII, XX, XXVIII, LX, LXII and LXIX), in populations D and E (cluster XLIV), in populations $\mathrm{A}, \mathrm{B}$ and $\mathrm{D}$ (cluster XXIX), in populations $\mathrm{B}$, $\mathrm{D}$ and $\mathrm{E}$ (cluster XLV) and in populations A, B, D and $\mathrm{E}$ (cluster I)]. These results suggest the hypothesis that some bacterial strains of $S$. aureus can adapt and colonize new habitats by spreading from indirect sources and are not epidemiologically related. Consequently, the occurrence of a genotypic identity can take an epidemiological dynamic character (i.e., spread to new habitat), although this is a low-frequency occurrence. The geographical location of bacterial isolates of $S$. aureus can partially explain this epidemiological genotypic identity. In fact, the habitat can have an important role on the adaptation of genotypically related bacterial groups and the occurrence of that identity, given that the populations $\mathrm{A}$ and $\mathrm{B}$ or $\mathrm{C}, \mathrm{D}$ and $\mathrm{E}$ were geographically related.

The total genetic variability of populations of bacterial isolates, as proposed by $\mathrm{Nei}^{56}$, revealed a low index $(<5 \%)$ attributable to differences "between" populations and a high index attributable to differences "within" populations $(>95 \%)$. However, these data suggest a tendency of genetic divergence and microevolution between the $S$. aureus isolates of human origin (populations A and B) and bovine milkmaid origin (populations D and E), especially the mammary quarter animal anatomical site (population) (Figure 1). Another hypothesis suggests that populations from $S$. aureus strains of environmental and animal origin (populations D and E), as well as those of environmental and human origin (populations A and B), contribute little to the colonization (adaptation) and infection of certain animal anatomical sites (i.e., the mammary quarter, population C), regardless of the events of bacterial propagation, as previously described ${ }^{18,63,64}$. Under this hypothesis, intrinsic factors of the host could be involved in the selection and 
adaptation process or genetic convergence of groups of bacterial strains. This hypothesis should also be explored.

The molecular differentiation and clonal relationship (PFGE method and binary typing) of $S$. aureus (MRSA and MSSA) isolated from bovine mammary secretions, geographically unrelated bovines and humans (USA and the Netherlands), and the association of bacterial strains with the clinical observations in herds (clinical symptomatology and somatic cell counts - SCC) were analyzed ${ }^{65}$. Some PFGE (sub)types (A, F, G, B1, B2, E1 and E2) were identified only once, while PFGE types C, D and E were found in two, three, and four herds, respectively, as were 16 binary types. A limited number of prevalent types of $S$. aureus recovered from bovine mammary secretions, as well as the heterogeneity genetic, were found within and among herds ${ }^{65}$, suggesting that certain variants present in the environment may have a predilection for causing intramammary infections $s^{36,65-67}$. This genetic heterogeneity (subclonal) within the herds may be due to temporal evolution (longitudinal research over a year), allowing additional genetic diversification ${ }^{68,69}$. The cluster analysis (UPGMA method) associated with binary typing indicated clusters of bovine strains $(n=16)$ and human strains $(n=5)$ with 90 to $95 \%$ similarity. However, at the highest level of similarity (100\%), all the clones were host specific. These results were also consistent with the concept of host specificity among $S$. aureus clones and suggest that the successful transfer of bacteria between humans and animals is not a common event ${ }^{35,65}$, although possible ${ }^{13-14,18,42,61-63,70-73}$

$S$. aureus isolates $(n=227)$ from several herds of dairy cattle with mastitis, located in the southeastern region of Brazil (i.e., 18 dairy herds distributed among 9 municipal districts of the Rio de Janeiro State) were investigated using PFGE and MLST genotyping and analysis of genetic similarity (Dice coefficient and UPGMA algorithm) ${ }^{23}$. The PFGE method identified 60 pulsotypes (strains), which were distributed among 6 clonal complexes (CCs) (i.e., each clonal complex realized pulsotypes with $S_{\text {Dice }}>65 \%$ ) characterized by MLST. The predominance of a limited number of closely related pulsotypes (suggesting common ancestry) responsible for bovine mastitis in distinct herds (different geographical locations) and within the herds suggested that these strains have a greater capacity to propagate and cause intramammary infections. The majority of pulsotypes belonged to CC126 (recovered from 13 herds and 8 municipal districts) and CC97 (recovered from 14 herds and 9 municipal districts), which was represented by $91 \%$ of the isolates ${ }^{23}$. Observations indicated that CC 97 and $\mathrm{CC} 126$ were rarely or never detected among bacterial isolates from human population, respectively, suggesting the specificity of intramammary infections to ruminants ${ }^{23,40,42}$.
In addition, important $\mathrm{CCs}$ associated with infections by S. aureus in humans (CC1, CC5 and CC30) were found in bacterial isolates from dairy cattle in 6 herds located in 5 municipal districts ${ }^{23}$.

A prospective analysis using PFGE typing (bacterial genomic DNA digested with SmaI), PCR of virulence genes (hemolysins - hla to hlg; leukocidins - lukED and $l u k \mathrm{M}$; superantigens - sea, sec, sed, of seg to seo, seu and tst; adhesins - fnbA and $f n b \mathrm{~B}$; and resistance to penicillin and methicillin - blaZ and mecA) and genetic relationship (coefficient of Dice and grouping analyses) of $S$. aureus, collected from intramammary infection sites and other extramammary sources (teat skin of dairy cows, teat channels and skin lesions; milking liners; hands and nostrils of milking staff) from two dairy herds independent establishments (herds I and II) of southern Finland, was performed to study the possible sources and reservoirs of bovine intramammary infections ${ }^{20}$. In this research, unique predominant bacterial genotypes were found in each herd, with the number of pulsotypes in the herd II (an open herd, including imported heifers from different regions of Finland) higher $(n=7)$ than that from herd I (a closed herd; $n=3$ ), corroborating other reports on the high polymorphism (i.e., higher genetic heterogeneity) of isolates obtained from open herds ${ }^{17}$. Despite the existence of specific pulsotypes within each herd, the genotypes that were most likely better adapted to extramammary multiplication also caused intramammary infections, suggesting the existence of potential extramammary sources as the means of transfer. No correlation was found between specific genes for virulence and the source of the isolate. Still, identical pulsotypes in different herds were reported as being capable of harboring different virulence genes and resistance. In a herd, some pre-labor heifers harbored S. aureus strains in colostrum similar to those of lactating animals, and in both herds, the milking workers also displayed $S$. aureus strains identical to those of the animals, but the origin of colonization was considered uncertain ${ }^{20}$. Other factors may contribute to the selection and diversity of S. aureus strains in herds. The number and diversity of $S$. aureus strains will most likely rise if new strains are introduced via importing cattle, as previously shown ${ }^{17,20}$. Still, the successful control of infection of mastitis can increase the diversity of strains but decrease the spread of strains within the herd, whereas the failure to control can lead to the spread of only one or a few dominant strains throughout the herd. Pre-parturient heifers can also be an important reservoir of $S$. aureus, and strains originating from their skins were capable of causing intramammary infections in dairy cattle from the same herd ${ }^{17}$. However, herds may also harbor different strains of those lactating 
cattle ${ }^{18}$. Recent reports on epidemiological studies of $S$. aureus strains in humans and animals, including isolates from bovine mastitis, suggest host specificity although a high degree of variation within and among clonal strains of $S$. aureus originating from different host animals ${ }^{74-77}$.

\section{CONCLUSION}

This research investigated the intra- and interpopulational genetic diversity of $S$. aureus from certain environments and anatomical sites of bovines and humans, epidemiologically related and nonrelated [i.e., the hands of professional dentists (population A), dental clinic environment air (population B), bovine milk from cows with and without mastitis (population C), an insufflator for milking equipment (population D) and milking environment air (population E)]. Monoclonal and polyclonal patterns of bacterial strains were detected in each of the populations, but isolates belonging to the same $S$. aureus strain were not found between the populations, which initially suggested genetic heterogeneity and the intrapopulational propagation of S. aureus strains.

The genetic relationship analysis revealed the distribution of strains within 80 taxa, genetically related to the distance $\left(d_{i j} \geq 0.1175\right)$, suggesting a high degree of polymorphism in the total population of the $S$. aureus strains. Most of these unrelated strains were distributed in a few taxa that could adapt to several population ecological niches (i.e., in two or even five distinct population origins), whereas a lower frequency of unrelated strains was distributed in many taxa and can adapt to specific ecological niche populations. The propagation of highly related intrapopulational $S$. aureus strains and the existence of microevolutionary processes were suggested by the observations of the contents of the clusters $\left(d_{i j}=0.0551\right)$. Bacterial sampling from epidemiologically related populations showed identical strains and/or strains highly related and diversified in clusters, but distinct from those strains from epidemiologically unrelated populations, suggesting an epidemiological genotypic identity.

In addition, the coexistence of highly related strains was also observed between bacterial populations of different origins, although at low frequency. These data reinforce the hypothesis that some bacterial strains of $S$. aureus can adapt and colonize new habitats from indirect propagation sources and are unrelated epidemiologically. Consequently, the occurrence of a genotypic identity can assume an epidemiological dynamic character (i.e., spread to new habitat), though infrequently. Ultimately, a low index $(<5 \%)$ attributable to differences "between" bacterial populations and a high rate attributable to differences "within" them $(>95 \%)$ were found. The tendency of genetic differences and microevolution between populations of $S$. aureus of human origin (populations A and B) and dairy cattle (populations $\mathrm{D}$ and $\mathrm{E}$ ) and their environment, especially the mammary quarter (population C), was suggested. Intrinsic factors of the host could be involved in the selection and adaptation process, or genetic convergence, of bacterial strains groups, which should be explored further in the future. This research contributes to the knowledge of the distribution and dissemination of strains and the implementation of measures for the control and eradication of $S$. aureus in important medical and dental clinic environments, as well as in animal environments and dairy production (e.g., good biosafety practices and infection control, use of personal and collective protective equipment, implementation of containment barriers, installation of air purifiers, periodic monitoring and treatment of the carrier state of pathogens).

\section{AUTHORS' CONTRIBUTIONS}

MFG Boriollo, RC Bassi and JF Höfling wrote and revised the draft, and MFG Boriollo and RC Bassi aided microbiological and genetic assays. MFG Boriollo and JF Höfling performed statistical analysis. MFG Boriollo and JF Höfling have given final approval of the version to be published. All authors have read and approved the final manuscript.

\section{ACKNOWLEDGEMENTS}

This study was supported by the Fundacao de Amparo a Pesquisa do Estado de Minas Gerais (FAPEMIG process $\mathrm{N}^{\circ}$ APQ-3897-4.03/07) and the Conselho Nacional de Desenvolvimento Cientifico e Tecnologico (CNPq process No 157768/2011-2).

We thank Elsevier Language Services for help with English language editing.

\section{CONFLICT OF INTERESTS}

The authors declare no conflicts of interests.

\section{REFERENCES}

1. Murashita T, Sugiki H, Kamikubo Y, Yasuda K. Surgical results for active endocarditis with prosthetic valve replacement: impact of culture-negative endocarditis on early and late outcomes. J Cardiothorac Surg. 2004;26:1104-11.

2. Bakthavatchalam YD, Nabarro LE, Veeraraghavan B. Evolving rapid methicillin-resistant Staphylococcus aureus detection: cover all the bases. J Glob Infect Dis. 2017;9:18-22.

3. Dawson MP, Smith AJ. Superbugs and the dentist: an update. Dent Update. 2006;33:198-208. 
4. Rakic M, Grusovin MG, Canullo L. The microbiologic profile associated with peri-implantitis in humans: a systematic review. Int J Oral Maxillofac Implants. 2016;31:359-68.

5. Suzuki J, Komatsuzawa H, Kozai K, Nagasaka N. In vitro susceptibility of Staphylococcus aureus including MRSA to four disinfectants. ASDC J Dent Child. 1997;64:260-3.

6. Bernardo WL, Boriollo MF, Gonçalves RB, Höfling JF. Staphylococcus aureus ampicillin-resistant from the odontological clinic environment. Rev Inst Med Trop Sao Paulo. 2005;47:19-24.

7. Motta RH, Ramacciato JC, Groppo FC, Pacheco AB, de MattosFilho TR. Environment contamination before, during and after dental treatment. Am J Dent. 2005;18:340-4.

8. Hackney RW Jr, Crawford JJ, Tulis JJ. Using a biological indicator to detect potential source of cross-contamination in the dental operatory. J Am Dent Assoc. 1998;129:1567-77.

9. Kurita H, Kurashina K, Honda T. Nosocomial transmission of methicillin-resistant Staphylococcus aureus via the surfaces of the dental operatory. Br Dent J. 2006;201:297-300.

10. Deb R, Kumar A, Chakraborty S, Verma AK, Tiwari R, Dhama $\mathrm{K}$, et al. Trends in diagnosis and control of bovine mastitis: a review. Pak J Biol Sci. 2013;16:1653-61.

11. Sommerhäuser J, Kloppert B, Wolter W, Zschöck M, Sobiraj A, Failing K. The epidemiology of Staphylococcus aureus infections from subclinical mastitis in dairy cows during a control programme. Vet Microbiol. 2003;96:91-102.

12. Zecconi A, Calvinho LA, Fox LK. Staphylococcus aureus intramammary infections. Brussels: IDF; 2006.

13. Fox LK, Gershman M, Hancock DD, Hutton CT. Fomites and reservoirs of Staphylococcus aureus causing intramammary infections as determined by phage typing: The effect of milking time hygiene practices. Cornell Vet. 1991;81:183-93.

14. Matos JS, White DG, Harmon RJ, Langlois BE. Isolation of Staphylococcus aureus from sites other than the lactating mammary gland. J Dairy Sci. 1991;74:1544-9.

15. Roberson JR, Fox LK, Hancock DD, Gay JM, Besser TE. Ecology of Staphylococcusaureus isolated from various sites on dairy farms. J Dairy Sci. 1994;77:3354-64.

16. Larsen HD, Sloth KH, Elsberg C, Enevoldsen C, Pedersen LH, Eriksen NH, et al. The dynamics of Staphylococcus aureus intramammary infection in nine Danish dairy herds. Vet Microbiol. 2000;71:89-101.

17. Middleton JR, Fox LK, Gay JM, Tyler JW, Besser TE. Use of pulsed-field gel electrophoresis for detecting differences in Staphylococcus aureus strain populations between dairy herds with different cattle importation practices. Epidemiol Infect. 2002;129:387-95.

18. Zadoks RN, van Leeuwen WB, Kreft D, Fox LK, Barkema HW, Schukken YH, et al. Comparison of Staphylococcus aureus isolates from bovine and human skin, milking equipment, and bovine milk by phage typing, pulsed-field gel electrophoresis, and binary typing. J Clin Microbiol. 2002;40:3894-902.

19. Jørgensen HJ, Mørk T, Caugant DA, Kearns A, Rørvik LM. Genetic variation among Staphylococcus aureus strains from Norwegian bulk milk. Appl Environ Microbiol. 2005;71:8352-61.

20. Haveri M, Hovinen M, Roslöf A, Pyörälä S. Molecular types and genetic profiles of Staphylococcus aureus strains isolated from bovine intramammary infections and extramammary sites. J Clin Microbiol. 2008;46:3728-35.

21. Selander RK, Caugant DA, Ochman H, Musser JM, Gilmour MN, Whittam TS. Methods of multilocus enzyme electrophoresis for bacterial population genetics and systematics. Appl Environ Microbiol. 1986;51:873-84.

22. Boerlin P. Applications of multilocus enzyme electrophoresis in medical microbiology. J Microbiol Methods. 1997;28:221-31.

23. Rabello RF, Moreira BM, Lopes RM, Teixeira LM, Riley LW, Castro AC. Multilocus sequence typing of Staphylococcus aureus isolates recovered from cows with mastitis in Brazilian dairy herds. J Med Microbiol. 2007;56:1505-11.

24. Selander RK, Whittam TS. Protein polymorphism and the genetic structure of populations. In: Nei M, Koehn RK, editors. Evolution of genes and proteins. Sunderland: Sinauer Associates; 1983. p.89-114.

25. Oxford GS, Rollinson D. Protein polymorphism: adaptive and taxonomic significance. London: Academic Press; 1983.

26. Caugant DA, Bøvre K, Gaustad P, Bryn K, Holten E, Høiby EA, et al. Multilocus genotypes determined by enzyme electrophoresis of Neisseria meningitides isolated from patients with systemic disease and from healthy carriers. J Gen Microbiol. 1986;132:641-52.

27. Napimoga MH, Kamiya RU, Rosa RT, Rosa EA, Hofling JF, Mattos-Graner R, et al. Genotypic diversity and virulence traits of Streptococcus mutans in caries-free and caries-active individuals. J Med Microbiol. 2004;53:697-703.

28. Rosa RT, Napimoga MH, Höfling JF, Gonçalves RB, Rosa EA. Clonal characterization of Streptococcus mutans strains by multilocus enzyme electrophoresis. Braz J Microbiol. 2006;37:17-9.

29. Tahmourespour A, Nabinejad A, Shirian H, Rosa EA, Tahmourespour S. Typing of Streptococcus mutans strains isolated from caries free and susceptible subjects by multilocus enzyme electrophoresis. Braz J Microbiol. 2013;44:873-7.

30. Pujol C, Joly S, Lockhart SR, Noel S, Tibayrenc M, Soll DR. Parity among the randomly amplified polymorphic DNA method, multilocus enzyme electrophoresis, and southern blot hybridization with the moderately repetitive DNA probe Ca3 for fingerprinting Candida albicans. J Clin Microbiol. 1997;35:2348-58.

31. Boriollo MF, Rosa EA, Gonçalves RB, Höfling JF. Parity among interpretation methods of MLEE patterns and disparity among clustering methods in epidemiological typing of Candida albicans. J Microbiol Methods. 2006;64:346-65. 
32. Boriollo MF, Bassi RC, Nascimento CM, Feliciano LM, Francisco SB, Barros LM, et al. Distribution and hydrolytic enzyme characteristics of Candida albicans strains isolated from diabetic patients and their non-diabetic consorts. Oral Microbiol Immunol. 2009;24:437-50.

33. Boriollo MF, Dias RA, Fiorini JE, Oliveira NM, Spolidório DM, de Souza HM, et al. Disparity between multilocus enzyme electrophoresis, microsatellite markers and pulsed-field gel electrophoresis in epidemiological tracking of Candida albicans. J Microbiol Methods. 2010;82:265-81.

34. Joo YS, Fox LK, Davis WC, Bohach GA, Park YH. Staphylococcus aureus associated with mammary glands of cows: Genotyping to distinguish different strains among herds. Vet Microbiol 2001;80:131-8

35. Kapur V, Sischo WM, Greer RS, Whittman TS, Musser JM. Molecular population genetic analysis of Staphylococcus aureus recovered from cows. J Clin Microbiol. 1995;33:37680.

36. Fitzgerald JR, Meaney WJ, Hartigan PJ, Smyth CJ, Kapur V. Fine-structure molecular epidemiological analysis of Staphylococcus aureus recovered from cows. Epidemiol Infect. 1997;119:261-9.

37. Mørk TL, Tollersrud T, Kvitle B, Jørgensen HJ, Waage S. Comparison of Staphylococcus aureus genotypes recovered from cases of bovine, ovine, and caprine mastitis. J Clin Microbiol. 2005;43:3979-84.

38. Enright MC, Day NP, Davies CE, Peacock SJ, Spratt BG. Multilocus sequence typing for characterization of methicillinresistant and methicillin-susceptible clones of Staphylococcus aureus. J Clin Microbiol. 2000;38:1008-15.

39. Enright MC, Robinson DA, Randle G, Feil EJ, Grundmann H, Spratt BG. The evolutionary history of methicillin-resistant Staphylococcus aureus (MRSA). Proc Natl Acad Sci USA 2002;99:7687-92.

40. Feil EJ, Cooper JE, Grundmann H, Robinson DA, Enright MC, Berendt T, et al. How clonal is Staphylococcus aureus? J Bacteriol. 2003;185:3307-16.

41. Vivoni AM, Diep BA, Magalhães AC, Santos KR, Riley LW, Sensabaugh GF, et al. Clonal composition of Staphylococcus aureus isolates at a Brazilian university hospital: identification of international circulating lineages. J Clin Microbiol 2006;44:1686-91.

42. Smith EM, Green LE, Medley GF, Bird HE, Fox LK, Schukken $\mathrm{YH}$, et al. Multilocus sequence typing of intercontinental bovine Staphylococcus aureus isolates. J Clin Microbiol 2005;43:4737-43.

43. Smith EM, Green LE, Medley GF, Bird HE, Dowson CG. Multilocus sequence typing of Staphylococcus aureus isolated from high-somatic-cell-count cows and the environment of an organic dairy farm in the United Kingdom. J Clin Microbiol. 2005;43:4731-6.
44. Gomes AR, Westh H, de Lencastre H. Origins and evolution of methicillin-resistant Staphylococcus aureus clonal lineages. Antimicrob Agents Chemother. 2006;50:3237-44.

45. Winn WC Jr, Allen SD, Janda WM, Koneman EW, Procop GW, Schreckenberger PC, et al. Koneman's color atlas and textbook of diagnostic microbiology. $6^{\text {th }}$ ed. Philadelphia: Lippincott Williams \& Wilkins; 2008

46. Clinical and Laboratory Standards Institute. Performance standards for antimicrobial disk susceptibility tests: approved standard. $11^{\text {th }}$ ed. Wayne: CLSI; 2012.

47. Clinical and Laboratory Standards Institute. Performance standards for antimicrobial susceptibility testing: twentysecond informational supplement. Wayne: CLSI; 2012.

48. Clinical and Laboratory Standards Institute. Methods for dilution antimicrobial susceptibility tests for bacteria that grow aerobically: approved standard. $9^{\text {th }}$ ed. Wayne: CLSI; 2012.

49. Simpson EH. Measurement of diversity. Nature. 1949;163:688.

50. Armitage P, Berry G. Statistical methods in medical research. $2^{\text {nd }}$ ed. Oxford: Blackwell Scientific; 1987.

51. Hunter PR, Gaston MA. Numerical index of the discriminatory ability of typing systems and application of Simpson's index of diversity. J Clin Microbiol. 1988;26:2465-6.

52. Hunter PR, Fraser CA. Application of a numerical index of discriminatory power to a comparison of four physiochemical typing methods for Candida albicans. J Clin Microbiol. 1989;27:2156-60.

53. Nei M. Genetic distances between populations. Am Nat. 1972;106:283-92.

54. Boriollo MF, Rosa EA, Bernardo WL, Spolidorio DM, Gonçalves RB, Höfling JF. Multilocus enzyme electrophoresis typing of Candida albicans populations isolated from healthy children according to socioeconomic background. Rev Bras Epidemiol. 2005;8:51-66.

55. Sneath PH, Sokal RR. Numerical taxonomy: the principles and practice of numerical classification. San Francisco: W. H. Freeman; 1973.

56. Nei M. Analysis of gene diversity in subdivided populations. Proc Natl Acad Sci USA. 1973;70:3321-3.

57. Koreen L, Ramaswamy SV, Graviss EA, Naidich S, Musser JM, Kreiswirth BN. spa typing method for discriminating among Staphylococcus aureus isolates: implications for use of a single marker to detect genetic micro- and macrovariation. J Clin Microbiol. 2004;42:792-9.

58. Fitzgerald JR, Sturdevant DE, Mackie SM, Gill SR, Musser JM. Evolutionary genomics of Staphylococcus aureus: insights into the origin of methicillin-resistant strains and the toxic shock syndrome epidemic. Proc Natl Acad Sci USA. 2001;98:8821-6.

59. Musser JM, Kapur V. Clonal analysis of methicillin-resistant Staphylococcus aureus strains from intercontinental sources: association of the mec gene with divergent phylogenetic 
lineages implies dissemination by horizontal transfer and recombination. J Clin Microbiol. 1992;30:2058-63.

60. Musser JM, Schlievert PM, Chow AW, Ewan P, Kreiswirth BN, Rosdahl VT, et al. A single clone of Staphylococcus aureus causes the majority of cases of toxic shock syndrome. Proc Natl Acad Sci USA. 1990;87:225-9.

61. Lopes CA, Moreno G, Curi PR, Gottschalk AF, Modolo JR, Horacio A, et al. Characteristics of Staphylococcus aureus from subclinical bovine mastitis in Brazil. Br Vet J. 1990;146:443-8.

62. Musser JM, Selander RK. Genetic analysis of natural populations of Staphylococcus aureus. In: Novick R, editor. Molecular biology of the staphylococci. New York: VCH; 1990. p.59-67.

63. Schlegelová J, Dendis M, Benedík J, Babák, Rysánek D. Staphylococcusaureus isolates from dairy cows and humans on a farm differ in coagulase genotype. Vet Microbiol. 2003;92:327-34.

64. Aires-de-Sousa M, Parente CE, Vieira-da-Motta O, Bonna IC, Silva DA, de Lencastre H. Characterization of Staphylococcus aureus isolates from buffalo, bovine, ovine and caprine milk samples collected in Rio de Janeiro State, Brazil. Appl Environ Microbiol. 2007;73:3845-9.

65. Zadoks RN, van Leeuwen W, Barkema H, Sampimon O, Verbrugh H, Schukken YH, et al. Application of pulsed-field gel electrophoresis and binary typing as tools in veterinary clinical microbiology and molecular epidemiologic analysis of bovine and human Staphylococcus aureus isolates. J Clin Microbiol. 2000;38:1931-9.

66. Aarestrup FM, Dangler CA, Sordillo LM. Prevalence of coagulase gene polymorphism in Staphylococcusaureus isolates causing bovine mastitis. Can J Vet Res. 1995;59:124-8.

67. Su C, Herbelin C, Frieze N, Skardova O, Sordillo LM. Coagulase gene polymorphism of Staphylococcus aureus isolates from dairy cattle in different geographical areas. Epidemiol Infect. 1999;122:329-36.

68. van Leeuwen W, van Belkum A, Kreiswirth B, Verbrugh H. Genetic diversification of methicillin-resistant Staphylococcus aureus as a function of prolonged geographic dissemination and as measured by binary typing and other genotyping methods. Res Microbiol. 1998;149:497-507.

69. O’Brien FG, Pearman JW, Gracey M, Riley TV, Grubb WB. Community strain of methicillin-resistant Staphylococcus aureus involved in a hospital outbreak. J Clin Microbiol. 1999;37:2858-62.

70. Swartz R, Jooste PJ, Novello JC. Bacteriophage typing of Staphylococcus aureus strains isolated from Bloemfontein dairy herds. J S Afr Vet Assoc. 1985;56:69-73.

71. Seguin JC, Walker RD, Caron JP, Kloos WE, George CG, Hollis RJ, et al. Methicillin-resistant Staphylococcus aureus outbreak in a veterinary teaching hospital: potential human-to-animal transmission. J Clin Microbiol. 1999;37:1459-63.

72. Lee JH. Methicillin (oxacillin)-resistant Staphylococcus aureus strains isolated from major food animals and their potential transmission to humans. Appl Environ Microbiol. 2003;69:6489-94.

73. Gilot P, van Leeuwen W. Comparative analysis of agr locus diversification and overall genetic variability among bovine and human Staphylococcus aureus isolates. J Clin Microbiol. 2004;42:1265-9.

74. van Leeuwen WB, Melles DC, Alaidan A, Al-Ahdal M, Boelens HA, Snijders, et al. Host- and tissue-specific pathogenic traits of Staphylococcus aureus. J Bacteriol. 2005;187:4584-91.

75. Herron-Olson L, Fitzgerald JR, Musser JM, Kapur V. Molecular correlates of host specialization in Staphylococcus aureus. PLoS One. 2007;2:e1120.

76. Sung JM, Lloyd DH, Lindsay JA. Staphylococcus aureus host specificity: comparative genomics of human versus animal isolates by multi-strain microarray. Microbiology. 2008;154:1949-59.

77. Ben Zakour NL, Sturdevant DE, Even S, Guinane CM, Barbey C, Alves PD, et al. Genome-wide analysis of ruminant Staphylococcus aureus reveals diversification of the core genome. J Bacteriol. 2008;190:6302-17. 


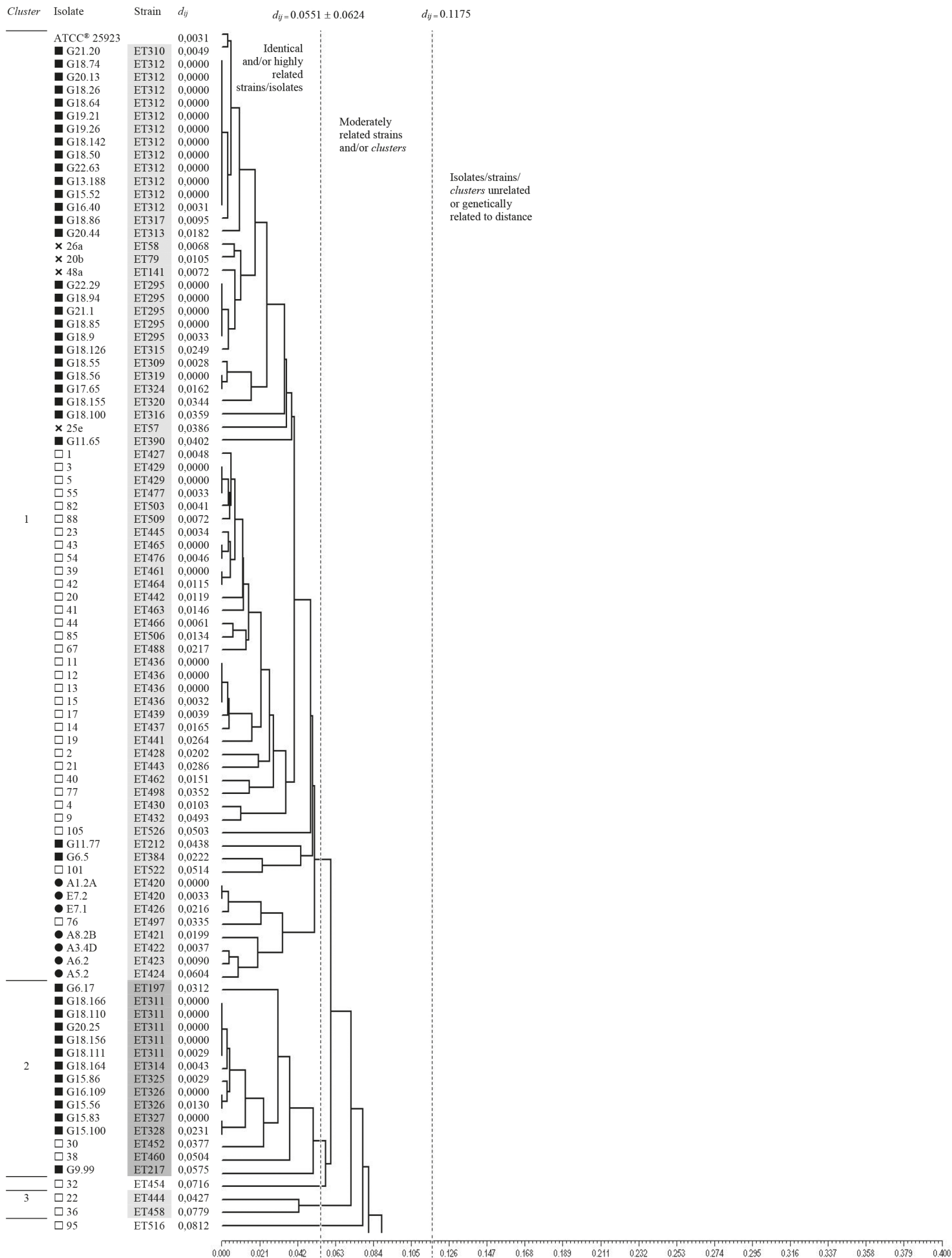

Supplemental Figure 1 - Genetic relationship between 554 strains of $S$. aureus, including the type strain S. aureus ATCC ${ }^{\circledR} 25923$, from five bacterial populations $\left(A^{\square}\right.$ : hands of professional dentists; $B^{\bullet}$ : dental clinic environment air; $C^{\circ}$ : bovine milk from cows with and without mastitis; $D^{\bullet}$ : insufflator for milking equipment; and $\mathrm{E}^{\mathbf{x}}$ : milking environment air). UPGMA dendrogram $\left(r_{i k}=0.84949\right.$ : good concordance) generated from the genetic distance matrix ${ }^{53}$ and the genetic interpretation of the patterns MLEE 


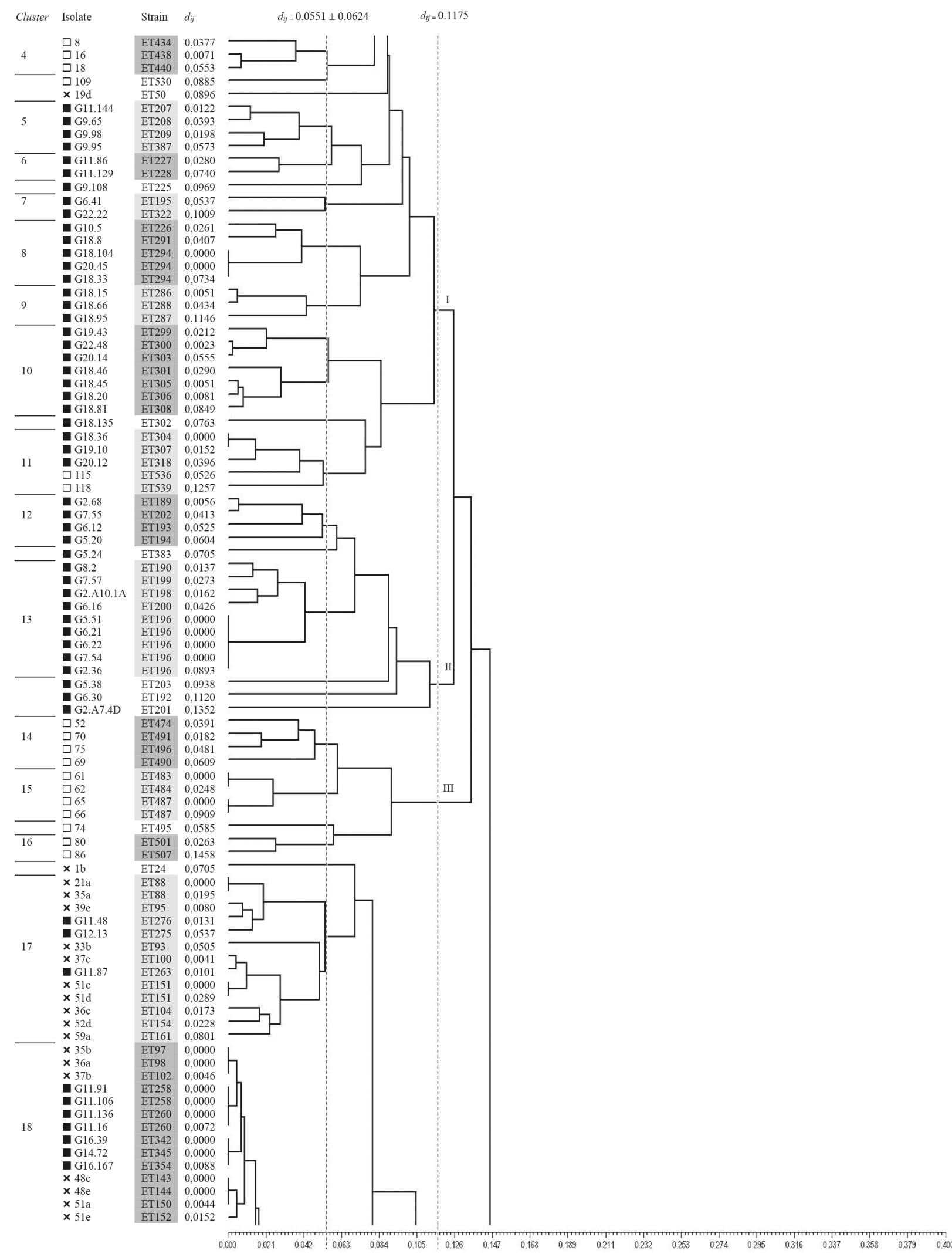

Supplemental Figure 1 - Genetic relationship between 554 strains of $S$. aureus, including the type strain $S$. aureus ATCC ${ }^{\circledR} 25923$, from five bacterial populations $\left(A^{\square}\right.$ : hands of professional dentists; $B^{\square}$ : dental clinic environment air; $C^{\circ}$ : bovine milk from cows with and without mastitis; $D^{\bullet}$ : insufflator for milking equipment; and $E^{*}$ : milking environment air). UPGMA dendrogram $\left(r_{j k}=0.84949\right.$ : good concordance) generated from the genetic distance matrix ${ }^{53}$ and the genetic interpretation of the patterns MLEE (cont.) 


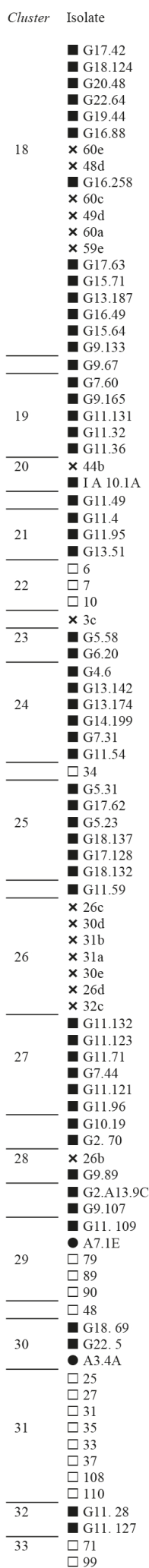

Strain $d_{i j}$

ET375 0,0000
ET375

$\begin{array}{lll}\text { ET375 } & 0,0000 \\ \text { ET379 } & 0,0097\end{array}$

\begin{tabular}{ll|l} 
ET379 & 0,0097 \\
ET380 & 0,0168
\end{tabular}

$\begin{array}{ll}\text { ET378 } & 0,0185\end{array}$

ET338 0,0189

$\begin{array}{ll}\text { ET167 } & 0,0262\end{array}$

\begin{tabular}{l|l} 
ET145 & 0,0287 \\
ET355 & 0,0358
\end{tabular}

$\begin{array}{ll}\text { ET355 } & 0,0358\end{array}$

$\begin{array}{ll}\text { ET166 } & 0,0398 \\ \text { ET148 } & 0,0041\end{array}$

\begin{tabular}{ll|l} 
ET148 & 0,0041 \\
ET165 & 0,0063 \\
\hline
\end{tabular}

$\begin{array}{lll}\text { ET165 } & 0,0063\end{array}$

ET164 0,0157

ET372 0,0206

ET335 0,0040

ET336 0,0061

$\begin{array}{lll}\text { ET341 } & 0,0344\end{array}$

$\begin{array}{ll}\text { ET371 } & 0,0468\end{array}$

$\begin{array}{ll}\text { ET389 } & 0,0639 \\ \text { ET388 } & 0,0725\end{array}$

ET365 0,0126

ET366 0,0427

ET367 0,0000

ET367 0,0174

ET367 0,104

$\begin{array}{ll}\text { ET126 } & 0,0277\end{array}$

ET381 0,0616

ET283 0,0908

ET261 0,0340

ET265 0,0066

ET281 0,1121

ET431 0,0181

$\begin{array}{lll}\text { ET433 } & 0,0457\end{array}$

$\begin{array}{ll}\text { ET435 } & 0,1177\end{array}$

ET34 0,0853

ET187 0,0370

ET205 0,0617

ET362 0,0166

$\begin{array}{lll}\text { ET369 } & 0,0070\end{array}$

\begin{tabular}{ll} 
ET370 & 0,0000 \\
\hline ET370 & 0,0501
\end{tabular}

\begin{tabular}{ll|l} 
ET370 & 0,0501 \\
ET364 & 0,0167
\end{tabular}

$\begin{array}{lll}\text { ET364 } & 0,0167 \\ \text { ET368 } & 0,0640\end{array}$

$\begin{array}{ll}\text { ET456 } & 0,0899\end{array}$

ET363 0,0045

ET374 0,0110

ET382 0,0406

ET377 0,0524

ET373 0,0178

$\begin{array}{lll}\text { ET376 } & 0,064\end{array}$

ET392 0,1304

ET60 0,0000

ET71 0,0000

ET74 0,0030

ET73 0,0446

ET72 0,0547

ET61 0,0323

$\begin{array}{ll}\text { ET78 } & 0,0776 \\ \text { ET215 } & 0,0157\end{array}$

$\begin{array}{ll}\text { ET216 } & 0,0381\end{array}$

$\begin{array}{ll}\text { ET216 } & 0,038 \\ \text { ET218 } & 0,0503\end{array}$

ET221 0,0096

ET269 0,0202

ET222 0,1119

ET214 0,1261

ET171 0,1385

$\begin{array}{lll}\text { ET59 } & 0,0539\end{array}$

ET230 0,1606

ET206 0,0850

ET229 0,1643

ET181 0,030

ET414 0,051

$\begin{array}{ll}\text { ET500 } & 0,0289 \\ \text { ET510 } & 0,0339\end{array}$

$\begin{array}{ll}\text { ET511 } & 0,0643\end{array}$

\begin{tabular}{ll} 
ET511 & 0,0643 \\
\hline ET470 & 0,0740
\end{tabular}

\begin{tabular}{lll} 
ET470 & 0,0740 \\
\hline ET185 & 0,0157
\end{tabular}

\begin{tabular}{l|l} 
ET185 & 0,0157 \\
ET186 & 0,0379
\end{tabular}

\begin{tabular}{l|l} 
ET186 & 0,0379 \\
ET419 & 0,0577
\end{tabular}

$\begin{array}{ll}\text { ET419 } & 0,0577\end{array}$

ET447 0,0140

ET449 0,0352

ET453 0,0180

ET457 0,023

ET455 0,0088

ET459 0,0550

ET529 0,0315

ET531 0,0907

ET183 0,0364

ET184 0,0956

ET520 0,0689

$d_{i j}=0.0551 \pm 0.0624 \quad d_{i j}=0.1175$

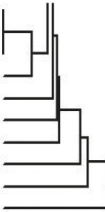

子
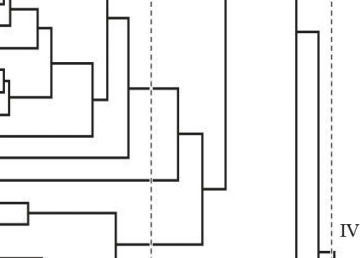

IV
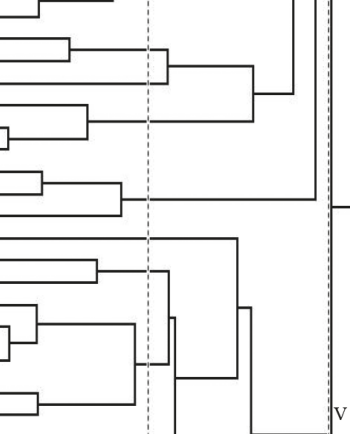

コ
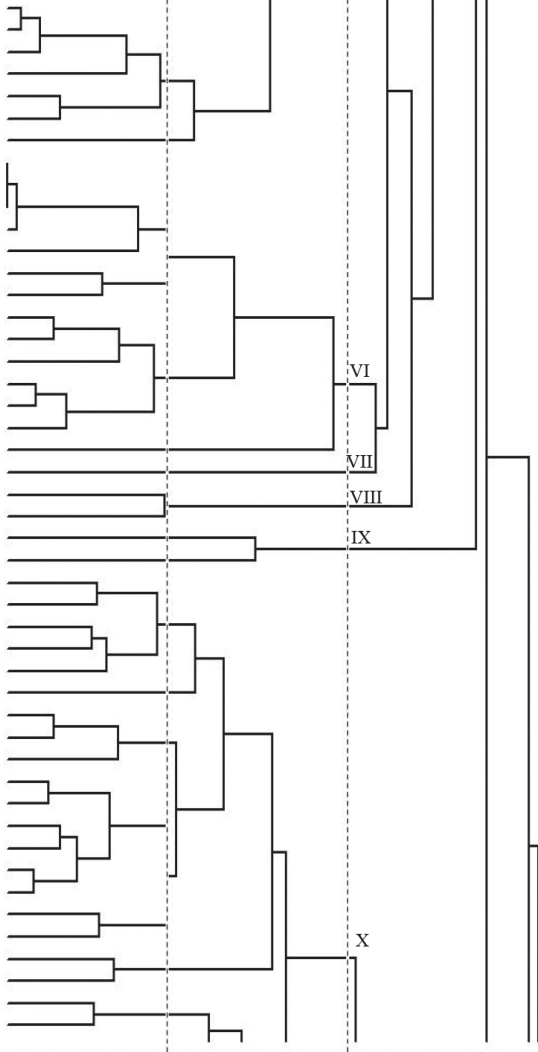

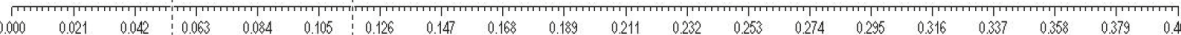

Supplemental Figure 1 - Genetic relationship between 554 strains of $S$. aureus, including the type strain S. aureus ATCC ${ }^{\circledR} 25923$, from five bacterial populations ( $A^{\square}$ : hands of professional dentists; $B^{\bullet}$ : dental clinic environment air; $C^{\circ}$ : bovine milk from cows with and without mastitis; $\mathrm{D}^{\bullet}$ : insufflator for milking equipment; and $\mathrm{E}^{\mathbf{x}}$ : milking environment air). UPGMA dendrogram ( $r_{j k}=0.84949$ : good concordance) generated from the genetic distance matrix ${ }^{53}$ and the genetic interpretation of the patterns MLEE (cont.) 


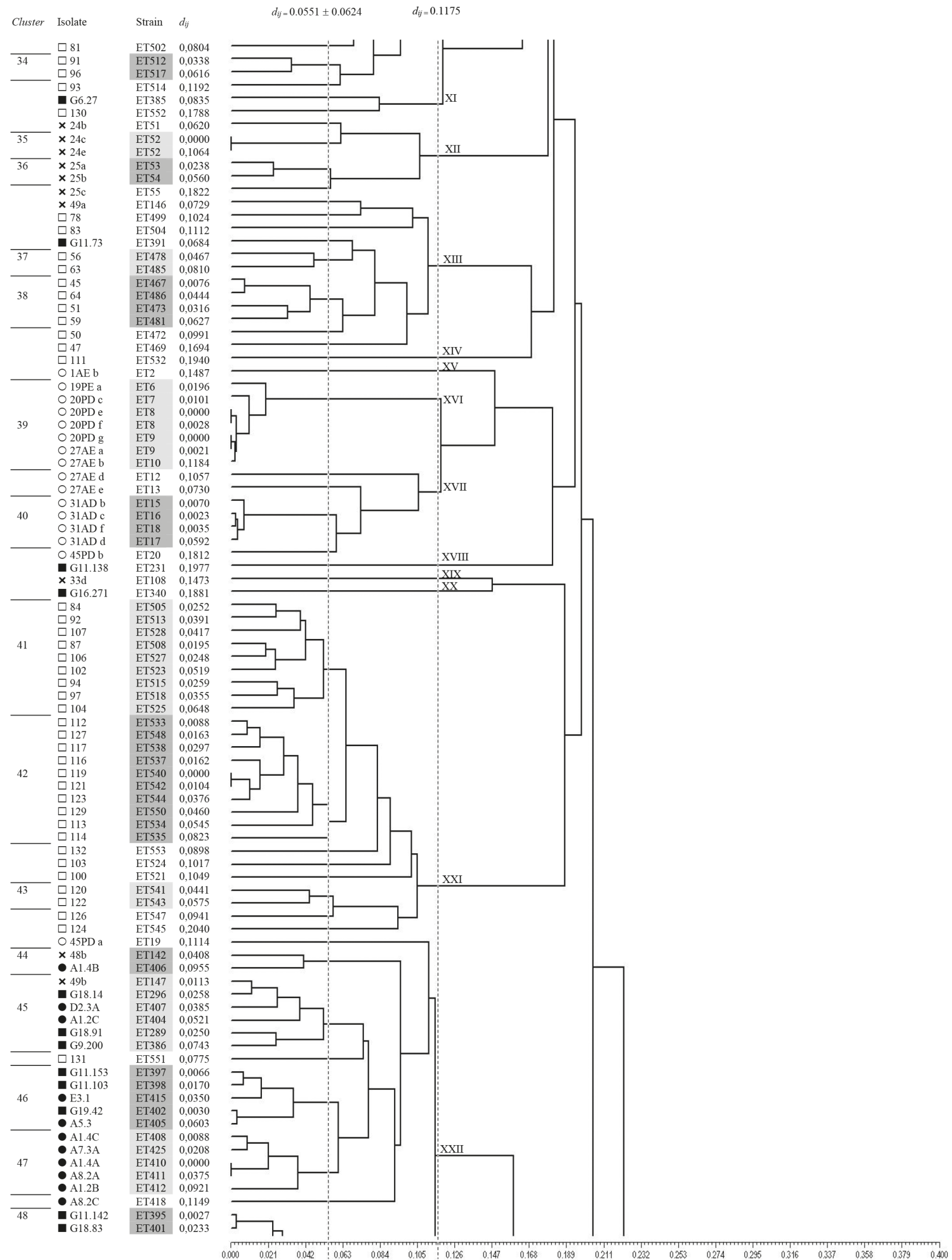

Supplemental Figure 1 - Genetic relationship between 554 strains of $S$. aureus, including the type strain $S$. aureus ATCC ${ }^{\circledR} 25923$, from five bacterial populations $\left(A^{\square}\right.$ : hands of professional dentists; $B^{\square}$ : dental clinic environment air; $C^{\circ}$ : bovine milk from cows with and without mastitis; $D^{\bullet}$ : insufflator for milking equipment; and $E^{*}$ : milking environment air). UPGMA dendrogram $\left(r_{j k}=0.84949\right.$ : good concordance) generated from the genetic distance matrix ${ }^{53}$ and the genetic interpretation of the patterns MLEE (cont.) 

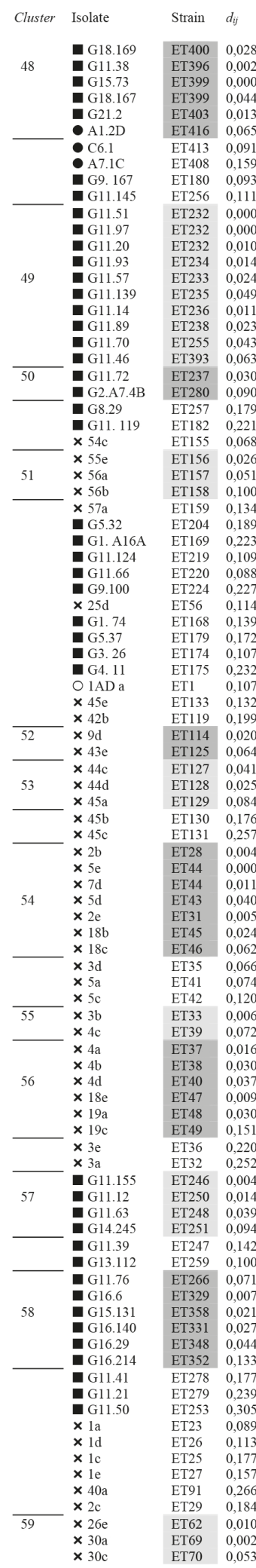

$d_{i j}=0.0551 \pm 0.0624$

$d_{i j}=0.1175$

ET400 0,0288

ET396 0,0029

\begin{tabular}{ll} 
ET399 & 0,0000 \\
\hline ET399 & 0,0440
\end{tabular}

\begin{tabular}{ll} 
ET403 & 0,0131 \\
\hline
\end{tabular}

\begin{tabular}{ll} 
ET416 & 0,0653 \\
\hline
\end{tabular}

ET413 0,0911

$\begin{array}{ll}\text { ET408 } & 0,1594 \\ \text { ET180 } & 0,0935\end{array}$

ET256 0,1115

ET232 0,0000

ET232 0,0000

ET232 0,0102

ET234 0,0149

$\begin{array}{ll}\text { ET235 } & 0,0494 \\ \text { ET }\end{array}$

ET236 0,0116

ET238 0,0233

ET255 0,0434

\begin{tabular}{lll} 
ET237 & 0,06301 \\
\hline ET23 & 0,0301
\end{tabular}

ET280 0,0903

\begin{tabular}{ll} 
ET280 & 0,0903 \\
\hline ET257 & 0,1799
\end{tabular}

ET182 0,2216

ETI56 0,0682

\begin{tabular}{ll} 
ET156 & 0,0261 \\
\hline
\end{tabular}

$\begin{array}{ll}\text { ET158 } & 0,1007\end{array}$

$\begin{array}{ll}\text { ET159 } & 0,1344 \\ \text { ET }\end{array}$

ET204 0,1893

$\begin{array}{ll}\text { ET169 } & 0,2239 \\ \text { ET219 } & 0,1092\end{array}$

$\begin{array}{ll}\text { ET219 } & 0,1092 \\ \text { ET220 } & 0,0889\end{array}$

$\begin{array}{ll}\text { ET220 } & 0,0889 \\ \text { ET224 } & 0,2270\end{array}$

ET56 0,1146

$\begin{array}{ll}\text { ET179 } & 0,1721\end{array}$

$\begin{array}{ll}\text { ET174 } & 0,1079\end{array}$

$\begin{array}{ll}\text { ET175 } & 0,1079 \\ \text { ET175 } & 0,2322\end{array}$

$\begin{array}{ll}\text { ET1 } & 0,1072\end{array}$

$\begin{array}{ll}\text { ET133 } & 0,1325 \\ \text { ET119 } & 0,1994\end{array}$

\begin{tabular}{l|l} 
ET114 & 0,0203
\end{tabular}

ET125 0,0645

$\begin{array}{ll}\text { ET127 } & 0,0419\end{array}$

$\begin{array}{ll}\text { ET128 } & 0,0255 \\ \text { ET129 } & 0,0844\end{array}$

$\begin{array}{ll}\text { ET129 } & 0,0844 \\ \text { ET130 } & 0,1765\end{array}$

ET131 0,2571

\begin{tabular}{l|l} 
ET28 & 0,0047 \\
ET44 & 0,0000
\end{tabular}

\begin{tabular}{l|l} 
ET44 & 0,0000 \\
ET44 & 0,0114
\end{tabular}

$\begin{array}{ll}\text { ET44 } & 0,0114 \\ \text { ET43 } & 0,0407\end{array}$

$\begin{array}{ll}\text { ET31 } & 0,0051\end{array}$

ET45 0,0240

$\begin{array}{lr}\text { ET46 } & 0,0629 \\ \text { ET35 } & 0,0662\end{array}$

$\begin{array}{ll}\text { ET35 } & 0,0662 \\ \text { ET41 } & 0,0741\end{array}$

$\begin{array}{ll}\text { ET41 } & 0,0741 \\ \text { ET42 } & 0,1200\end{array}$

$\begin{array}{ll}\text { ET33 } & 0,0067 \\ \text { ET39 } & 0,0729\end{array}$

\begin{tabular}{ll} 
ET39 & 0,0729 \\
\hline
\end{tabular}

$\begin{array}{ll}\text { ET37 } & 0,0168\end{array}$

ET38 0,0308

$\begin{array}{ll}\text { ET40 } & 0,0370\end{array}$

ET47 0,0093

$\begin{array}{ll}\text { ET48 } & 0,0303 \\ \text { ET49 } & 0,1518\end{array}$

ET49 0,1518

\begin{tabular}{ll} 
ET32 & 0,2529 \\
\hline
\end{tabular}

$\begin{array}{ll}\text { ET246 } & 0,0047\end{array}$

ET250 0,0141

ET248 0,0392

$\begin{array}{ll}\text { ET251 } & 0,0949\end{array}$

ET247 0,1427

$\begin{array}{ll}\text { E1259 } & 0,1009\end{array}$

$\begin{array}{ll}\text { ET266 } & 0,0712 \\ \text { ET329 } & 0,0075\end{array}$

$\begin{array}{ll}\text { ET329 } & 0,0075 \\ \text { ET358 } & 0,0215\end{array}$

ET331 0,0279

$\begin{array}{lll}\text { ET331 } & 0,0279 \\ \text { ET348 } & 0,0449\end{array}$

$\begin{array}{ll}\mathrm{ET} 352 & 0,1338\end{array}$

ET278 0,1777

$\begin{array}{ll}\text { ET279 } & 0,2397 \\ \text { ET253 } & 0,3053\end{array}$

$\begin{array}{ll}\text { ET23 } & 0,0898\end{array}$

$\begin{array}{ll}\text { ET26 } & 0,1135\end{array}$

$\begin{array}{ll}\text { ET25 } & 0,1777 \\ \text { ET27 } & 0,157\end{array}$

$\begin{array}{ll}\text { ET27 } & 0,1571 \\ \text { ET91 } & 0,2667\end{array}$

ET29 0,1848

\begin{tabular}{l|l} 
ET62 & 0,0108 \\
ET69 & 0,002
\end{tabular}

$\begin{array}{ll}\text { ET69 } & 0,0024 \\ \text { ET70 } & 0,0538\end{array}$
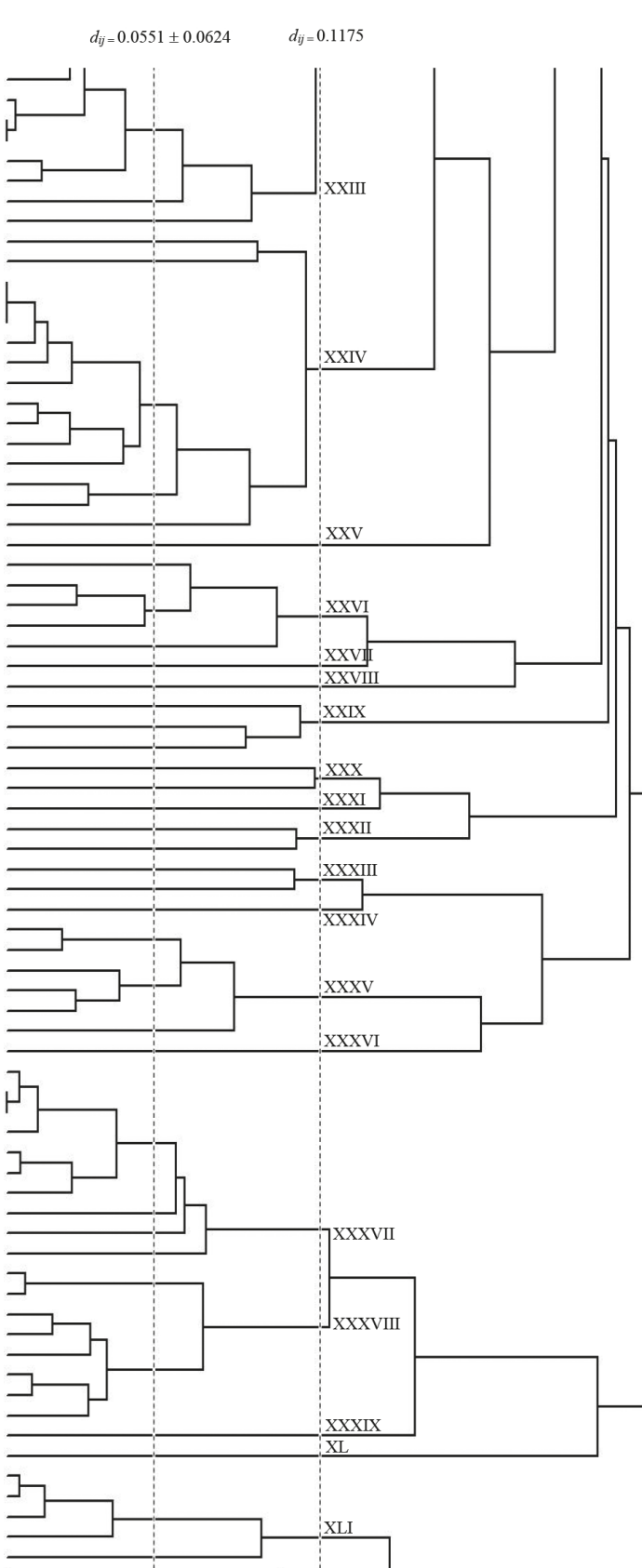

$$
\text { 刍 }
$$

$$
0.000 \quad 0.021 \quad 0.00
$$

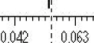
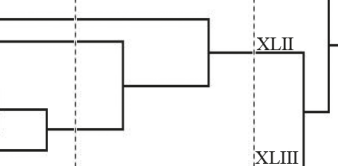

XLIV

XLIV

Supplemental Figure 1 - Genetic relationship between 554 strains of $S$. aureus, including the type strain S. aureus ATCC ${ }^{\circledR} 25923$, from five bacterial populations $\left(A^{\square}\right.$ : hands of professional dentists; $B^{\bullet}$ : dental clinic environment air; $C^{\circ}$ : bovine milk from cows with and without mastitis; $\mathrm{D}^{\bullet}$ : insufflator for milking equipment; and $\mathrm{E}^{\mathbf{*}}$ : milking environment air). UPGMA dendrogram ( $r_{i k}=0.84949$ : good concordance) generated from the genetic distance matrix ${ }^{53}$ and the genetic interpretation of the patterns MLEE (cont.) 


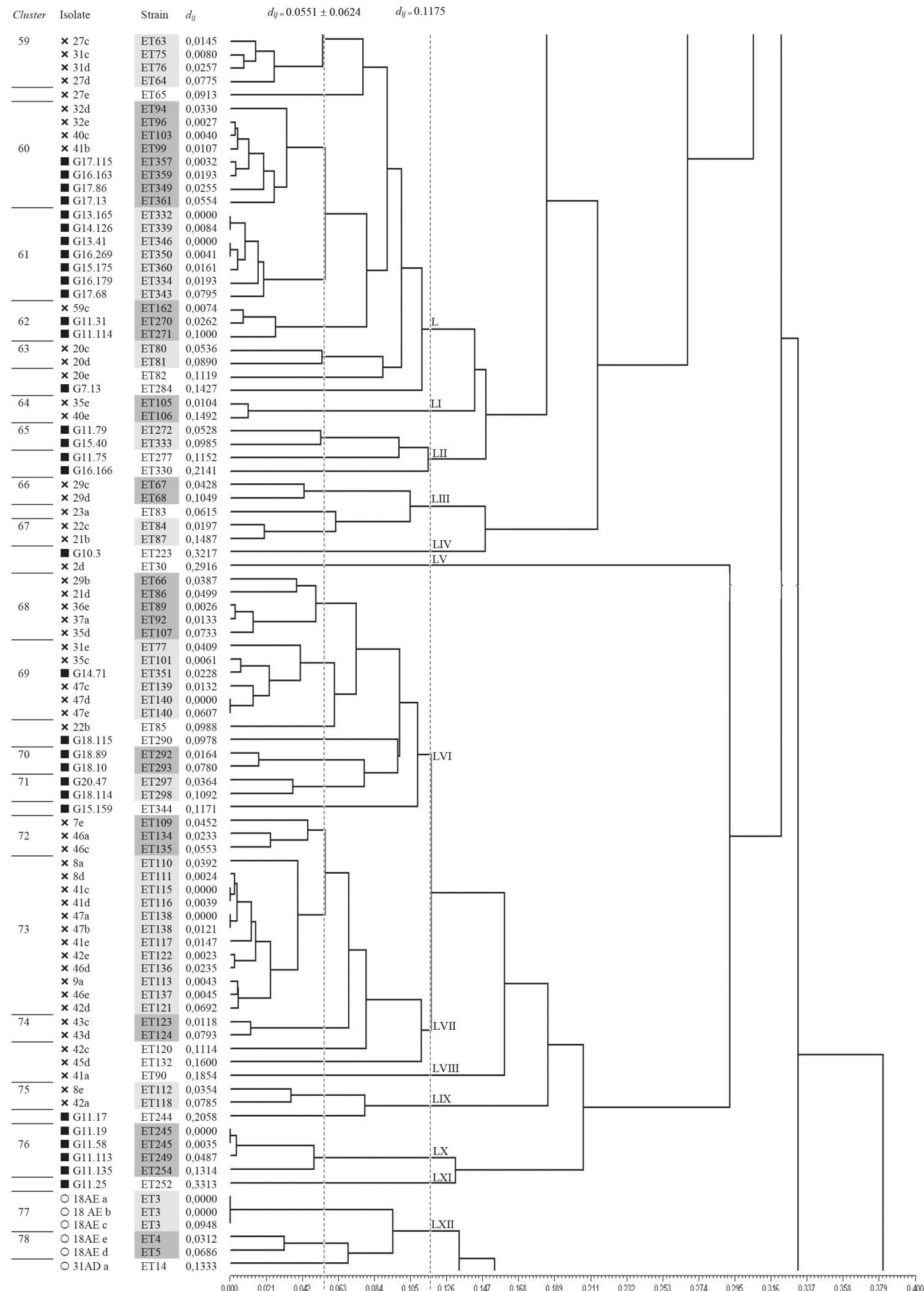

Supplemental Figure 1 - Genetic relationship between 554 strains of $S$. aureus, including the type strain $S$. aureus ATCC ${ }^{\circledR} 25923$, from five bacterial populations $\left(A^{\square}\right.$ : hands of professional dentists; $B^{\bullet}$ : dental clinic environment air; $C^{\circ}$ : bovine milk from cows with and without mastitis; $D^{\bullet}$ : insufflator for milking equipment; and $E^{*}$ : milking environment air). UPGMA dendrogram $\left(r_{j k}=0.84949\right.$ : good concordance) generated from the genetic distance matrix ${ }^{53}$ and the genetic interpretation of the patterns MLEE (cont.) 

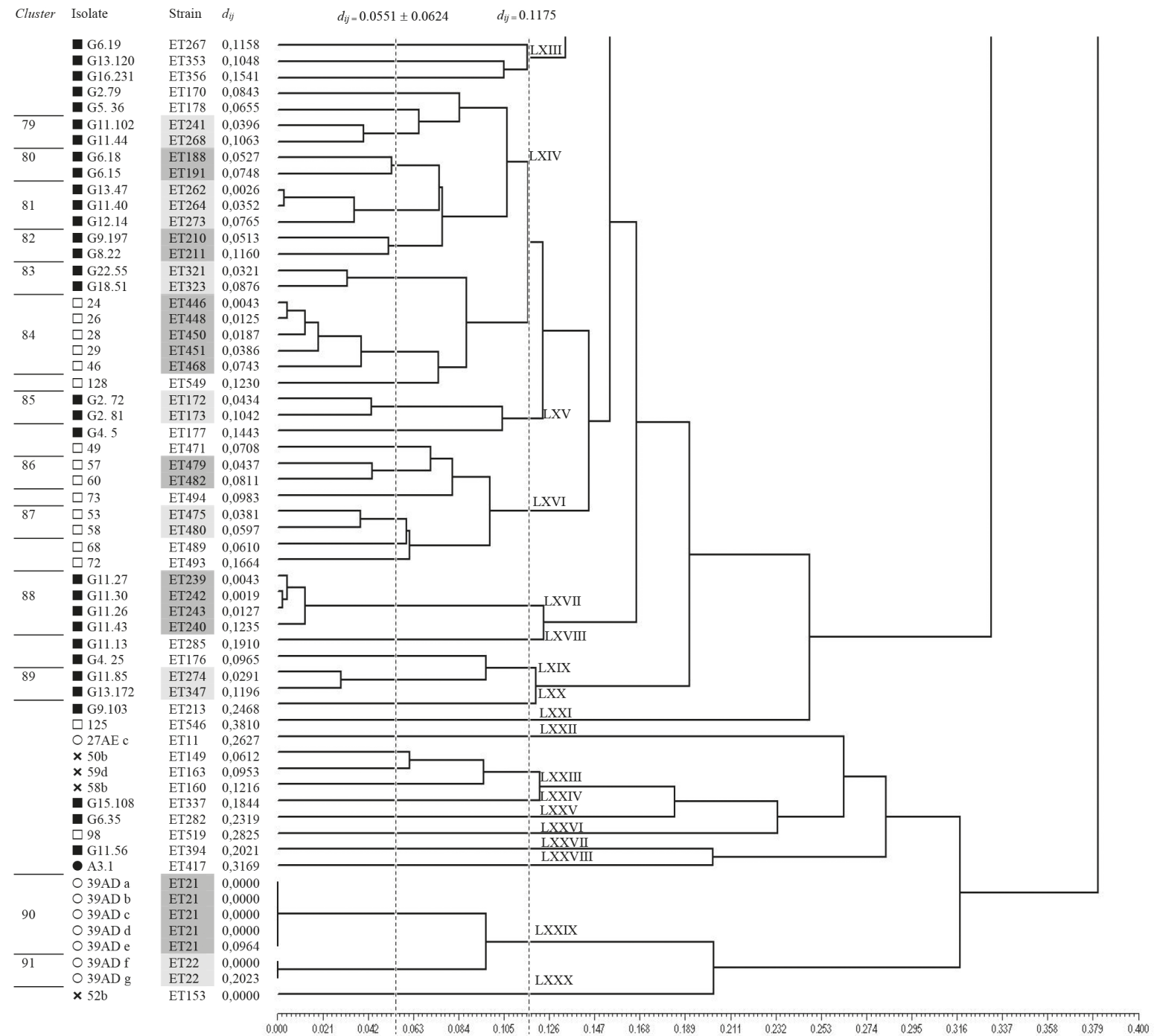

Supplemental Figure 1 - Genetic relationship between 554 strains of $S$. aureus, including the type strain S. aureus ATCC ${ }^{\circledR} 25923$, from five bacterial populations ( $\mathrm{A}^{\square}$ : hands of professional dentists; $\mathrm{B}^{\bullet}$ : dental clinic environment air; $\mathrm{C}^{\circ}$ : bovine milk from cows with and without mastitis; $\mathrm{D}^{\bullet}$ : insufflator for milking equipment; and $\mathrm{E}^{\mathbf{x}}$ : milking environment air). UPGMA dendrogram $\left(r_{j k}=0.84949\right.$ : good concordance) generated from the genetic distance matrix ${ }^{53}$ and the genetic interpretation of the patterns MLEE (cont.) 


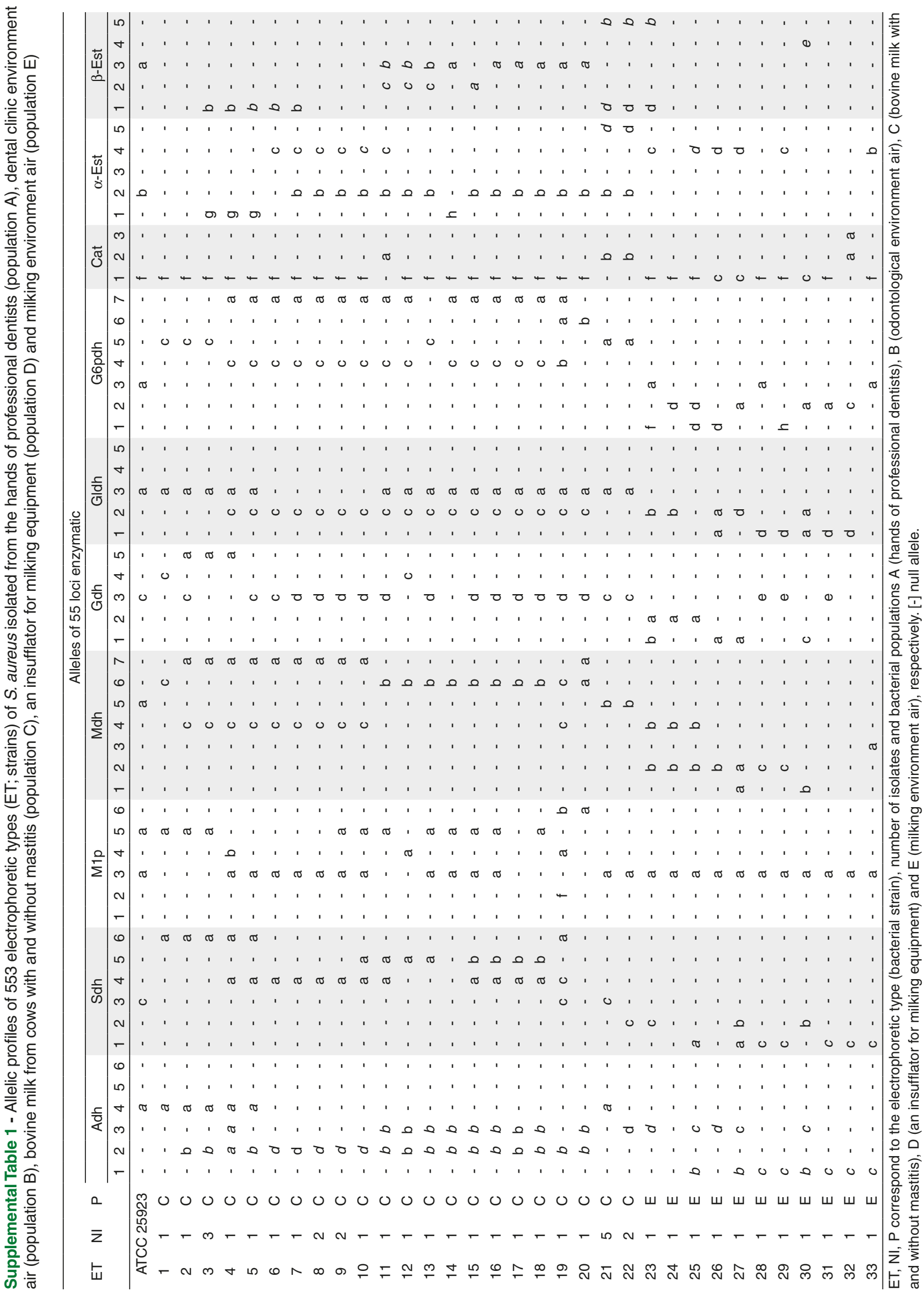




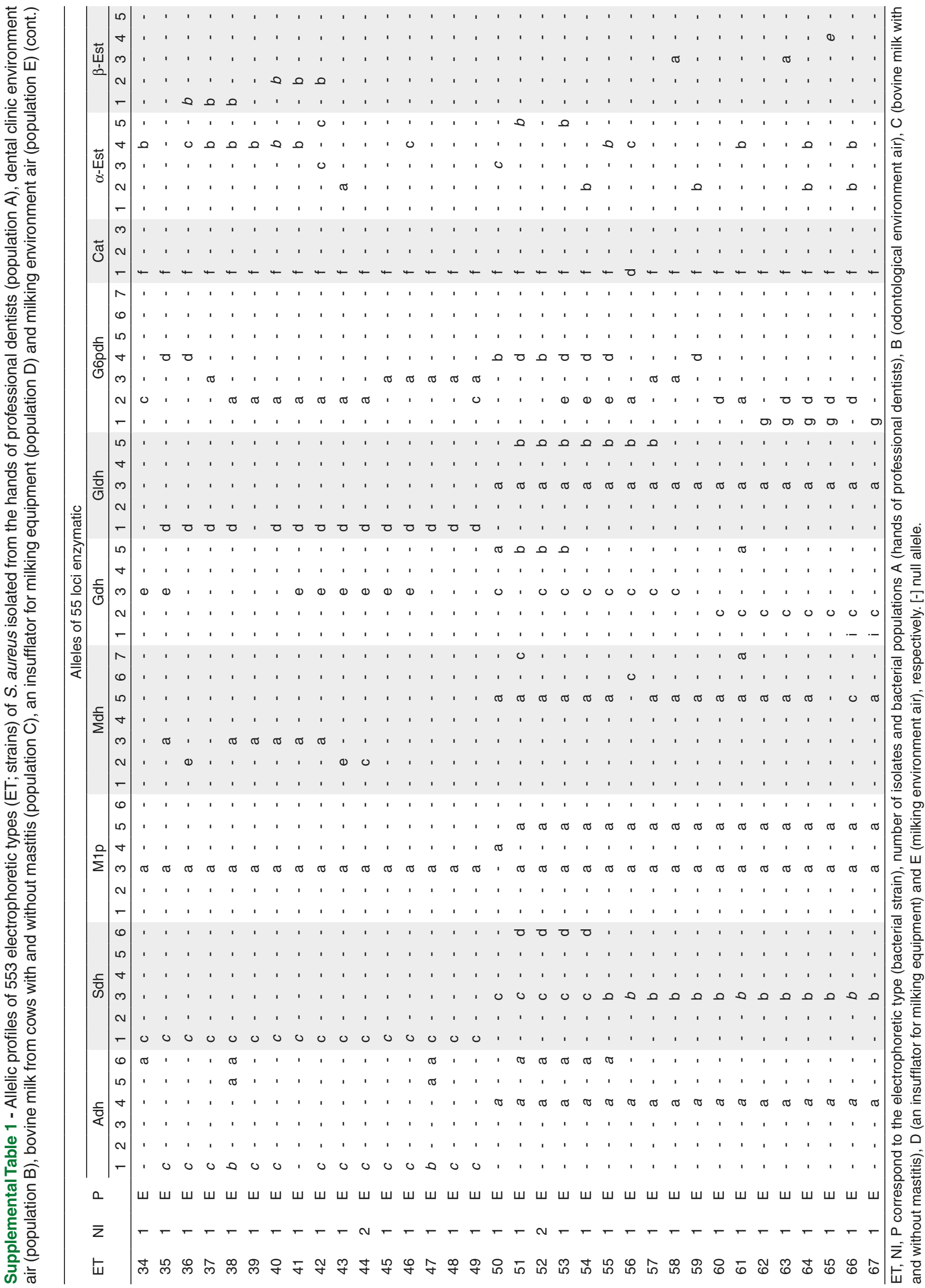




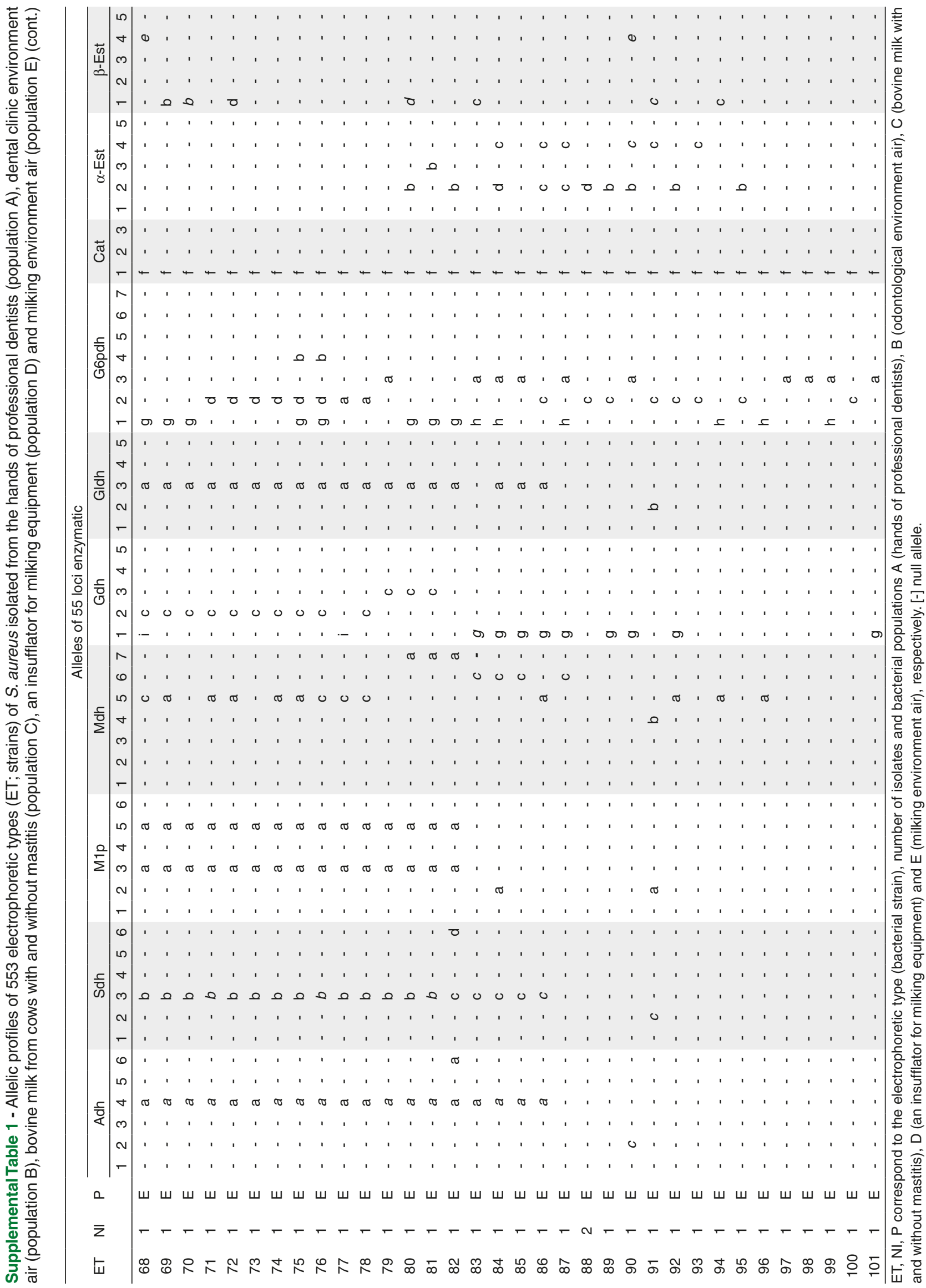




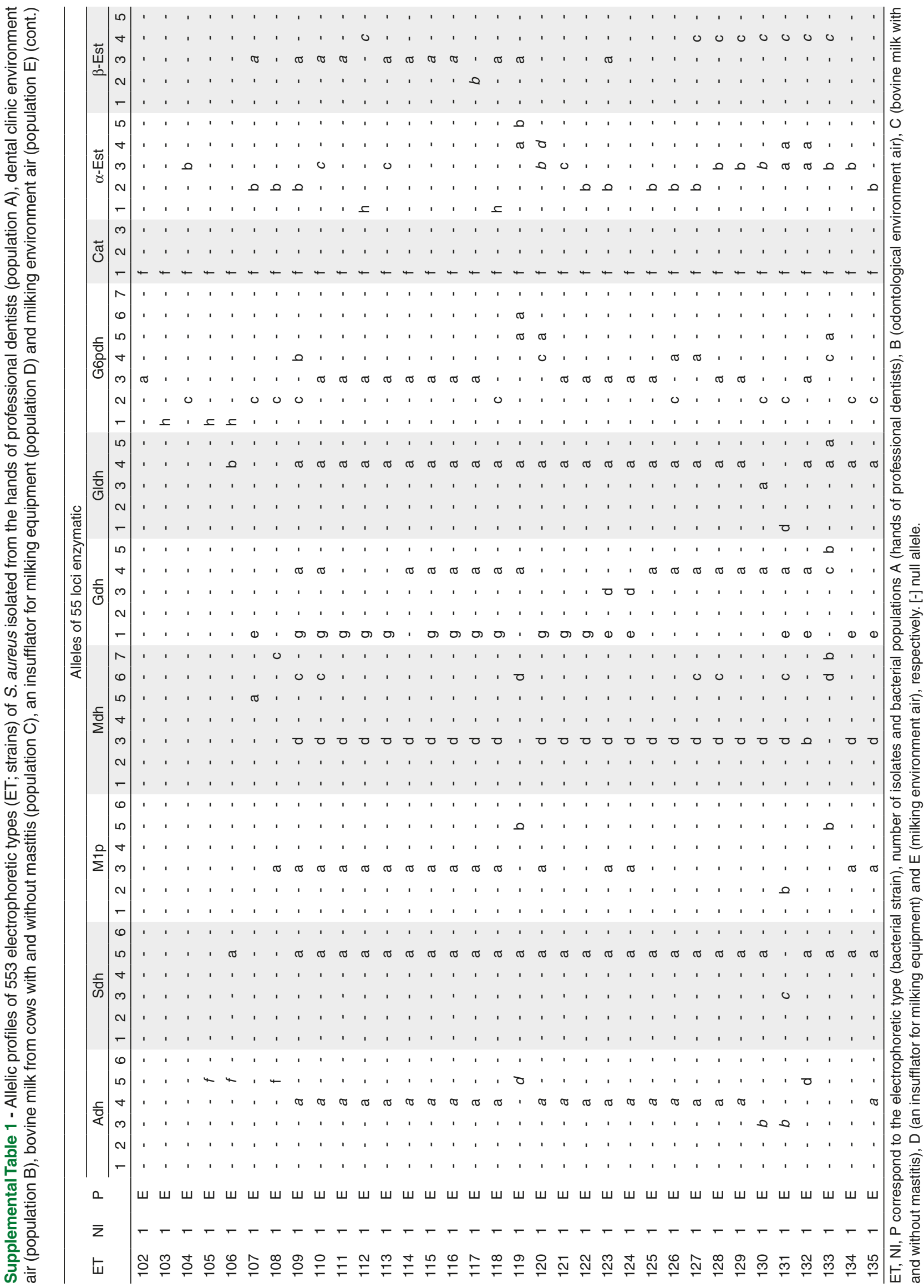




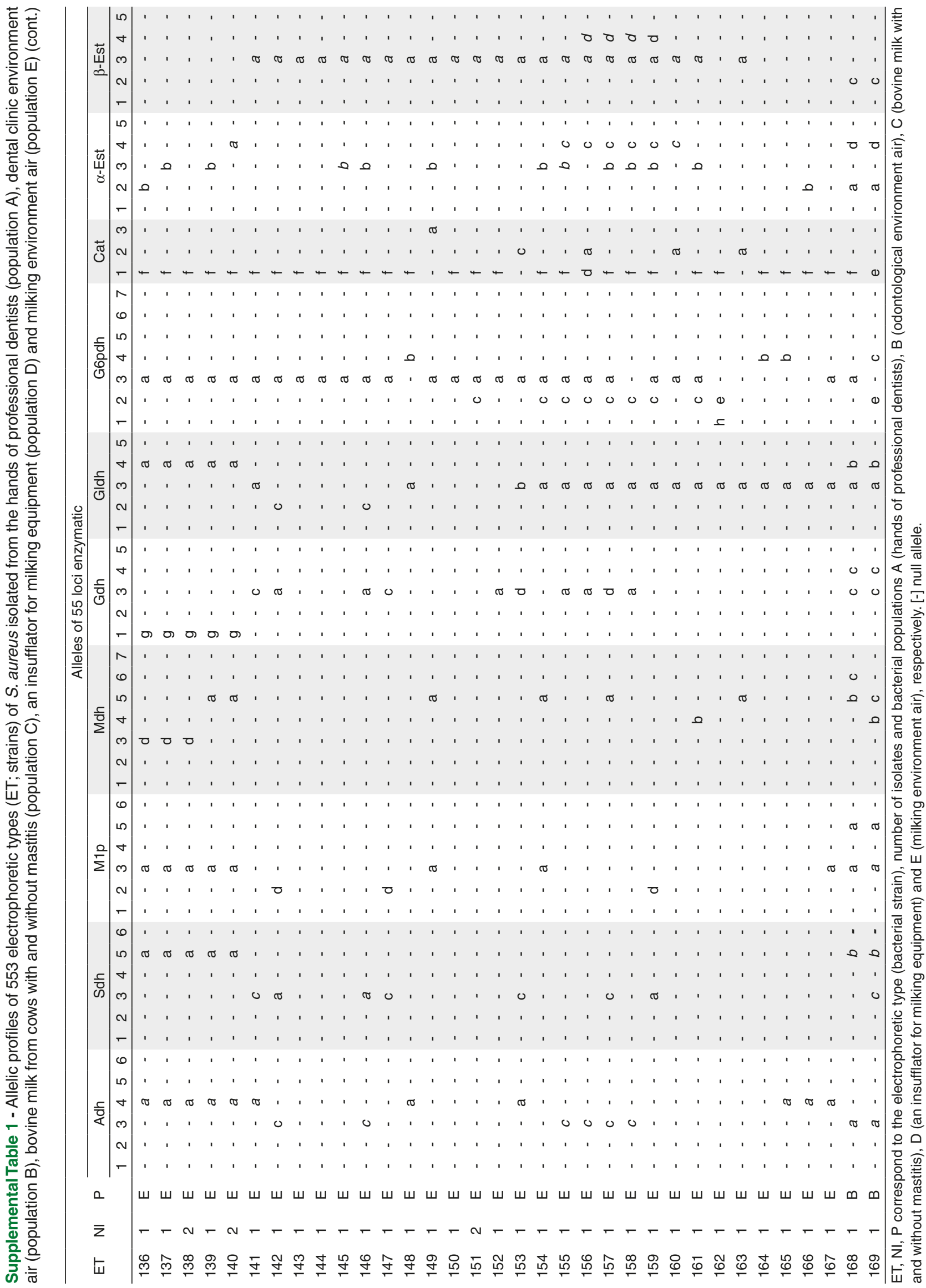




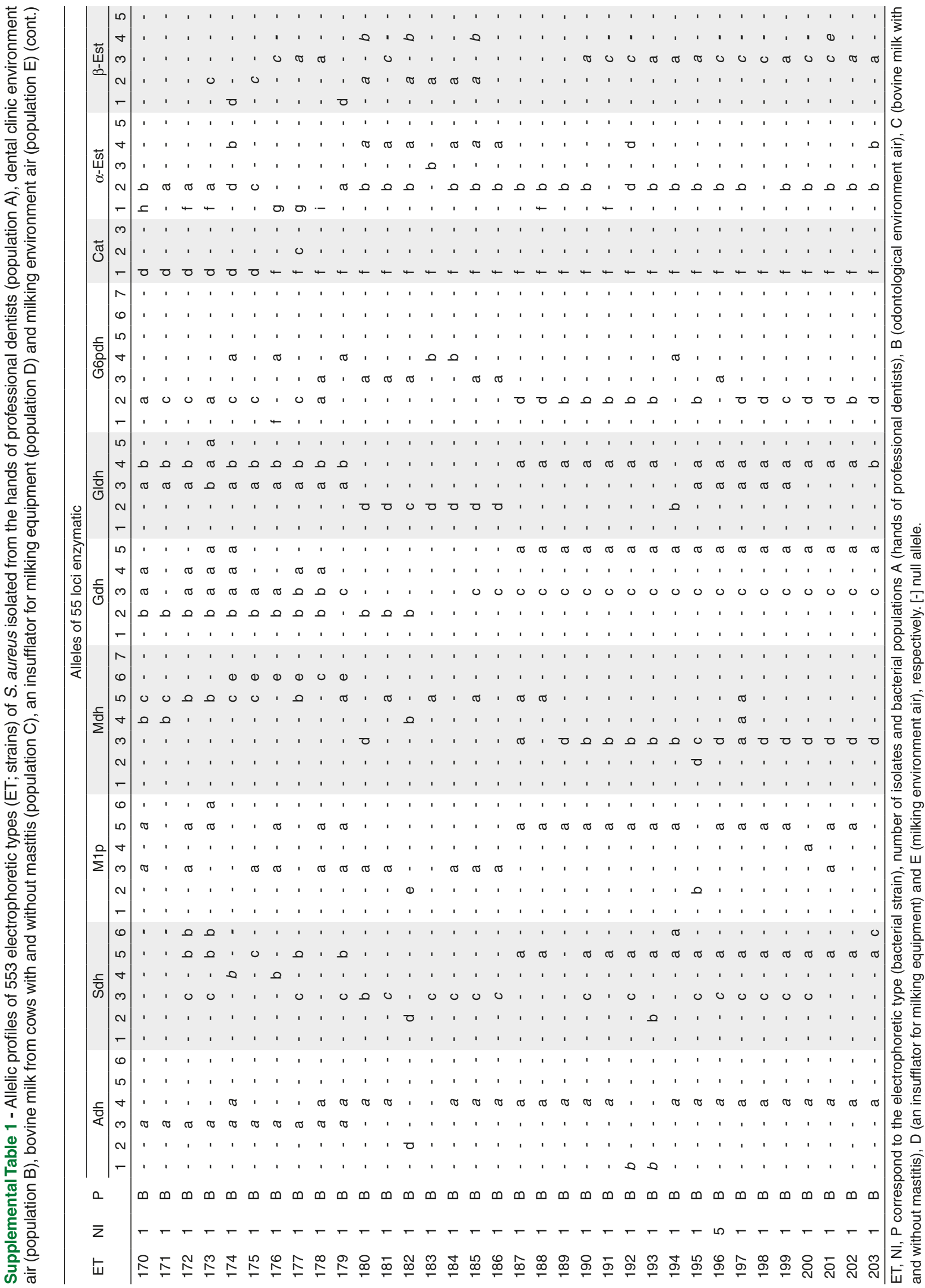




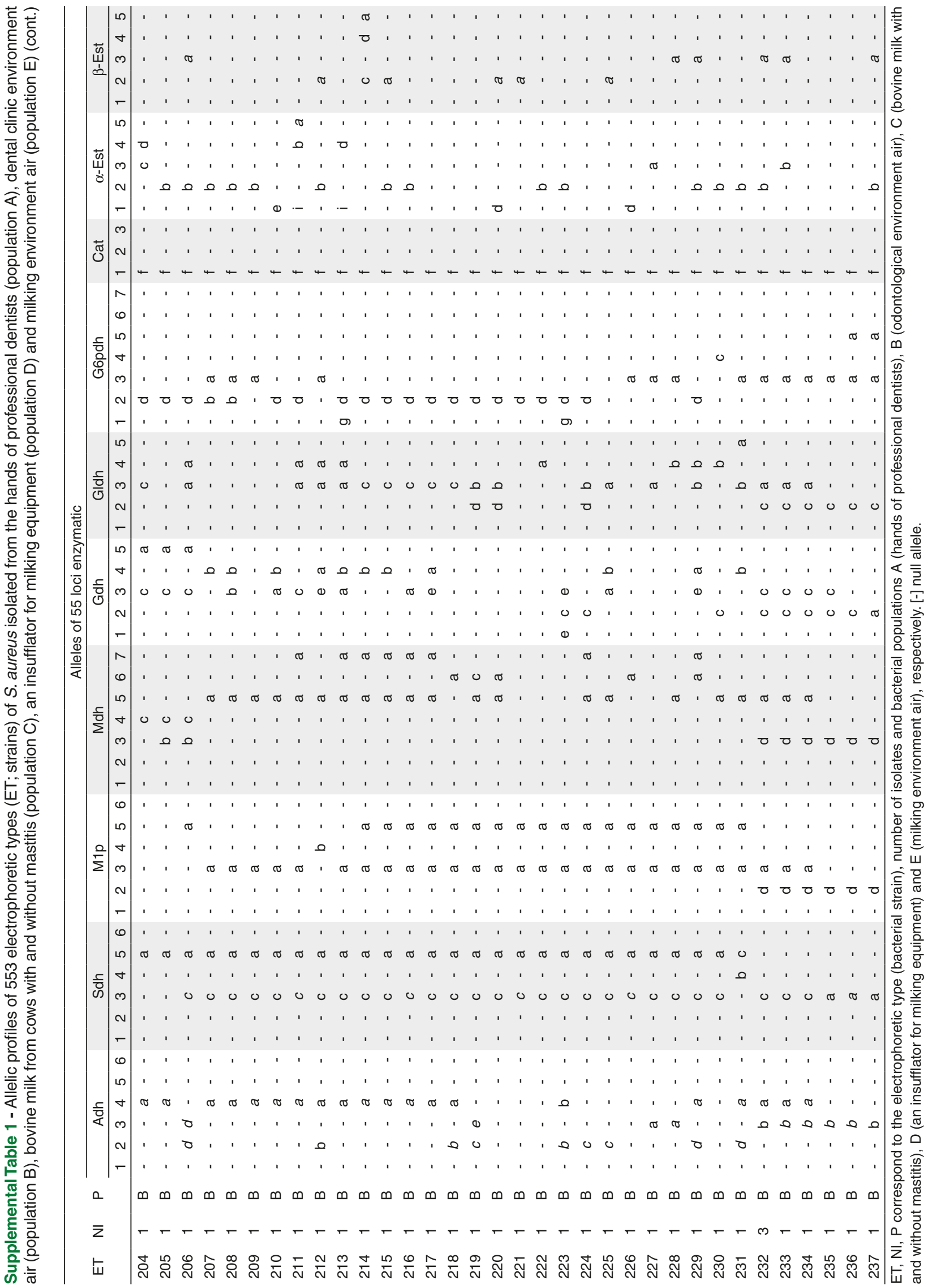




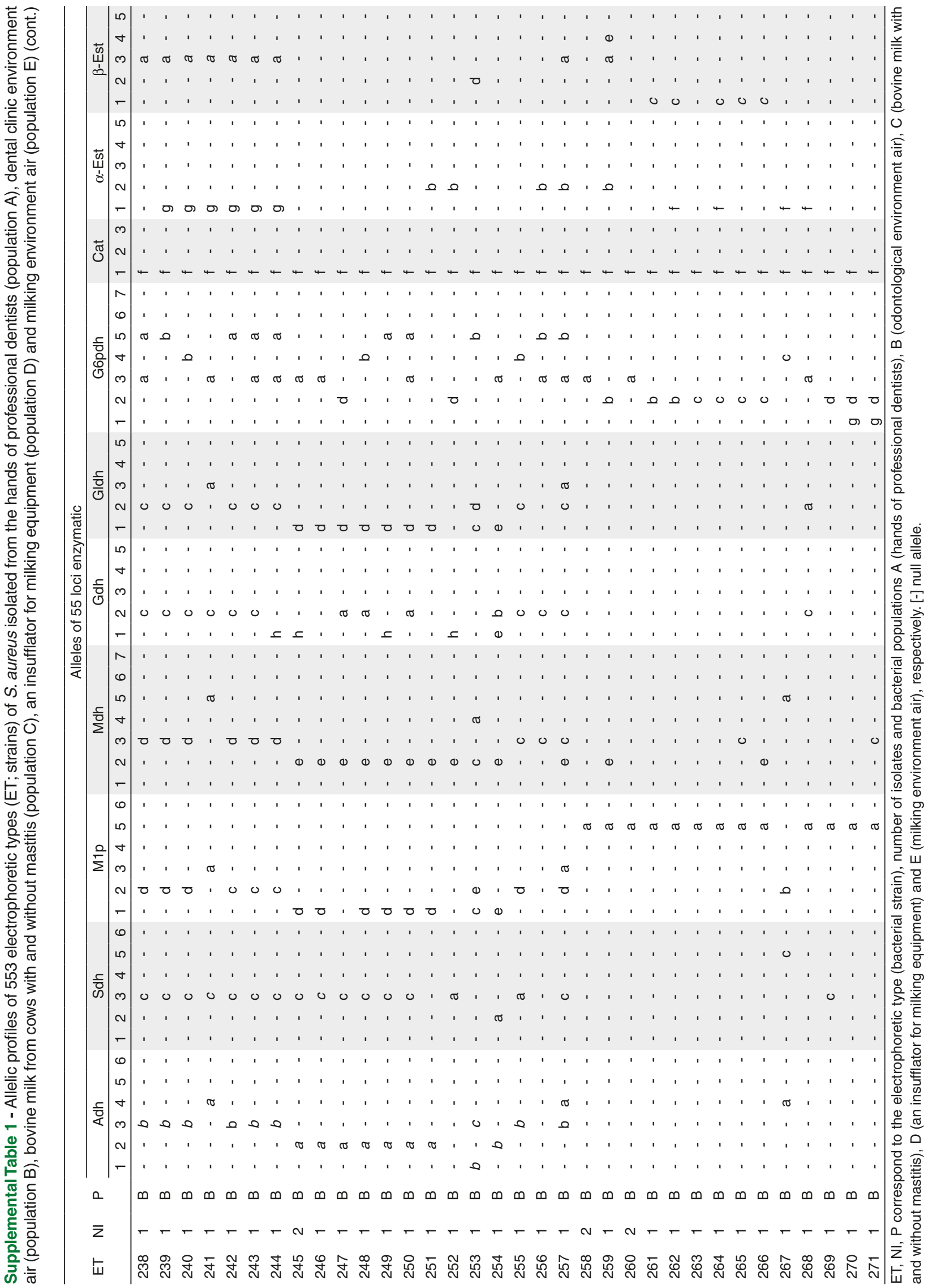




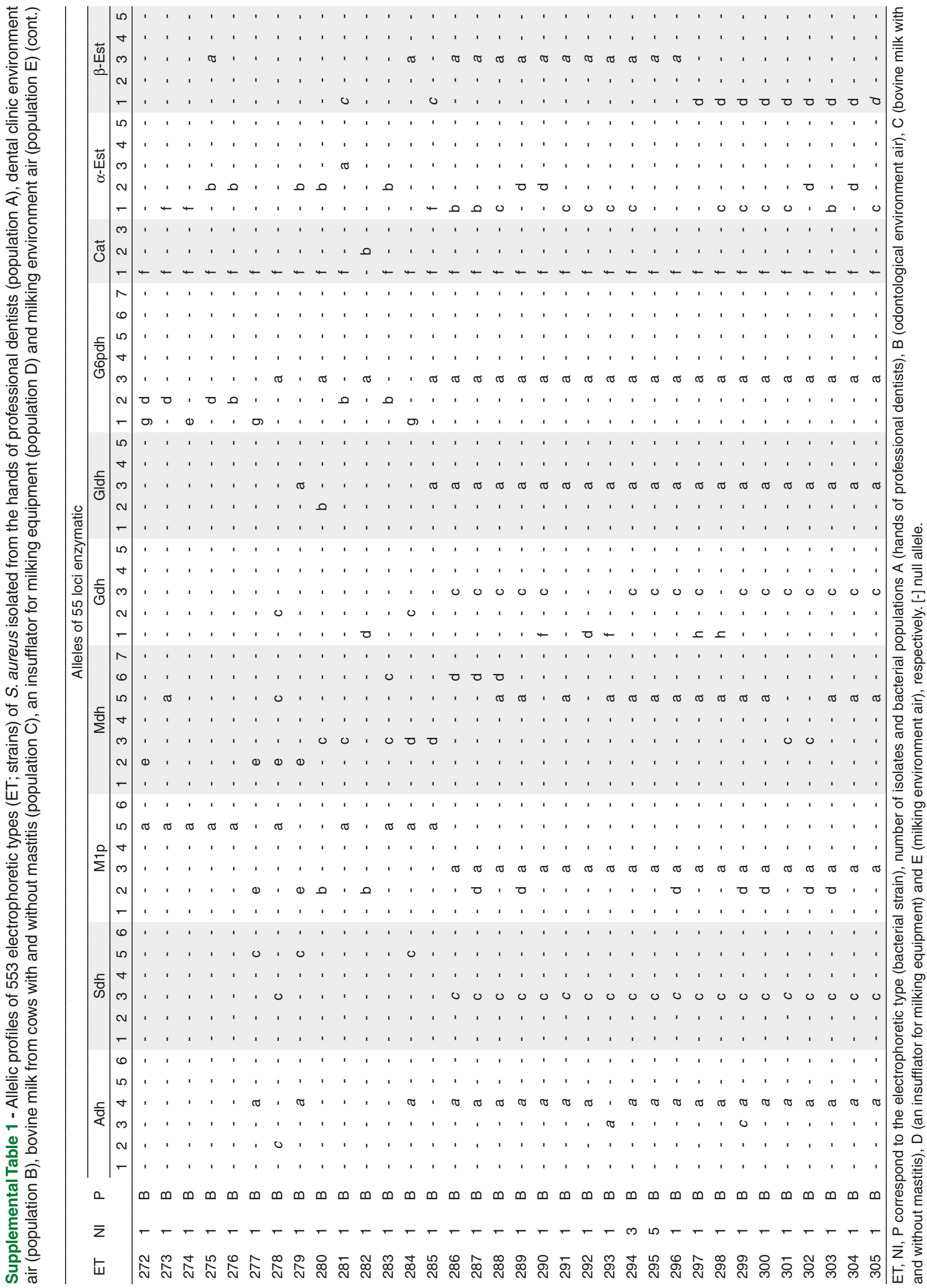




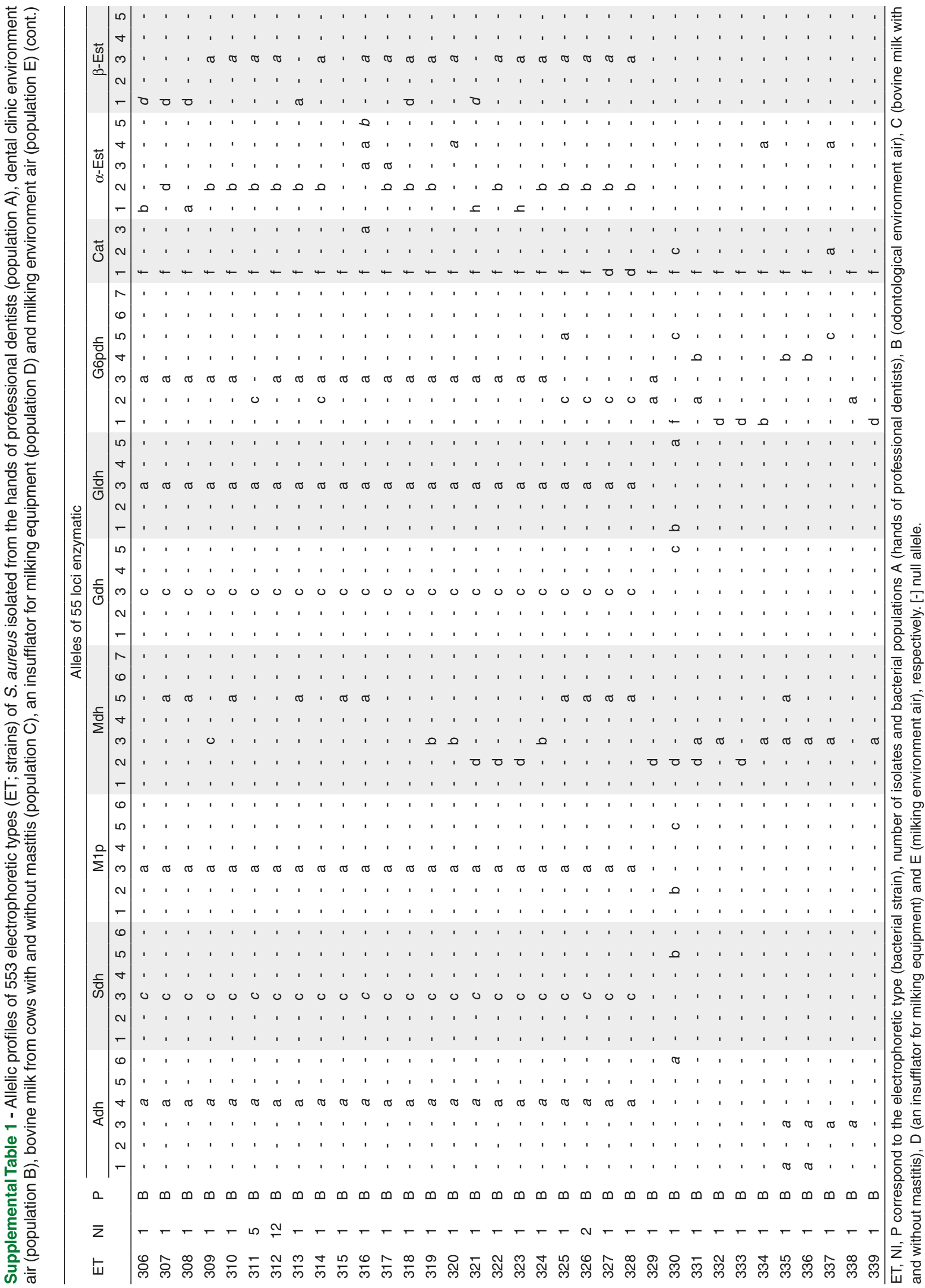




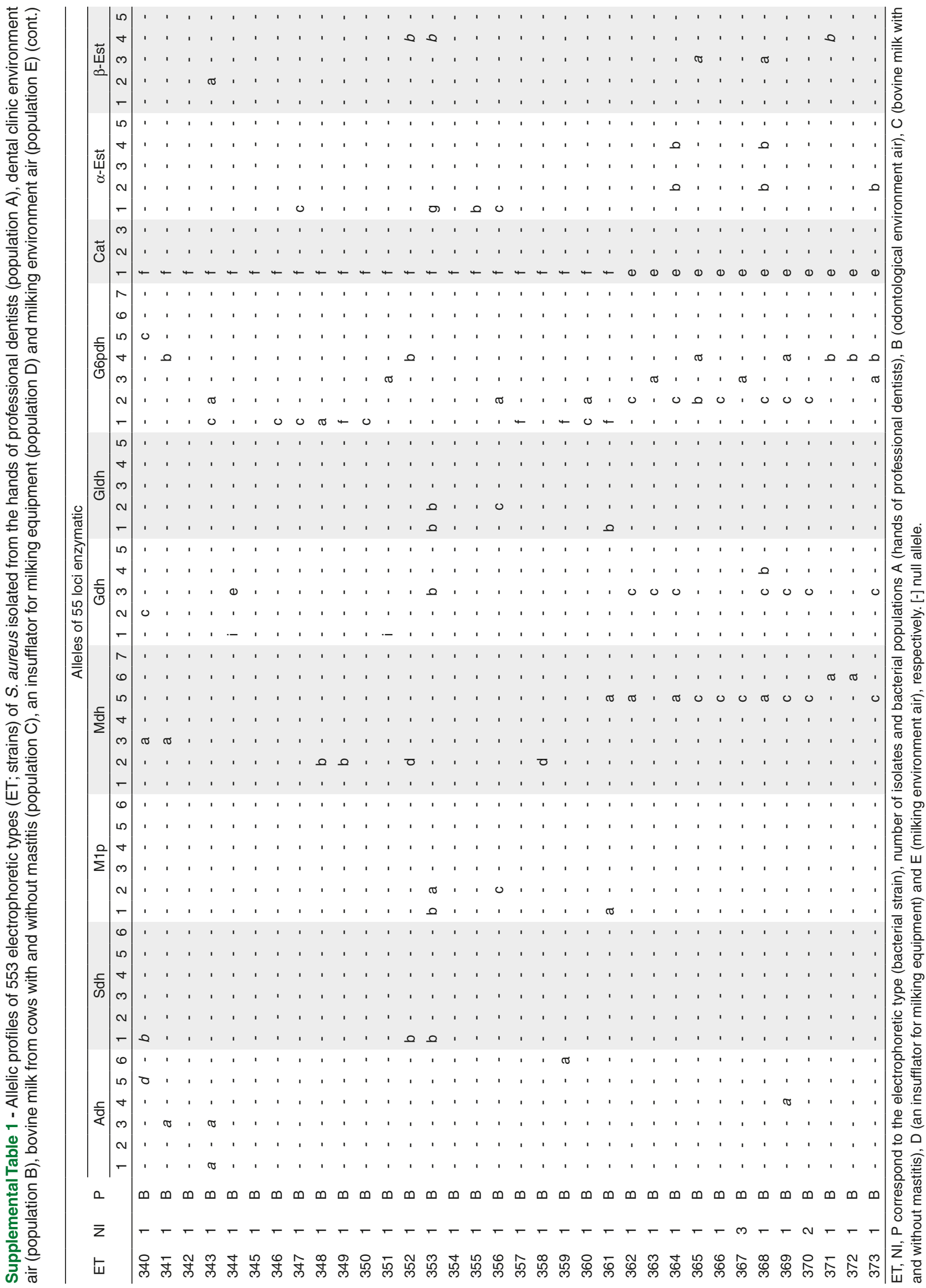




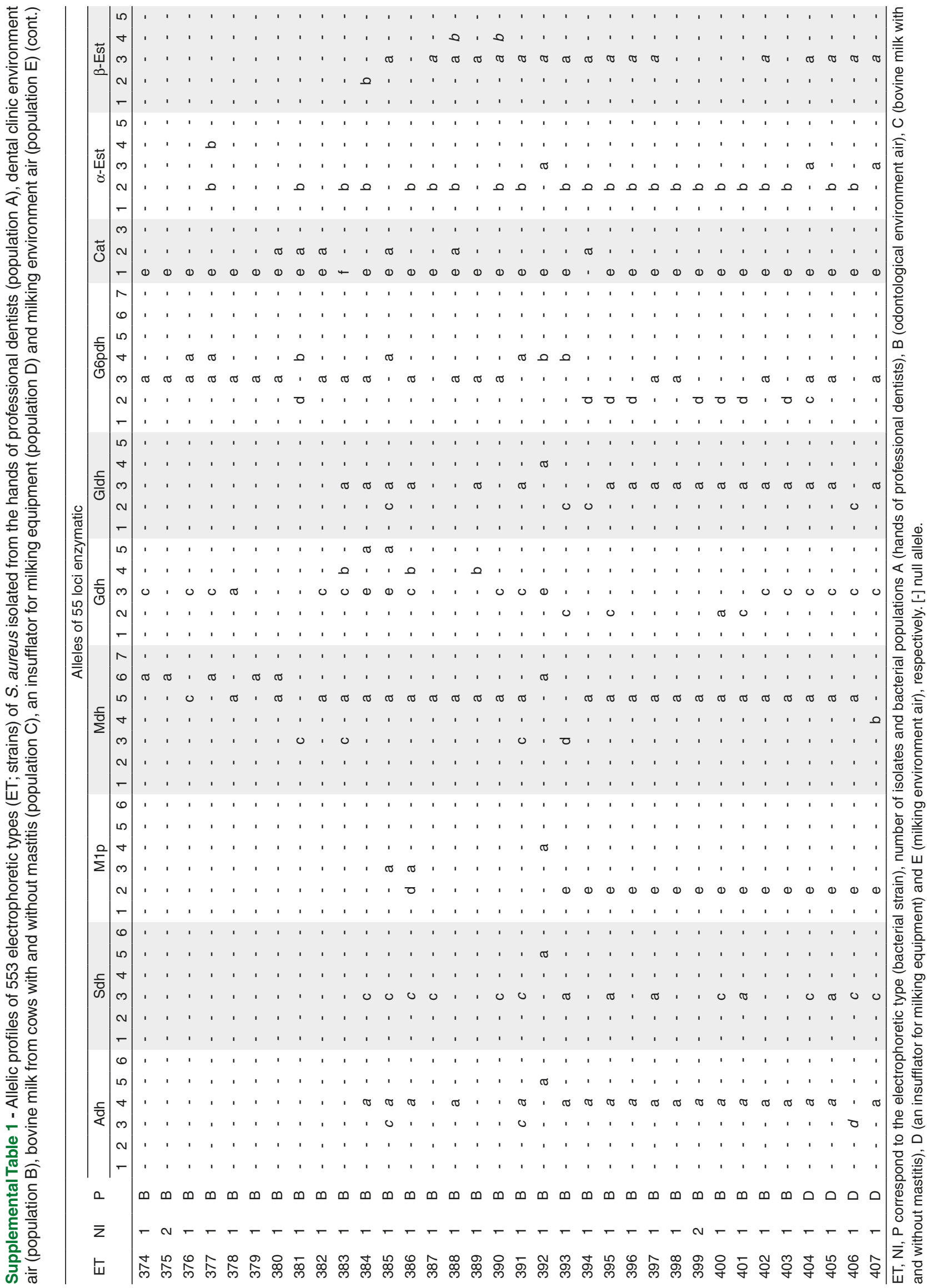




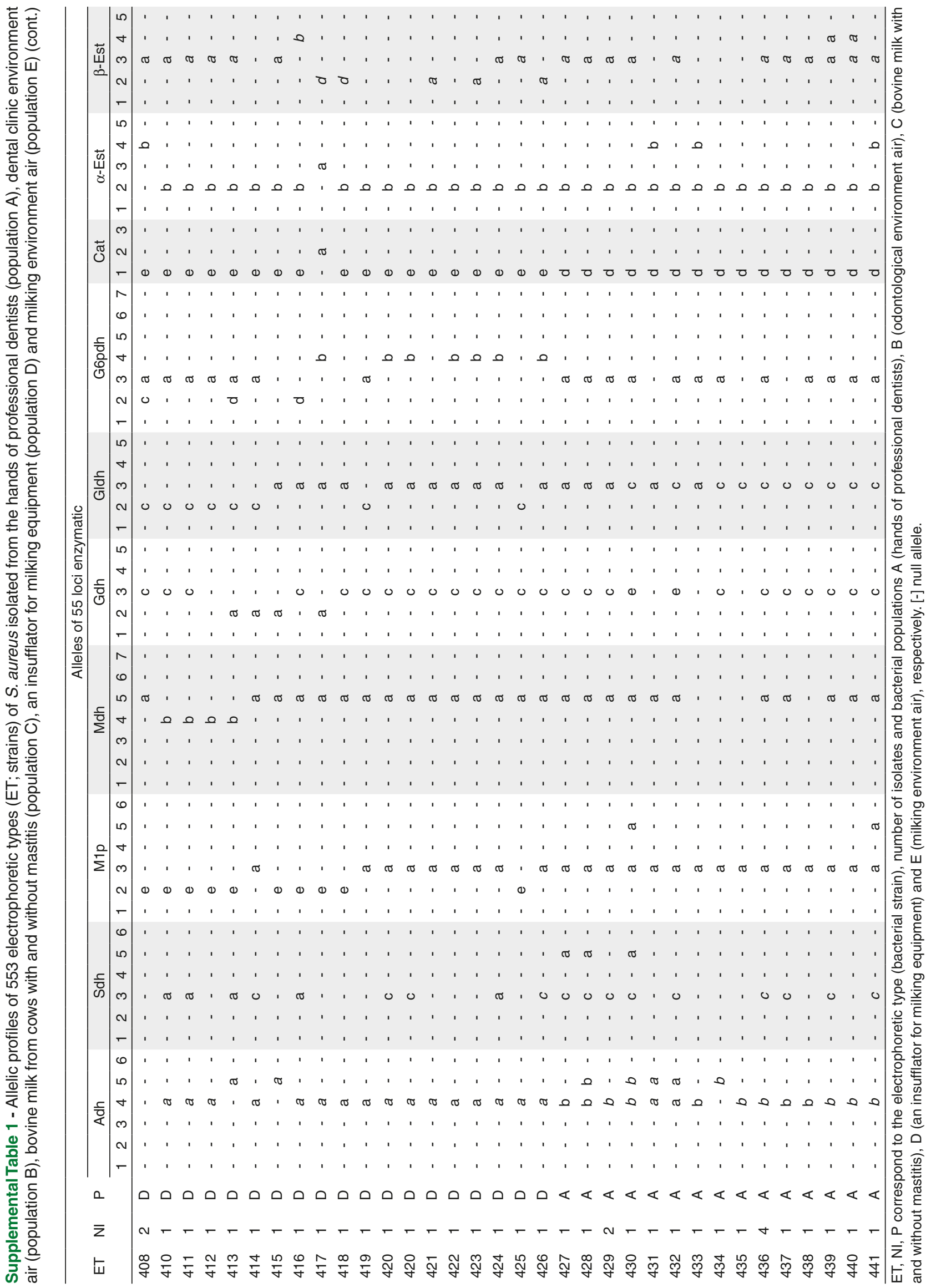




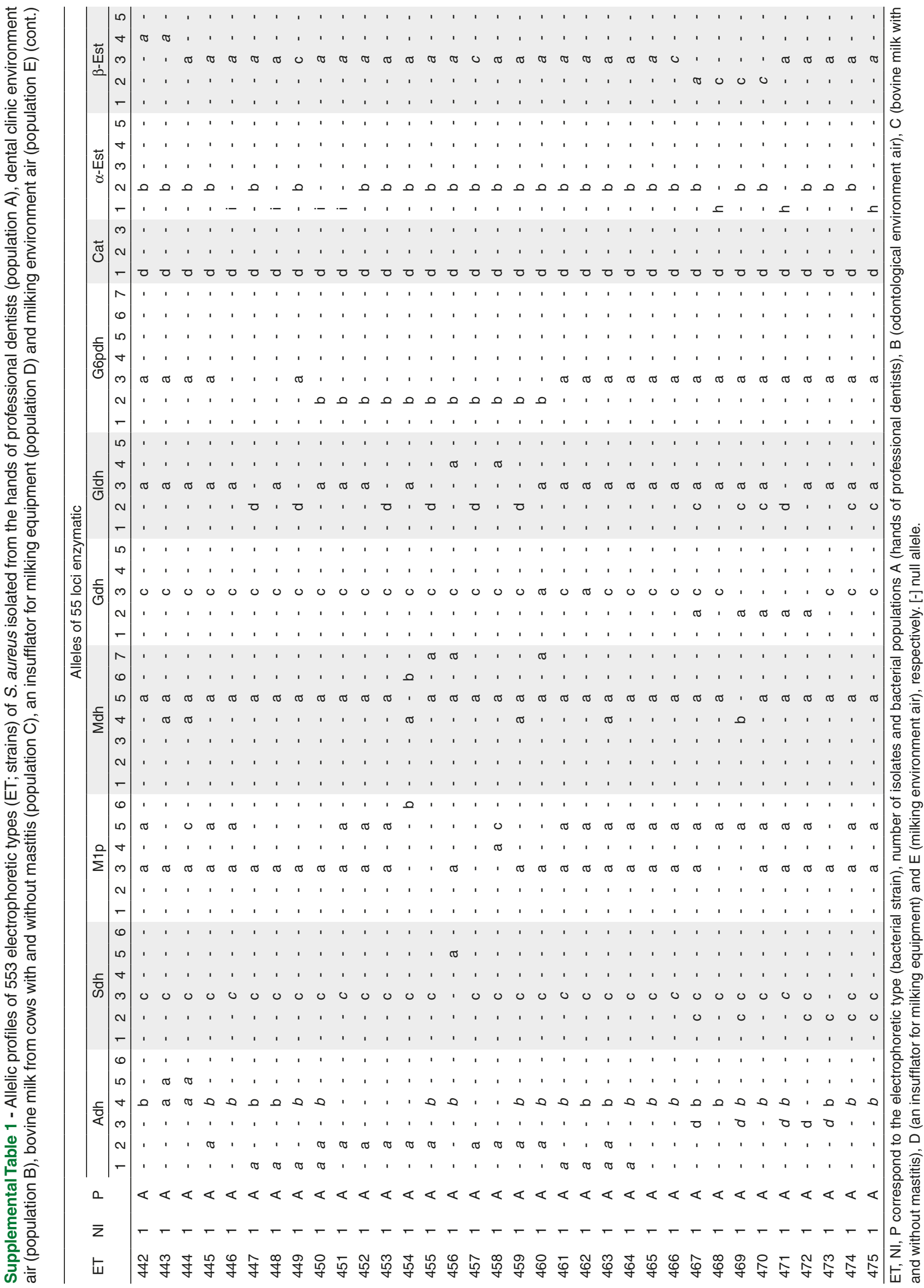




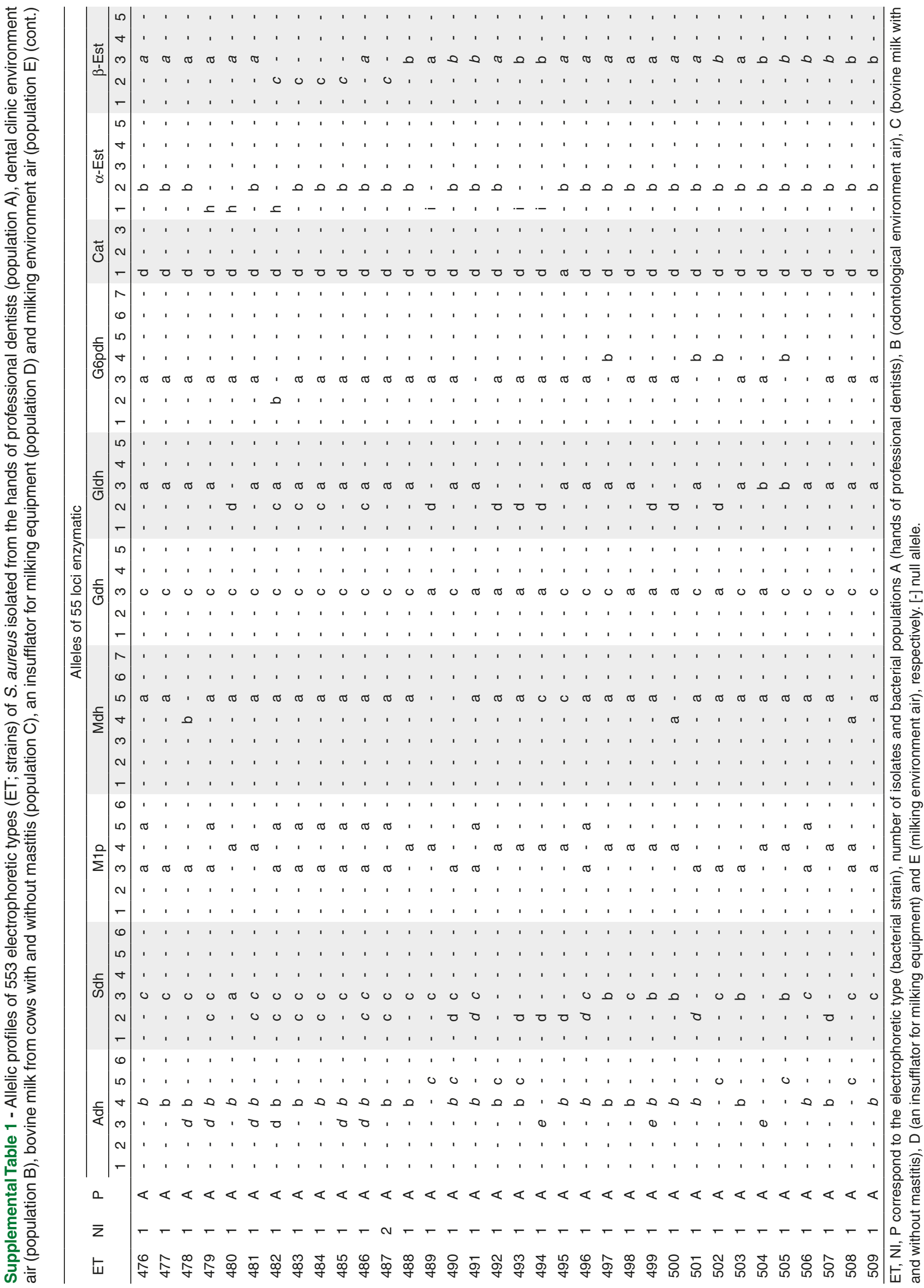




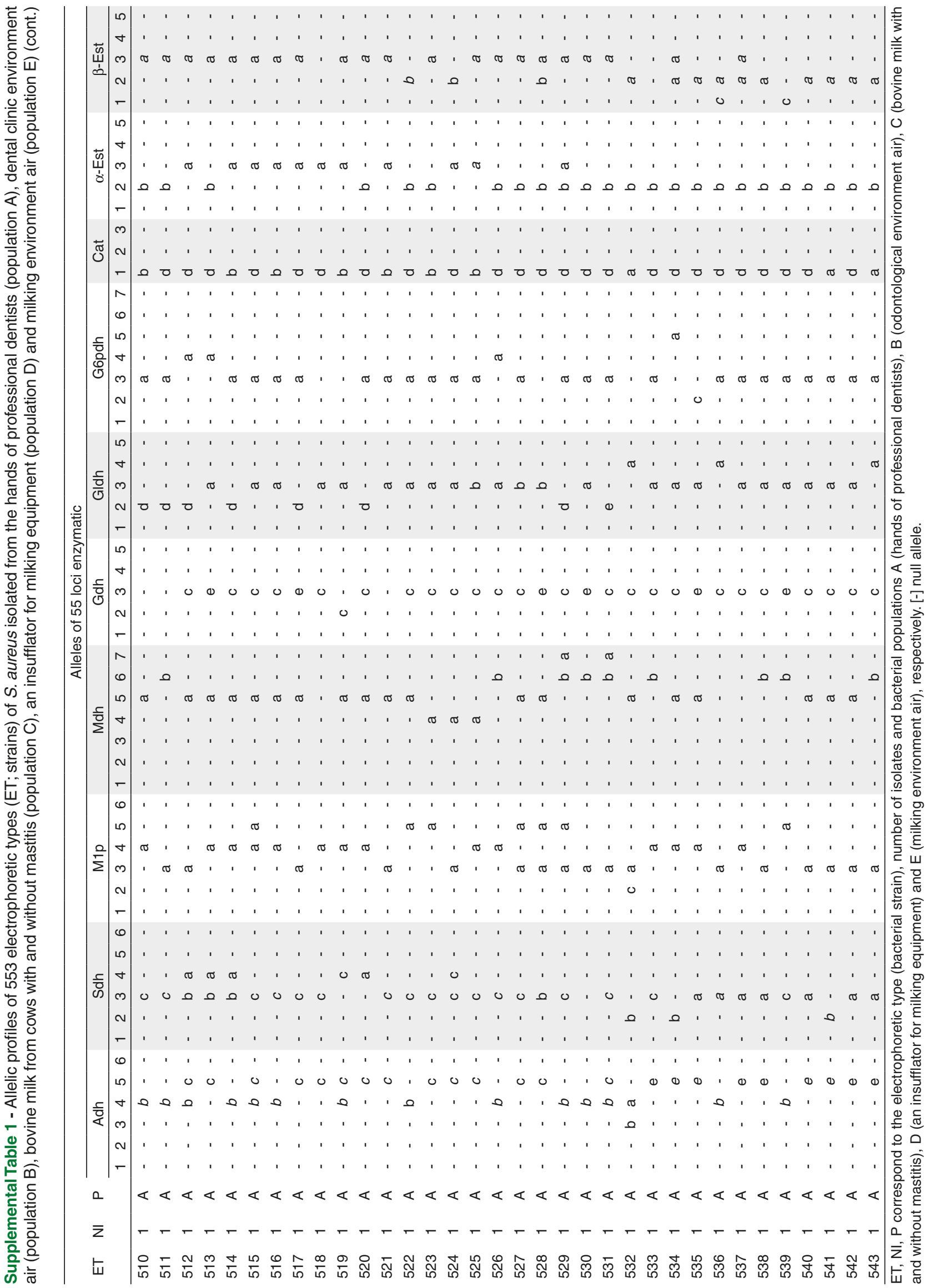




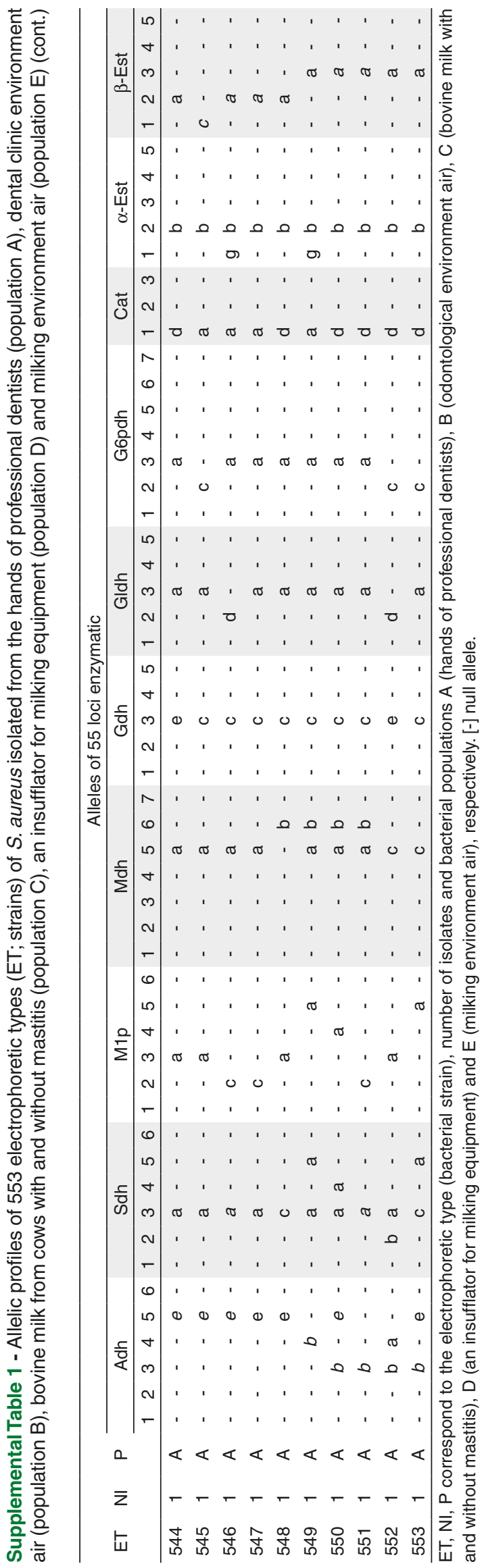


Supplemental Table 2 - Interpretation of UPGMA dendrogram generated from the genetic distance matrix (Nei, 1972) and the genetic interpretation of the MLEE patterns of $S$. aureus

\begin{tabular}{|c|c|c|c|c|c|c|c|c|c|c|c|c|c|c|c|}
\hline \multirow{3}{*}{$\begin{array}{l}\text { Taxon }^{\mathrm{a}} \\
\mathrm{I}\end{array}$} & \multirow{3}{*}{$\begin{array}{l}\text { Cluster }^{\mathrm{b}} \\
\text { or NC }^{\mathrm{c}} \\
\sum \sum\end{array}$} & \multicolumn{2}{|c|}{ Strain ${ }^{d}$} & \multicolumn{2}{|c|}{ Isolate ${ }^{e}$} & \multicolumn{10}{|c|}{ Bacterial populations ${ }^{f}$} \\
\hline & & \multirow{2}{*}{$\frac{n}{98}$} & \multirow{2}{*}{$\begin{array}{c}\% \\
17.72\end{array}$} & \multirow{2}{*}{$\begin{array}{c}n \\
126\end{array}$} & \multirow{2}{*}{$\begin{array}{c}\% \\
20.66\end{array}$} & \multicolumn{2}{|c|}{$\mathrm{A}(n$ and $\%)$} & \multicolumn{2}{|c|}{$\mathrm{B}(n$ and \%) } & \multicolumn{2}{|c|}{$\mathrm{C}(n$ and $\%)$} & \multicolumn{2}{|c|}{$\mathrm{D}(n$ and \%) } & \multicolumn{2}{|c|}{$\mathrm{E}(n$ and $\%)$} \\
\hline & & & & & & 44 & 33.33 & 70 & 25.74 & - & - & 7 & 29.17 & 5 & 3.31 \\
\hline & Cluster 1 & 52 & 9.40 & 72 & 11.80 & 32 & 24.24 & 29 & 10.66 & - & - & 7 & 29.17 & 4 & 2.65 \\
\hline & Cluster 2 & 10 & 1.81 & 15 & 2.46 & 2 & 1.52 & 13 & 4.78 & - & - & - & - & - & - \\
\hline & Cluster 3 & 2 & 0.36 & 2 & 0.33 & 2 & 1.52 & - & - & - & - & - & - & - & - \\
\hline & Cluster 4 & 3 & 0.54 & 3 & 0.49 & 3 & 2.27 & - & - & - & - & - & - & - & - \\
\hline & Cluster 5 & 4 & 0.72 & 4 & 0.66 & - & - & 4 & 1.47 & - & - & - & - & - & - \\
\hline & Cluster 6 & 2 & 0.36 & 2 & 0.33 & - & - & 2 & 0.74 & - & - & - & - & - & - \\
\hline & Cluster 7 & 2 & 0.36 & 2 & 0.33 & - & - & 2 & 0.74 & - & - & - & - & - & - \\
\hline & Cluster 8 & 3 & 0.54 & 5 & 0.82 & - & - & 5 & 1.84 & - & - & - & - & - & - \\
\hline & Cluster 9 & 3 & 0.54 & 3 & 0.49 & - & - & 3 & 1.10 & - & - & - & - & - & - \\
\hline & Cluster 10 & 7 & 1.27 & 7 & 1.15 & - & - & 7 & 2.57 & - & - & - & - & - & - \\
\hline & Cluster 11 & 5 & 0.90 & 5 & 0.82 & 2 & 1.52 & 3 & 1.10 & - & - & - & - & - & - \\
\hline & $\mathrm{NC}$ & 5 & 0.90 & 6 & 0.98 & 3 & 2.27 & 2 & 0.74 & - & - & - & - & 1 & 0.66 \\
\hline \multirow[t]{4}{*}{ II } & $\Sigma$ & 13 & 2.35 & 17 & 2.79 & - & - & 17 & 6.25 & - & - & - & - & - & - \\
\hline & Cluster 12 & 4 & 0.72 & 4 & 0.66 & - & - & 4 & 1.47 & - & - & - & - & - & - \\
\hline & Cluster 13 & 5 & 0.90 & 9 & 1.48 & - & - & 9 & 3.31 & - & - & - & - & - & - \\
\hline & $\mathrm{NC}$ & 4 & 0.72 & 4 & 0.66 & - & - & 4 & 1.47 & - & - & - & - & - & - \\
\hline \multirow[t]{5}{*}{ III } & $\Sigma$ & 10 & 1.81 & 11 & 1.80 & 11 & 8.33 & - & - & - & - & - & - & - & - \\
\hline & Cluster 14 & 4 & 0.72 & 4 & 0.66 & 4 & 3.03 & - & - & - & - & - & - & - & - \\
\hline & Cluster 15 & 3 & 0.54 & 4 & 0.66 & 4 & 3.03 & - & - & - & - & - & - & - & - \\
\hline & Cluster 16 & 2 & 0.36 & 2 & 0.33 & 2 & 1.52 & - & - & - & - & - & - & - & - \\
\hline & $\mathrm{NC}$ & 1 & 0.18 & 1 & 0.16 & 1 & 0.76 & - & - & - & - & - & - & - & - \\
\hline \multirow[t]{8}{*}{ IV } & $\Sigma$ & 55 & 9.95 & 62 & 10.16 & 3 & 2.27 & 34 & 12.50 & - & - & - & - & 25 & 16.56 \\
\hline & Cluster 17 & 11 & 1.99 & 13 & 2.13 & - & - & 3 & 1.10 & - & - & - & - & 10 & 6.62 \\
\hline & Cluster 18 & 30 & 5.42 & 33 & 5.41 & - & - & $2-$ & 7.35 & - & - & - & - & 13 & 8.61 \\
\hline & Cluster 19 & 3 & 0.54 & 5 & 0.82 & - & - & 5 & 1.84 & - & - & - & - & - & - \\
\hline & Cluster 20 & 2 & 0.36 & 2 & 0.33 & - & - & 1 & 0.37 & - & - & - & - & 1 & 0.66 \\
\hline & Cluster 21 & 3 & 0.54 & 3 & 0.49 & - & - & 3 & 1.10 & - & - & - & - & - & - \\
\hline & Cluster 22 & 3 & 0.54 & 3 & 0.49 & 3 & 2.27 & - & - & - & - & - & - & - & - \\
\hline & $\mathrm{NC}$ & 3 & 0.54 & 3 & 0.49 & - & - & 2 & 0.74 & - & - & - & - & 1 & 0.66 \\
\hline \multirow[t]{5}{*}{ V } & $\Sigma$ & 16 & 2.89 & 17 & 2.79 & 1 & 0.76 & 15 & 5.51 & - & - & - & - & 1 & 0.66 \\
\hline & Cluster 23 & 2 & 0.36 & 2 & 0.33 & - & - & 2 & 0.74 & - & - & - & - & - & - \\
\hline & Cluster 24 & 5 & 0.90 & 6 & 0.98 & - & - & 6 & 2.21 & - & - & - & - & - & - \\
\hline & Cluster 25 & 6 & 1.08 & 6 & 0.98 & - & - & 6 & 2.21 & - & - & - & - & - & - \\
\hline & $\mathrm{NC}$ & 3 & 0.54 & 3 & 0.49 & 1 & 0.76 & 1 & 0.37 & - & - & - & - & 1 & 0.66 \\
\hline $\mathrm{VI}$ & $\Sigma$ & 14 & 2.53 & 14 & 2.30 & - & - & 7 & 2.57 & - & - & - & - & 7 & 4.64 \\
\hline & Cluster 26 & 7 & 1.27 & 7 & 1.15 & - & - & - & - & - & - & - & - & 7 & 4.64 \\
\hline & Cluster 27 & 6 & 1.08 & 6 & 0.98 & - & - & 6 & 2.21 & - & - & - & - & - & - \\
\hline & $\mathrm{NC}$ & 1 & 0.18 & 1 & 0.16 & - & - & 1 & 0.37 & - & - & - & - & - & - \\
\hline VII & $\Sigma$ & 1 & 0.18 & 1 & 0.16 & - & - & 1 & 0.37 & - & - & - & - & - & - \\
\hline & $\mathrm{NC}$ & 1 & 0.18 & 1 & 0.16 & - & - & 1 & 0.37 & - & - & - & - & - & - \\
\hline VIII & $\Sigma$ & 2 & 0.36 & 2 & 0.33 & - & - & 1 & 0.37 & - & - & - & - & 1 & 0.66 \\
\hline & Cluster 28 & 2 & 0.36 & 2 & 0.33 & - & - & 1 & 0.37 & - & - & - & - & 1 & 0.66 \\
\hline $\mathrm{IX}$ & $\sum$ & 2 & 0.36 & 2 & 0.33 & - & - & 2 & 0.74 & - & - & - & - & - & - \\
\hline & $\mathrm{NC}$ & 2 & 0.36 & 2 & 0.33 & - & - & 2 & 0.74 & - & - & - & - & - & - \\
\hline
\end{tabular}

a Taxa are genetically related to distance $\left(d_{i j}>0.1175\right)$ and each taxon displays clustered isolates and/or non-clustered isolates. ${ }^{b}$ Cluster comprised two or more bacterial isolates interpreted as identical or highly related isolates/strains $\left(0.0551>d_{i j} \geq 0\right) .{ }^{c} \mathrm{NC}$ : non-clustered isolates or strains $\left(0.0551<d_{i j} \leq 0.3810\right) .{ }^{d}$ Number and percentage of strains per Cluster. strain refers to a collection of isolates of the same species that are genetically indistinguishable. e Number and percentage of isolates per Cluster. an isolate is defined as a clone collected independently of other isolates. Two independently collected isolates may be completely unrelated (different strains) or genetically indistinguishable (same strain). ${ }^{f}$ Number and percentage of isolates per bacterial population (A, $B, C, D$ and $E)$. 
Supplemental Table 2 - Interpretation of UPGMA dendrogram generated from the genetic distance matrix (Nei, 1972) and the genetic interpretation of the MLEE patterns of $S$. aureus (cont.)

\begin{tabular}{|c|c|c|c|c|c|c|c|c|c|c|c|c|c|c|c|}
\hline \multirow{3}{*}{$\begin{array}{l}\text { Taxon }^{\text {a }} \\
\mathrm{X}\end{array}$} & \multirow{3}{*}{$\begin{array}{l}\text { Cluster }^{\text {b }} \\
\text { or NC }^{\mathrm{c}} \\
\sum\end{array}$} & \multicolumn{2}{|c|}{ Strain $^{d}$} & \multicolumn{2}{|c|}{ Isolate $^{e}$} & \multicolumn{10}{|c|}{ Bacterial populations $^{f}$} \\
\hline & & \multirow{2}{*}{$\frac{n}{25}$} & \multirow{2}{*}{$\begin{array}{c}\% \\
4.52\end{array}$} & \multirow{2}{*}{$\frac{n}{25}$} & \multirow{2}{*}{$\frac{\%}{4.10}$} & \multicolumn{2}{|c|}{$\mathrm{A}(n$ and $\%)$} & \multicolumn{2}{|c|}{$\mathrm{B}(n$ and $\%)$} & \multicolumn{2}{|c|}{$\mathrm{C}(n$ and $\%)$} & \multicolumn{2}{|c|}{$\mathrm{D}(n$ and $\%)$} & \multicolumn{2}{|c|}{$\mathrm{E}(n$ and $\%)$} \\
\hline & & & & & & 18 & 13.64 & 5 & 1.84 & - & - & 2 & 8.33 & - & - \\
\hline & Cluster 29 & 5 & 0.90 & 5 & 0.82 & 3 & 2.27 & 1 & 0.37 & - & - & 1 & 4.17 & - & - \\
\hline & Cluster 30 & 3 & 0.54 & 3 & 0.49 & - & - & 2 & 0.74 & - & - & 1 & 4.17 & - & - \\
\hline & Cluster 31 & 8 & 1.45 & 8 & 1.31 & 8 & 6.06 & - & - & - & - & - & - & - & - \\
\hline & Cluster 32 & 2 & 0.36 & 2 & 0.33 & - & - & 2 & 0.74 & - & - & - & - & - & - \\
\hline & Cluster 33 & 2 & 0.36 & 2 & 0.33 & 2 & 1.52 & - & - & - & - & - & - & - & - \\
\hline & Cluster 34 & 2 & 0.36 & 2 & 0.33 & 2 & 1.52 & - & - & - & - & - & - & - & - \\
\hline & $\mathrm{NC}$ & 3 & 0.54 & 3 & 0.49 & 3 & 2.27 & - & - & - & - & - & - & - & - \\
\hline \multirow[t]{2}{*}{ XI } & $\sum$ & 2 & 0.36 & 2 & 0.33 & 1 & 0.76 & 1 & 0.37 & - & - & - & - & - & - \\
\hline & $\mathrm{NC}$ & 2 & 0.36 & 2 & 0.33 & 1 & 0.76 & 1 & 0.37 & - & - & - & - & - & - \\
\hline \multirow[t]{4}{*}{ XII } & $\Sigma$ & 5 & 0.90 & 6 & 0.98 & - & - & - & - & - & - & - & - & 6 & 3.97 \\
\hline & Cluster 35 & 1 & 0.18 & 2 & 0.33 & - & - & - & - & - & - & - & - & 2 & 1.32 \\
\hline & Cluster 36 & 2 & 0.36 & 2 & 0.33 & - & - & - & - & - & - & - & - & 2 & 1.32 \\
\hline & NC & 2 & 0.36 & 2 & 0.33 & - & - & - & - & - & - & - & - & 2 & 1.32 \\
\hline \multirow[t]{4}{*}{$\overline{\mathrm{XIII}}$} & $\Sigma$ & 12 & 2.17 & 12 & 1.97 & 10 & 7.58 & 1 & 0.37 & - & - & - & - & 1 & 0.66 \\
\hline & Cluster 37 & 2 & 0.36 & 2 & 0.33 & 2 & 1.52 & - & - & - & - & - & - & - & - \\
\hline & Cluster 38 & 4 & 0.72 & 4 & 0.66 & 4 & 3.03 & - & - & - & - & - & - & - & - \\
\hline & $\mathrm{NC}$ & 6 & 1.08 & 6 & 0.98 & 4 & 3.03 & 1 & 0.37 & - & - & - & - & 1 & 0.66 \\
\hline \multirow[t]{2}{*}{ XIV } & $\Sigma$ & 1 & 0.18 & 1 & 0.16 & 1 & 0.76 & - & - & - & - & - & - & - & - \\
\hline & $\mathrm{NC}$ & 1 & 0.18 & 1 & 0.16 & 1 & 0.76 & - & - & - & - & - & - & - & - \\
\hline $\mathrm{XV}$ & $\Sigma$ & 1 & 0.18 & 1 & 0.16 & - & - & - & - & 1 & 3.23 & - & - & - & - \\
\hline & $\mathrm{NC}$ & 1 & 0.18 & 1 & 0.16 & - & - & - & - & 1 & 3.23 & - & - & - & - \\
\hline $\mathrm{XVI}$ & $\Sigma$ & 5 & 0.90 & 7 & 1.15 & - & - & - & - & 7 & 22.58 & - & - & - & - \\
\hline & Cluster 39 & 5 & 0.90 & 7 & 1.15 & - & - & - & - & 7 & 22.58 & - & - & - & - \\
\hline XVII & $\Sigma$ & 7 & 1.27 & 7 & 1.15 & - & - & - & - & 7 & 22.58 & - & - & - & - \\
\hline & Cluster 40 & 4 & 0.72 & 4 & 0.66 & - & - & - & - & 4 & 12.90 & - & - & - & - \\
\hline & $\mathrm{NC}$ & 3 & 0.54 & 3 & 0.49 & - & - & - & - & 3 & 9.68 & - & - & - & - \\
\hline XVIII & $\Sigma$ & 1 & 0.18 & 1 & 0.16 & - & - & 1 & 0.37 & - & - & - & - & - & - \\
\hline & $\mathrm{NC}$ & 1 & 0.18 & 1 & 0.16 & - & - & 1 & 0.37 & - & - & - & - & - & - \\
\hline XIX & $\Sigma$ & 1 & 0.18 & 1 & 0.16 & - & - & - & - & - & - & - & - & 1 & 0.66 \\
\hline & $\mathrm{NC}$ & 1 & 0.18 & 1 & 0.16 & - & - & - & - & - & - & - & - & 1 & 0.66 \\
\hline$X X$ & $\Sigma$ & 1 & 0.18 & 1 & 0.16 & - & - & 1 & 0.37 & - & - & - & - & - & - \\
\hline & $\mathrm{NC}$ & 1 & 0.18 & 1 & 0.16 & - & - & 1 & 0.37 & - & - & - & - & - & - \\
\hline$\overline{X X I}$ & $\sum$ & 26 & 4.70 & 26 & 4.26 & 26 & 19.70 & - & - & - & - & - & - & - & - \\
\hline & Cluster 41 & 9 & 1.63 & 9 & 1.48 & 9 & 6.82 & - & - & - & - & - & - & - & - \\
\hline & Cluster 42 & 10 & 1.81 & 10 & 1.64 & 10 & 7.58 & - & - & - & - & - & - & - & - \\
\hline & Cluster 43 & 2 & 0.36 & 2 & 0.33 & 2 & 1.52 & - & - & - & - & - & - & - & - \\
\hline & $\mathrm{NC}$ & 5 & 0.90 & 5 & 0.82 & 5 & 3.79 & - & - & - & - & - & - & - & - \\
\hline XXII & $\sum$ & 21 & 3.80 & 21 & 3.44 & 1 & 0.76 & 6 & 2.21 & 1 & 3.23 & 10 & 41.67 & 2 & 1.32 \\
\hline & Cluster 44 & 2 & 0.36 & 2 & 0.33 & - & - & - & - & - & - & 1 & 4.17 & 1 & 0.66 \\
\hline & Cluster 45 & 6 & 1.08 & 6 & 0.98 & - & - & 3 & 1.10 & - & - & 1 & 4.17 & 1 & 0.66 \\
\hline & Cluster 46 & 5 & 0.90 & 5 & 0.82 & - & - & 3 & 1.10 & - & - & 2 & 8.33 & - & - \\
\hline & Cluster 47 & 5 & 0.90 & 5 & 0.82 & - & - & - & - & - & - & 5 & 20.83 & - & - \\
\hline & NC & 3 & 0.54 & 3 & 0.49 & 1 & 0.76 & - & - & 1 & 3.23 & 1 & 4.17 & - & - \\
\hline XXIII & $\sum$ & 9 & 1.63 & 10 & 1.64 & - & - & 7 & 2.57 & - & - & 3 & 12.50 & - & - \\
\hline
\end{tabular}

a Taxa are genetically related to distance $\left(d_{i j}>0.1175\right)$ and each taxon displays clustered isolates and/or non-clustered isolates. ${ }^{b}$ Cluster comprised two or more bacterial isolates interpreted as identical or highly related isolates/strains $\left(0.0551>d_{i j} \geq 0\right) .{ }^{c} \mathrm{NC}$ : non-clustered isolates or strains $\left(0.0551<d_{i j} \leq 0.3810\right) .{ }^{d}$ Number and percentage of strains per Cluster. strain refers to a collection of isolates of the same species that are genetically indistinguishable. ${ }^{e}$ Number and percentage of isolates per Cluster. an isolate is defined as a clone collected independently of other isolates. Two independently collected isolates may be completely unrelated (different strains) or genetically indistinguishable (same strain). ${ }^{\dagger}$ Number and percentage of isolates per bacterial population (A, $B, C, D$ and $E)$. 
Supplemental Table 2 - Interpretation of UPGMA dendrogram generated from the genetic distance matrix (Nei, 1972) and the genetic interpretation of the MLEE patterns of $S$. aureus (cont.)

\begin{tabular}{|c|c|c|c|c|c|c|c|c|c|c|c|c|c|c|c|}
\hline \multirow[t]{3}{*}{$\overline{\text { Taxon }^{\mathrm{a}}}$} & \multirow{3}{*}{$\begin{array}{l}\text { Cluster }^{\text {b }} \\
\text { or NC }^{\text {c }}\end{array}$} & \multicolumn{2}{|c|}{ Strain $^{d}$} & \multicolumn{2}{|c|}{ Isolate ${ }^{\mathrm{e}}$} & \multicolumn{10}{|c|}{ Bacterial populations $^{f}$} \\
\hline & & \multirow{2}{*}{$\begin{array}{l}n \\
7\end{array}$} & \multirow{2}{*}{$\begin{array}{c}\% \\
1.27\end{array}$} & \multirow{2}{*}{$\begin{array}{l}n \\
8\end{array}$} & \multirow{2}{*}{$\begin{array}{c}\% \\
1.31\end{array}$} & \multicolumn{2}{|c|}{$\mathrm{A}(n$ and $\%)$} & \multicolumn{2}{|c|}{$\mathrm{B}(n$ and $\%)$} & \multicolumn{2}{|c|}{$\mathrm{C}(n$ and $\%)$} & \multicolumn{2}{|c|}{$\mathrm{D}(n$ and \%) } & \multicolumn{2}{|c|}{$\mathrm{E}(n$ and $\%)$} \\
\hline & & & & & & - & - & 7 & 2.57 & - & - & 1 & 4.17 & - & - \\
\hline & NC & 2 & 0.36 & 2 & 0.33 & - & - & - & - & - & - & 2 & 8.33 & - & - \\
\hline \multirow[t]{4}{*}{ XXIV } & $\sum$ & 13 & 2.35 & 15 & 2.46 & - & - & 15 & 5.51 & - & - & - & - & - & - \\
\hline & Cluster 49 & 8 & 1.45 & 10 & 1.64 & - & - & 10 & 3.68 & - & - & - & - & - & - \\
\hline & Cluster 50 & 2 & 0.36 & 2 & 0.33 & - & - & 2 & 0.74 & - & - & - & - & - & - \\
\hline & NC & 3 & 0.54 & 3 & 0.49 & - & - & 3 & 1.10 & - & - & - & - & - & - \\
\hline \multirow[t]{2}{*}{$X X V$} & $\Sigma$ & 1 & 0.18 & 1 & 0.16 & - & - & 1 & 0.37 & - & - & - & - & - & - \\
\hline & $\mathrm{NC}$ & 1 & 0.18 & 1 & 0.16 & - & - & 1 & 0.37 & - & - & - & - & - & - \\
\hline \multirow[t]{3}{*}{ XXVI } & $\Sigma$ & 5 & 0.90 & 5 & 0.82 & - & - & - & - & - & - & - & - & 5 & 3.31 \\
\hline & Cluster 51 & 3 & 0.54 & 3 & 0.49 & - & - & - & - & - & - & - & - & 3 & 1.99 \\
\hline & $\mathrm{NC}$ & 2 & 0.36 & 2 & 0.33 & - & - & - & - & - & - & - & - & 2 & 1.32 \\
\hline \multirow[t]{2}{*}{ XXVII } & $\Sigma$ & 1 & 0.18 & 1 & 0.16 & - & - & 1 & 0.37 & - & - & - & - & - & - \\
\hline & $\mathrm{NC}$ & 1 & 0.18 & 1 & 0.16 & - & - & 1 & 0.37 & - & - & - & - & - & - \\
\hline XXVIII & $\Sigma$ & 1 & 0.18 & 1 & 0.16 & - & - & 1 & 0.37 & - & - & - & - & - & - \\
\hline & $\mathrm{NC}$ & 1 & 0.18 & 1 & 0.16 & - & - & 1 & 0.37 & - & - & - & - & - & - \\
\hline XXIX & $\Sigma$ & 3 & 0.54 & 3 & 0.49 & - & - & 3 & 1.10 & - & - & - & - & - & - \\
\hline & $\mathrm{NC}$ & 3 & 0.54 & 3 & 0.49 & - & - & 3 & 1.10 & - & - & - & - & - & - \\
\hline$\overline{X X X}$ & $\Sigma$ & 2 & 0.36 & 2 & 0.33 & - & - & 1 & 0.37 & - & - & - & - & 1 & 0.66 \\
\hline & NC & 2 & 0.36 & 2 & 0.33 & - & - & 1 & 0.37 & - & - & - & - & 1 & 0.66 \\
\hline XXXI & $\Sigma$ & 1 & 0.18 & 1 & 0.16 & - & - & 1 & 0.37 & - & - & - & - & - & - \\
\hline & $\mathrm{NC}$ & 1 & 0.18 & 1 & 0.16 & - & - & 1 & 0.37 & - & - & - & - & - & - \\
\hline XXXII & $\Sigma$ & 2 & 0.36 & 2 & 0.33 & - & - & 2 & 0.74 & - & - & - & - & - & - \\
\hline & $\mathrm{NC}$ & 2 & 0.36 & 2 & 0.33 & - & - & 2 & 0.74 & - & - & - & - & - & - \\
\hline XXXIII & $\Sigma$ & 2 & 0.36 & 2 & 0.33 & - & - & - & - & 1 & 3.23 & - & - & 1 & 0.66 \\
\hline & $\mathrm{NC}$ & 2 & 0.36 & 2 & 0.33 & - & - & - & - & 1 & 3.23 & - & - & 1 & 0.66 \\
\hline XXXIV & $\Sigma$ & 1 & 0.18 & 1 & 0.16 & - & - & - & - & - & - & - & - & 1 & 0.66 \\
\hline & $\mathrm{NC}$ & 1 & 0.18 & 1 & 0.16 & - & - & - & - & - & - & - & - & 1 & 0.66 \\
\hline $\mathrm{XXXV}$ & $\Sigma$ & 6 & 1.08 & 6 & 0.98 & - & - & - & - & - & - & - & - & 6 & 3.97 \\
\hline & Cluster 52 & 2 & 0.36 & 2 & 0.33 & - & - & - & - & - & - & - & - & 2 & 1.32 \\
\hline & Cluster 53 & 3 & 0.54 & 3 & 0.49 & - & - & - & - & - & - & - & - & 3 & 1.99 \\
\hline & $\mathrm{NC}$ & 1 & 0.18 & 1 & 0.16 & - & - & - & - & - & - & - & - & 1 & 0.66 \\
\hline $\mathrm{XXXVI}$ & $\Sigma$ & 1 & 0.18 & 1 & 0.16 & - & - & - & - & - & - & - & - & 1 & 0.66 \\
\hline & $\mathrm{NC}$ & 1 & 0.18 & 1 & 0.16 & - & - & - & - & - & - & - & - & 1 & 0.66 \\
\hline XXXVII & $\Sigma$ & 9 & 1.63 & 10 & 1.64 & - & - & - & - & - & - & - & - & 10 & 6.62 \\
\hline & Cluster 54 & 6 & 1.08 & 7 & 1.15 & - & - & - & - & - & - & - & - & 7 & 4.64 \\
\hline & $\mathrm{NC}$ & 3 & 0.54 & 3 & 0.49 & - & - & - & - & - & - & - & - & 3 & 1.99 \\
\hline XXXVIII & $\Sigma$ & 8 & 1.45 & 8 & 1.31 & - & - & - & - & - & - & - & - & 8 & 5.30 \\
\hline & Cluster 55 & 2 & 0.36 & 2 & 0.33 & - & - & - & - & - & - & - & - & 2 & 1.32 \\
\hline & Cluster 56 & 6 & 1.08 & 6 & 0.98 & - & - & - & - & - & - & - & - & 6 & 3.97 \\
\hline XXXIX & $\Sigma$ & 1 & 0.18 & 1 & 0.16 & - & - & - & - & - & - & - & - & 1 & 0.66 \\
\hline & $\mathrm{NC}$ & 1 & 0.18 & 1 & 0.16 & - & - & - & - & - & - & - & - & 1 & 0.66 \\
\hline$X L$ & $\Sigma$ & 1 & 0.18 & 1 & 0.16 & - & - & - & - & - & - & - & - & 1 & 0.66 \\
\hline & $\mathrm{NC}$ & 1 & 0.18 & 1 & 0.16 & - & - & - & - & - & - & - & - & 1 & 0.66 \\
\hline XLI & $\Sigma$ & 5 & 0.90 & 5 & 0.82 & - & - & 5 & 1.84 & - & - & - & - & - & - \\
\hline & Cluster 57 & 4 & 0.72 & 4 & 0.66 & - & - & 4 & 1.47 & - & - & - & - & - & - \\
\hline
\end{tabular}

a Taxa are genetically related to distance $\left(d_{i j}>0.1175\right)$ and each taxon displays clustered isolates and/or non-clustered isolates. ${ }^{\mathrm{b}}$ Cluster comprised two or more bacterial isolates interpreted as identical or highly related isolates/strains $\left(0.0551>d_{i j} \geq 0\right)$. ${ }^{\mathrm{c}} \mathrm{NC}$ : non-clustered isolates or strains $\left(0.0551<d_{i j} \leq 0.3810\right) .{ }^{d}$ Number and percentage of strains per Cluster. strain refers to a collection of isolates of the same species that are genetically indistinguishable. e Number and percentage of isolates per Cluster. an isolate is defined as a clone collected independently of other isolates. Two independently collected isolates may be completely unrelated (different strains) or genetically indistinguishable (same strain). ${ }^{f}$ Number and percentage of isolates per bacterial population (A, $B, C, D$ and $E)$. 
Supplemental Table 2 - Interpretation of UPGMA dendrogram generated from the genetic distance matrix (Nei, 1972) and the genetic interpretation of the MLEE patterns of $S$. aureus (cont.)

\begin{tabular}{|c|c|c|c|c|c|c|c|c|c|c|c|c|c|c|c|}
\hline \multirow[t]{3}{*}{ Taxon $^{\text {a }}$} & \multirow{3}{*}{$\begin{array}{l}\text { Cluster }^{b} \\
\text { or NC }{ }^{\mathrm{c}} \\
\text { Isolate }\end{array}$} & \multicolumn{2}{|c|}{ Strain $^{d}$} & \multicolumn{2}{|c|}{ Isolate ${ }^{e}$} & \multicolumn{10}{|c|}{ Bacterial populations $^{f}$} \\
\hline & & \multirow{2}{*}{$\begin{array}{l}n \\
1\end{array}$} & \multirow{2}{*}{$\begin{array}{c}\% \\
0.18\end{array}$} & \multirow{2}{*}{$\begin{array}{l}n \\
1\end{array}$} & \multirow{2}{*}{$\begin{array}{c}\% \\
0.16\end{array}$} & \multicolumn{2}{|c|}{$\mathrm{A}(n$ and $\%)$} & \multicolumn{2}{|c|}{$\mathrm{B}(n$ and $\%)$} & \multicolumn{2}{|c|}{$\mathrm{C}(n$ and $\%)$} & \multicolumn{2}{|c|}{$\mathrm{D}(n$ and $\%)$} & \multicolumn{2}{|c|}{$\mathrm{E}(n$ and $\%)$} \\
\hline & & & & & & - & - & 1 & 0.37 & - & - & - & - & - & - \\
\hline \multirow[t]{3}{*}{ XLII } & $\Sigma$ & 7 & 1.27 & 7 & 1.15 & - & - & 7 & 2.57 & - & - & - & - & - & - \\
\hline & Cluster 58 & 6 & 1.08 & 6 & 0.98 & - & - & 6 & 2.21 & - & - & - & - & - & - \\
\hline & $\mathrm{NC}$ & 1 & 0.18 & 1 & 0.16 & - & - & 1 & 0.37 & - & - & - & - & - & - \\
\hline \multirow[t]{2}{*}{ XLIII } & $\Sigma$ & 1 & 0.18 & 1 & 0.16 & - & - & 1 & 0.37 & - & - & - & - & - & - \\
\hline & $\mathrm{NC}$ & 1 & 0.18 & 1 & 0.16 & - & - & 1 & 0.37 & - & - & - & - & - & - \\
\hline \multirow[t]{2}{*}{ XLIV } & $\Sigma$ & 1 & 0.18 & 1 & 0.16 & - & - & 1 & 0.37 & - & - & - & - & - & - \\
\hline & NC & 1 & 0.18 & 1 & 0.16 & - & - & 1 & 0.37 & - & - & - & - & - & - \\
\hline \multirow[t]{2}{*}{$\mathrm{XLV}$} & $\Sigma$ & 1 & 0.18 & 1 & 0.16 & - & - & 1 & 0.37 & - & - & - & - & - & - \\
\hline & $\mathrm{NC}$ & 1 & 0.18 & 1 & 0.16 & - & - & 1 & 0.37 & - & - & - & - & - & - \\
\hline XLVI & $\Sigma$ & 3 & 0.54 & 3 & 0.49 & - & - & - & - & - & - & - & - & 3 & 1.99 \\
\hline & $\mathrm{NC}$ & 3 & 0.54 & 3 & 0.49 & - & - & - & - & - & - & - & - & 3 & 1.99 \\
\hline XLVII & $\Sigma$ & 1 & 0.18 & 1 & 0.16 & - & - & - & - & - & - & - & - & 1 & 0.66 \\
\hline & $\mathrm{NC}$ & 1 & 0.18 & 1 & 0.16 & - & - & - & - & - & - & - & - & 1 & 0.66 \\
\hline XLVIII & $\Sigma$ & 1 & 0.18 & 1 & 0.16 & - & - & - & - & - & - & - & - & 1 & 0.66 \\
\hline & $\mathrm{NC}$ & 1 & 0.18 & 1 & 0.16 & - & - & - & - & - & - & - & - & 1 & 0.66 \\
\hline XLIX & $\Sigma$ & 1 & 0.18 & 1 & 0.16 & - & - & - & - & - & - & - & - & 1 & 0.66 \\
\hline & NC & 1 & 0.18 & 1 & 0.16 & - & - & - & - & - & - & - & - & 1 & 0.66 \\
\hline $\mathrm{L}$ & $\Sigma$ & 30 & 5.42 & 30 & 4.92 & - & - & 16 & 5.88 & - & - & - & - & 14 & 9.27 \\
\hline & Cluster 59 & 7 & 1.27 & 7 & 1.15 & - & - & - & - & - & - & - & - & 7 & 4.64 \\
\hline & Cluster 60 & 8 & 1.45 & 8 & 1.31 & - & - & 4 & 1.47 & - & - & - & - & 4 & 2.65 \\
\hline & Cluster 61 & 7 & 1.27 & 7 & 1.15 & - & - & 7 & 2.57 & - & - & - & - & - & - \\
\hline & Cluster 62 & 3 & 0.54 & 3 & 0.49 & - & - & 2 & 0.74 & - & - & - & - & 1 & 0.66 \\
\hline & Cluster 63 & 2 & 0.36 & 2 & 0.33 & - & - & 2 & 0.74 & - & - & - & - & - & - \\
\hline & $\mathrm{NC}$ & 3 & 0.54 & 3 & 0.49 & - & - & 1 & 0.37 & - & - & - & - & 2 & 1.32 \\
\hline LI & $\Sigma$ & 2 & 0.36 & 2 & 0.33 & - & - & - & - & - & - & - & - & 2 & 1.32 \\
\hline & Cluster 64 & 2 & 0.36 & 2 & 0.33 & - & - & - & - & - & - & - & - & 2 & 1.32 \\
\hline LII & $\Sigma$ & 4 & 0.72 & 4 & 0.66 & - & - & 4 & 1.47 & - & - & - & - & - & - \\
\hline & Cluster 65 & 2 & 0.36 & 2 & 0.33 & - & - & 2 & 0.74 & - & - & - & - & - & - \\
\hline & $\mathrm{NC}$ & 2 & 0.36 & 2 & 0.33 & - & - & 2 & 0.74 & - & - & - & - & - & - \\
\hline LIII & $\Sigma$ & 5 & 0.90 & 5 & 0.82 & - & - & - & - & - & - & - & - & 5 & 3.31 \\
\hline & Cluster 66 & 2 & 0.36 & 2 & 0.33 & - & - & - & - & - & - & - & - & 2 & 1.32 \\
\hline & Cluster 67 & 2 & 0.36 & 2 & 0.33 & - & - & - & - & - & - & - & - & 2 & 1.32 \\
\hline & $\mathrm{NC}$ & 1 & 0.18 & 1 & 0.16 & - & - & - & - & - & - & - & - & 1 & 0.66 \\
\hline LIV & $\Sigma$ & 1 & 0.18 & 1 & 0.16 & - & - & 1 & 0.37 & - & - & - & - & - & - \\
\hline & $\mathrm{NC}$ & 1 & 0.18 & 1 & 0.16 & - & - & 1 & 0.37 & - & - & - & - & - & - \\
\hline LV & $\Sigma$ & 1 & 0.18 & 1 & 0.16 & - & - & - & - & - & - & - & - & 1 & 0.66 \\
\hline & $\mathrm{NC}$ & 1 & 0.18 & 1 & 0.16 & - & - & - & - & - & - & - & - & 1 & 0.66 \\
\hline LVI & $\Sigma$ & 17 & 3.07 & 18 & 2.95 & - & - & 7 & 2.57 & - & - & - & - & 11 & 7.28 \\
\hline & Cluster 68 & 5 & 0.90 & 5 & 0.82 & - & - & - & - & - & - & - & - & 5 & 3.31 \\
\hline & Cluster 69 & 5 & 0.90 & 6 & 0.98 & - & - & 1 & 0.37 & - & - & - & - & 5 & 3.31 \\
\hline & Cluster 70 & 2 & 0.36 & 2 & 0.33 & - & - & 2 & 0.74 & - & - & - & - & - & - \\
\hline & Cluster 71 & 2 & 0.36 & 2 & 0.33 & - & - & 2 & 0.74 & - & - & - & - & - & - \\
\hline & $\mathrm{NC}$ & 3 & 0.54 & 3 & 0.49 & - & - & 2 & 0.74 & - & - & - & - & 1 & 0.66 \\
\hline LVII & $\Sigma$ & 18 & 3.25 & 19 & 3.11 & - & - & - & - & - & - & - & - & 19 & 12.58 \\
\hline
\end{tabular}

a Taxa are genetically related to distance $\left(d_{i j}>0.1175\right)$ and each taxon displays clustered isolates and/or non-clustered isolates. ${ }^{\mathrm{b}}$ Cluster comprised two or more bacterial isolates interpreted as identical or highly related isolates/strains $\left(0.0551>d_{i j} \geq 0\right) .{ }^{\mathrm{c}} \mathrm{NC}$ : non-clustered isolates or strains $\left(0.0551<d_{i j} \leq 0.3810\right) .{ }^{d}$ Number and percentage of strains per Cluster. strain refers to a collection of isolates of the same species that are genetically indistinguishable. ${ }^{e}$ Number and percentage of isolates per Cluster. an isolate is defined as a clone collected independently of other isolates. Two independently collected isolates may be completely unrelated (different strains) or genetically indistinguishable (same strain). ${ }^{\mathrm{f}}$ Number and percentage of isolates per bacterial population (A, $\mathrm{B}, \mathrm{C}, \mathrm{D}$ and $\mathrm{E})$. 
Supplemental Table 2 - Interpretation of UPGMA dendrogram generated from the genetic distance matrix (Nei, 1972) and the genetic interpretation of the MLEE patterns of $S$. aureus (cont.)

\begin{tabular}{|c|c|c|c|c|c|c|c|c|c|c|c|c|c|c|c|}
\hline \multirow[t]{3}{*}{ Taxon $^{\mathrm{a}}$} & \multirow{3}{*}{$\begin{array}{l}\text { Cluster }^{\text {b }} \\
\text { or NC }^{\text {c }}\end{array}$} & \multicolumn{2}{|c|}{ Strain $^{d}$} & \multicolumn{2}{|c|}{ Isolate ${ }^{e}$} & \multicolumn{10}{|c|}{ Bacterial populations $^{f}$} \\
\hline & & \multirow{2}{*}{$\begin{array}{l}n \\
3\end{array}$} & \multirow{2}{*}{$\begin{array}{c}\% \\
0.54\end{array}$} & \multirow{2}{*}{$\begin{array}{l}n \\
3\end{array}$} & \multirow{2}{*}{$\begin{array}{c}\% \\
0.49\end{array}$} & \multicolumn{2}{|c|}{$\mathrm{A}(n$ and $\%)$} & \multicolumn{2}{|c|}{$\mathrm{B}(n$ and $\%)$} & \multicolumn{2}{|c|}{$\mathrm{C}(n$ and $\%)$} & \multicolumn{2}{|c|}{$\mathrm{D}(n$ and $\%)$} & \multicolumn{2}{|c|}{$\mathrm{E}(n$ and $\%)$} \\
\hline & & & & & & - & - & - & - & - & - & - & - & 3 & 1.99 \\
\hline & Cluster 73 & 11 & 1.99 & 12 & 1.97 & - & - & - & - & - & - & - & - & 12 & 7.95 \\
\hline & Cluster 74 & 2 & 0.36 & 2 & 0.33 & - & - & - & - & - & - & - & - & 2 & 1.32 \\
\hline & $\mathrm{NC}$ & 2 & 0.36 & 2 & 0.33 & - & - & - & - & - & - & - & - & 2 & 1.32 \\
\hline \multirow[t]{2}{*}{ LVIII } & $\Sigma$ & 1 & 0.18 & 1 & 0.16 & - & - & - & - & - & - & - & - & 1 & 0.66 \\
\hline & $\mathrm{NC}$ & 1 & 0.18 & 1 & 0.16 & - & - & - & - & - & - & - & - & 1 & 0.66 \\
\hline \multirow[t]{3}{*}{ LIX } & $\Sigma$ & 3 & 0.54 & 3 & 0.49 & - & - & 1 & 0.37 & - & - & - & - & 2 & 1.32 \\
\hline & Cluster 75 & 2 & 0.36 & 2 & 0.33 & - & - & - & - & - & - & - & - & 2 & 1.32 \\
\hline & $\mathrm{NC}$ & 1 & 0.18 & 1 & 0.16 & - & - & 1 & 0.37 & - & - & - & - & - & - \\
\hline \multirow[t]{2}{*}{ LX } & $\Sigma$ & 3 & 0.54 & 4 & 0.66 & - & - & 4 & 1.47 & - & - & - & - & - & - \\
\hline & Cluster 76 & 3 & 0.54 & 4 & 0.66 & - & - & 4 & 1.47 & - & - & - & - & - & - \\
\hline \multirow{2}{*}{ LXI } & $\Sigma$ & 1 & 0.18 & 1 & 0.16 & - & - & 1 & 0.37 & - & - & - & - & - & - \\
\hline & $\mathrm{NC}$ & 1 & 0.18 & 1 & 0.16 & - & - & 1 & 0.37 & - & - & - & - & - & - \\
\hline LXII & & 4 & 0.72 & 6 & 0.98 & - & - & - & - & 6 & 19.35 & - & - & - & - \\
\hline & Cluster 77 & 1 & 0.18 & 3 & 0.49 & - & - & - & - & 3 & 9.68 & - & - & - & - \\
\hline & Cluster 78 & 2 & 0.36 & 2 & 0.33 & - & - & - & - & 2 & 6.45 & - & - & - & - \\
\hline & $\mathrm{NC}$ & 1 & 0.18 & 1 & 0.16 & - & - & - & - & 1 & 3.23 & - & - & - & - \\
\hline LXIII & $\Sigma$ & 3 & 0.54 & 3 & 0.49 & - & - & 3 & 1.10 & - & - & - & - & - & - \\
\hline & $\mathrm{NC}$ & 3 & 0.54 & 3 & 0.49 & - & - & 3 & 1.10 & - & - & - & - & - & - \\
\hline LXIV & $\Sigma$ & 19 & 3.44 & 19 & 3.11 & 6 & 4.55 & 13 & 4.78 & - & - & - & - & - & - \\
\hline & Cluster 79 & 2 & 0.36 & 2 & 0.33 & - & - & 2 & 0.74 & - & - & - & - & - & - \\
\hline & Cluster 80 & 2 & 0.36 & 2 & 0.33 & - & - & 2 & 0.74 & - & - & - & - & - & - \\
\hline & Cluster 81 & 3 & 0.54 & 3 & 0.49 & - & - & 3 & 1.10 & - & - & - & - & - & - \\
\hline & Cluster 82 & 2 & 0.36 & 2 & 0.33 & - & - & 2 & 0.74 & - & - & - & - & - & - \\
\hline & Cluster 83 & 2 & 0.36 & 2 & 0.33 & - & - & 2 & 0.74 & - & - & - & - & - & - \\
\hline & Cluster 84 & 5 & 0.90 & 5 & 0.82 & 5 & 3.79 & - & - & - & - & - & - & - & - \\
\hline & $\mathrm{NC}$ & 3 & 0.54 & 3 & 0.49 & 1 & 0.76 & 2 & 0.74 & - & - & - & - & - & - \\
\hline$\overline{L X V}$ & $\Sigma$ & 3 & 0.54 & 3 & 0.49 & - & - & 3 & 1.10 & - & - & - & - & - & - \\
\hline & Cluster 85 & 2 & 0.36 & 2 & 0.33 & - & - & 2 & 0.74 & - & - & - & - & - & - \\
\hline & $\mathrm{NC}$ & 1 & 0.18 & 1 & 0.16 & - & - & 1 & 0.37 & - & - & - & - & - & - \\
\hline LXVI & $\Sigma$ & 8 & 1.45 & 8 & 1.31 & 8 & 6.06 & - & - & - & - & - & - & - & - \\
\hline & Cluster 86 & 2 & 0.36 & 2 & 0.33 & 2 & 1.52 & - & - & - & - & - & - & - & - \\
\hline & Cluster 87 & 2 & 0.36 & 2 & 0.33 & 2 & 1.52 & - & - & - & - & - & - & - & - \\
\hline & $\mathrm{NC}$ & 4 & 0.72 & 4 & 0.66 & 4 & 3.03 & - & - & - & - & - & - & - & - \\
\hline LXVII & $\Sigma$ & 4 & 0.72 & 4 & 0.66 & - & - & 4 & 1.47 & - & - & - & - & - & - \\
\hline & Cluster 88 & 4 & 0.72 & 4 & 0.66 & - & - & 4 & 1.47 & - & - & - & - & - & - \\
\hline LXVIII & $\Sigma$ & 1 & 0.18 & 1 & 0.16 & - & - & 1 & 0.37 & - & - & - & - & - & - \\
\hline & $\mathrm{NC}$ & 1 & 0.18 & 1 & 0.16 & - & - & 1 & 0.37 & - & - & - & - & - & - \\
\hline LXIX & $\Sigma$ & 3 & 0.54 & 3 & 0.49 & - & - & 3 & 1.10 & - & - & - & - & - & - \\
\hline & Cluster 89 & 2 & 0.36 & 2 & 0.33 & - & - & 2 & 0.74 & - & - & - & - & - & - \\
\hline & $\mathrm{NC}$ & 1 & 0.18 & 1 & 0.16 & - & - & 1 & 0.37 & - & - & - & - & - & - \\
\hline LXX & $\Sigma$ & 1 & 0.18 & 1 & 0.16 & - & - & 1 & 0.37 & - & - & - & - & - & - \\
\hline & $\mathrm{NC}$ & 1 & 0.18 & 1 & 0.16 & - & - & 1 & 0.37 & - & - & - & - & - & - \\
\hline LXXI & $\Sigma$ & 1 & 0.18 & 1 & 0.16 & 1 & 0.76 & - & - & - & - & - & - & - & - \\
\hline & $\mathrm{NC}$ & 1 & 0.18 & 1 & 0.16 & 1 & 0.76 & - & - & - & - & - & - & - & - \\
\hline
\end{tabular}

a Taxa are genetically related to distance $\left(d_{i j}>0.1175\right)$ and each taxon displays clustered isolates and/or non-clustered isolates. ${ }^{\mathrm{b}}$ Cluster comprised two or more bacterial isolates interpreted as identical or highly related isolates/strains $\left(0.0551>d_{i j} \geq 0\right)$. ${ }^{\mathrm{c}} \mathrm{NC}$ : non-clustered isolates or strains $\left(0.0551<d_{i j} \leq 0.3810\right) .{ }^{\mathrm{d}}$ Number and percentage of strains per Cluster. strain refers to a collection of isolates of the same species that are genetically indistinguishable. ${ }^{e}$ Number and percentage of isolates per Cluster. an isolate is defined as a clone collected independently of other isolates. Two independently collected isolates may be completely unrelated (different strains) or genetically indistinguishable (same strain). ${ }^{f}$ Number and percentage of isolates per bacterial population (A, $B, C, D$ and $E)$. 
Supplemental Table 2 - Interpretation of UPGMA dendrogram generated from the genetic distance matrix (Nei, 1972) and the genetic interpretation of the MLEE patterns of $S$. aureus (cont.)

\begin{tabular}{|c|c|c|c|c|c|c|c|c|c|c|c|c|c|c|c|}
\hline \multirow{3}{*}{$\begin{array}{l}\text { Taxon }^{\mathrm{a}} \\
\mathrm{LXXII}\end{array}$} & \multirow{3}{*}{$\begin{array}{l}\text { Cluster }^{\mathrm{b}} \\
\text { or NC }^{\mathrm{c}} \\
\sum\end{array}$} & \multicolumn{2}{|c|}{ Strain $^{d}$} & \multicolumn{2}{|c|}{ Isolate $^{e}$} & \multicolumn{10}{|c|}{ Bacterial populations $^{f}$} \\
\hline & & \multirow{2}{*}{$\begin{array}{c}n \\
1\end{array}$} & \multirow{2}{*}{$\begin{array}{c}\% \\
0.18\end{array}$} & \multirow{2}{*}{$\frac{n}{1}$} & \multirow{2}{*}{$\begin{array}{c}\% \\
0.16\end{array}$} & \multicolumn{2}{|c|}{$\mathrm{A}(n$ and $\%)$} & \multicolumn{2}{|c|}{$\mathrm{B}(n$ and $\%)$} & \multicolumn{2}{|c|}{$\mathrm{C}(n$ and $\%)$} & \multicolumn{2}{|c|}{$\mathrm{D}(n$ and $\%)$} & \multicolumn{2}{|c|}{$\mathrm{E}(n$ and $\%)$} \\
\hline & & & & & & - & - & - & - & 1 & 3.23 & - & - & - & - \\
\hline & $\mathrm{NC}$ & 1 & 0.18 & 1 & 0.16 & - & - & - & - & 1 & 3.23 & - & - & - & - \\
\hline \multirow[t]{2}{*}{ LXXIII } & $\Sigma$ & 3 & 0.54 & 3 & 0.49 & - & - & - & - & - & - & - & - & 3 & 1.99 \\
\hline & $\mathrm{NC}$ & 3 & 0.54 & 3 & 0.49 & - & - & - & - & - & - & - & - & 3 & 1.99 \\
\hline \multirow[t]{2}{*}{$\overline{\text { LXXIV }}$} & $\Sigma$ & 1 & 0.18 & 1 & 0.16 & - & - & 1 & 0.37 & - & - & - & - & - & - \\
\hline & NC & 1 & 0.18 & 1 & 0.16 & - & - & 1 & 0.37 & - & - & - & - & - & - \\
\hline \multirow[t]{2}{*}{ LXXV } & $\sum$ & 1 & 0.18 & 1 & 0.16 & - & - & 1 & 0.37 & - & - & - & - & - & - \\
\hline & $\mathrm{NC}$ & 1 & 0.18 & 1 & 0.16 & - & - & 1 & 0.37 & - & - & - & - & - & - \\
\hline \multirow[t]{2}{*}{$\overline{L X X V I}$} & $\Sigma$ & 1 & 0.18 & 1 & 0.16 & 1 & 0.76 & - & - & - & - & - & - & - & - \\
\hline & $\mathrm{NC}$ & 1 & 0.18 & 1 & 0.16 & 1 & 0.76 & - & - & - & - & - & - & - & - \\
\hline \multirow[t]{2}{*}{ LXXVII } & $\Sigma$ & 1 & 0.18 & 1 & 0.16 & - & - & 1 & 0.37 & - & - & - & - & - & - \\
\hline & $\mathrm{NC}$ & 1 & 0.18 & 1 & 0.16 & - & - & 1 & 0.37 & - & - & - & - & - & - \\
\hline \multirow[t]{2}{*}{ LXXVIII } & & 1 & 0.18 & 1 & 0.16 & - & - & - & - & - & - & 1 & 4.17 & - & - \\
\hline & $\mathrm{NC}$ & 1 & 0.18 & 1 & 0.16 & - & - & - & - & - & - & 1 & 4.17 & - & - \\
\hline \multirow[t]{3}{*}{ LXXIX } & $\Sigma$ & 2 & 0.36 & 7 & 1.15 & - & - & - & - & 7 & 22.58 & - & - & - & - \\
\hline & Cluster 90 & 1 & 0.18 & 5 & 0.82 & - & - & - & - & 5 & 16.13 & - & - & - & - \\
\hline & Cluster 91 & 1 & 0.18 & 2 & 0.33 & - & - & - & - & 2 & 6.45 & - & - & - & - \\
\hline \multirow[t]{2}{*}{ LXXX } & $\Sigma$ & 1 & 0.18 & 1 & 0.16 & - & - & - & - & - & - & - & - & 1 & 0.66 \\
\hline & $\mathrm{NC}$ & 1 & 0.18 & 1 & 0.16 & - & - & - & - & - & - & - & - & 1 & 0.66 \\
\hline
\end{tabular}

a Taxa are genetically related to distance $\left(d_{i j}>0.1175\right)$ and each taxon displays clustered isolates and/or non-clustered isolates. ${ }^{\mathrm{b}}$ Cluster comprised two or more bacterial isolates interpreted as identical or highly related isolates/strains $\left(0.0551>d_{i j} \geq 0\right) .{ }^{\mathrm{c}} \mathrm{NC}$ : non-clustered isolates or strains $\left(0.0551<d_{i j} \leq 0.3810\right) .{ }^{d}$ Number and percentage of strains per Cluster. strain refers to a collection of isolates of the same species that are genetically indistinguishable. ${ }^{e}$ Number and percentage of isolates per Cluster. an isolate is defined as a clone collected independently of other isolates. Two independently collected isolates may be completely unrelated (different strains) or genetically indistinguishable (same strain). ${ }^{f}$ Number and percentage of isolates per bacterial population (A, $\mathrm{B}, \mathrm{C}, \mathrm{D}$ and $\mathrm{E})$. 